\title{
WATER LEVELS IN THE YUCCA MOUNTAIN AREA, NEVADA, 1993
}

U.S. GEOLOGICAL SURVEY

USES-OFR--95-159

Open-File Report 95-159

\author{
RECEIVED \\ JUL 221996 \\ OSTI
}

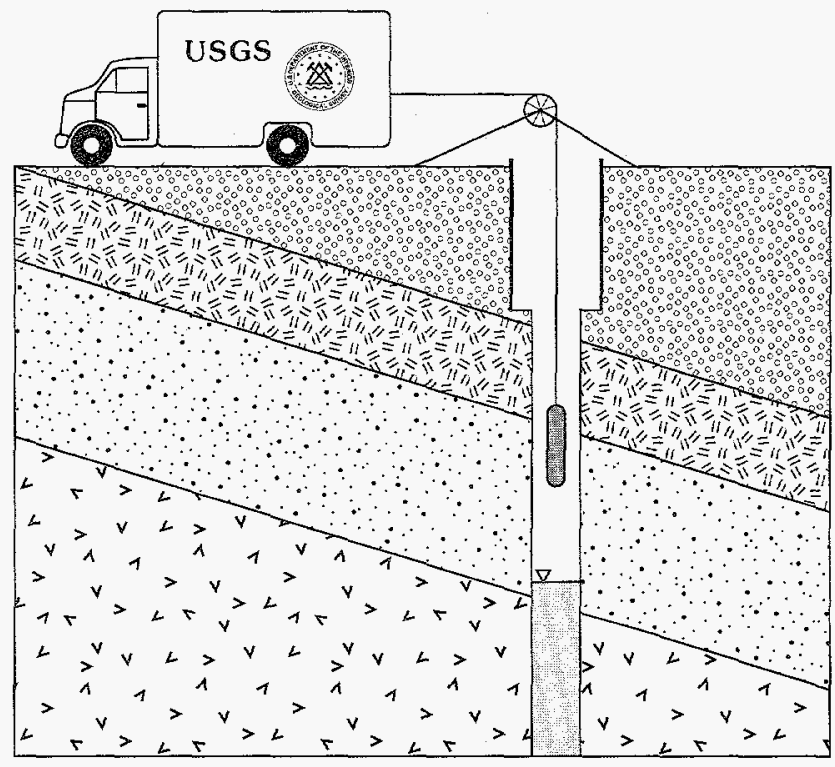

Prepared in cooperation with the NEVADA OPERATIONS OFFICE, U.S. DEPARTMENT OF ENERGY, under Interagency Agreement DE-AI08-92NV10874

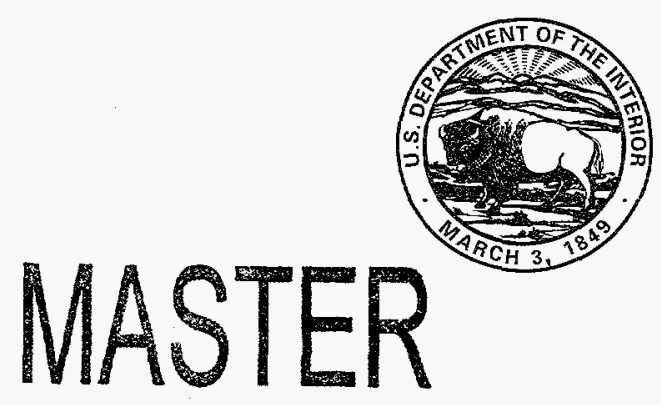




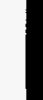




\section{WATER LEVELS IN THE YUCCA MOUNTAIN AREA, NEVADA, 1993}

by Patrick Tucci, Robert L. Goemaat, and Douglas J. Burkhardt

\section{U.S. GEOLOGICAL SURVEY}

Open-File Report 95-159

Prepared in cooperation with the

NEVADA OPERATIONS OFFICE,

U.S. DEPARTMENT OF ENERGY, under

Interagency Agreement DE-Al08-92NV10874

Denver, Colorado

1996 


\title{
U.S. DEPARTMENT OF THE INTERIOR BRUCE BABBITT, Secretary
}

\author{
U.S. GEOLOGICAL SURVEY
}

Gordon P. Eaton, Director

\section{DISCLAIMER}

\begin{abstract}
This report was prepared as an account of work sponsored by an agency of the United States Government. Neither the United States Government nor any agency thereof, nor any of their employees, makes any warranty, express or implied, or assumes any legal liability or responsibility for the accuracy, completeness, or usefulness of any information, apparatus, product, or process disclosed, or represents that its use would not infringe privately owned rights. Reference herein to any specific commercial product, process, or service by trade name, trademark, manufacturer, or otherwise does not necessarily constitute or imply its endorsement, recommendation, or favoring by the United States Government or any agency thereof. The views and opinions of authors expressed herein do not necessarily state or reflect those of the United States Government or any agency thereof.
\end{abstract}

The use of trade, product, industry, or firm names is for descriptive purposes only and does not imply endorsement by the U.S. Government.

For additional information write to: Chief, Earth Science Investigations Program

Yucca Mountain Project Branch U.S. Geological Survey

Box 25046, MS 421

Denver Federal Center

Denver, CO 80225
Copies of this report can be purchased from: U.S. Geological Survey Information Services

Box 25286

Denver Federal Center

Denver, CO 80225 


\section{DISCLAIMER}

Portions of this document may be illegible in electronic image products. Images are produced from the best available original document. 



\section{CONTENTS}

Abstract

Introduction

Well designations

Data-collection system

Periodic measurements

Corrections and adjustments to manual measurements

Mechanical stretch

Thermal expansion

Borehole-deviation correction

Water-level altitudes

Example calculation

Precision and accuracy

Hourly measurements

Equipment

Transducers

Data loggers

Processing and adjustments

Conversion to water-level altitude

Quality assurance

Onsite procedures

Office processing and review

Well data and water levels

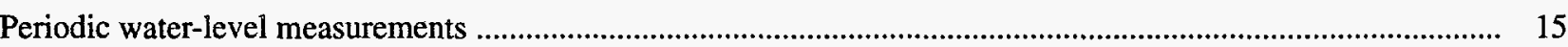

Well USW WT-1

Well UE-25 WT \#4

Well UE-25 WT \#6

Well USW WT-7

Well USW WT-10

Well UE-25 WT \#12

Well UE-25 WT \#14

Well UE-25 WT \#15

Well UE-25 WT \#16

Well UE-25 WT \#17

Well UE-25 WT \#18

Well UE-25b \#1

Well USW VH-1

Well USW G-2

Well J-11

Well J-12

Well J-13

Hourly water-level measurements .

Well USW WT-2

Well UE-25 WT \#3

Well USW WT-11

Well UE-25 WT \#13

Well UE-25p \#1

Well USW G-3

Well USW H-1

Well USW H-3

Well USW H-4

Well USW H-5

Well USW H-6

References cited 


\section{FIGURES}

1. Location of Yucca Mountain area and location of wells ................................................................................

2-36. Hydrographs showing water-level altitudes, 1993, for:

2. Well USW WT-1

3. Well UE-25 WT \#4

4. Well UE-25 WT \#6

5. Well USW WT-7

6. Well USW WT-10.

7. Well UE-25 WT \#12

8. Well UE-25 WT \#14

9. Well UE-25 WT \#15

10. Well UE-25 WT \#16

11. Well UE-25 WT \#17

12. Well UE-25 WT \#18

13. Well UE-25b \#1, upper interval..

14. Well USW VH-1

15. Well USW G-2

16. Well J-11

17. Well J-12

18. Well J-13

19. Well USW WT-2

20. Well UE-25 WT \#3

21. Well USW WT-11.

22. Well UE-25 WT \#13

23. Well UE-25p \#1

24. Well USW G-3

25. Well USW H-1, tube 1

26. Well USW H-1, tube 2

27. Well USW H-1, tube 3

28. Well USW H-1, tube 4

29. Well USW H-3, upper interval

30. Well USW H-3, lower interval

31. Well USW H-4, upper interval

32. Well USW H-4, lower interval

33. Well USW H-5, upper interval

34. Well USW H-5, lower interval

35. Well USW H-6, upper interval

36. Well USW H-6, lower interval

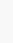
23

\section{TABLES}

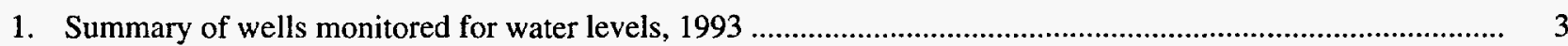

2. Corrections applicable to steel tapes used for measuring water levels, 1993, in the vicinity of Yucca Mountain

3. Mechanical stretch and thermal expansion equation variable values for steel tapes used in the vicinity of Yucca Mountain....

4-20. Measured water-level altitudes and yearly mean water-level altitude, 1993, for:
4. Well USW WT-1
5. Well UE-25 WT \#4
6. Well UE-25 WT \#6
7. Well USW WT-7
8. Well USW WT-10.
9. Well UE-25 WT \#12. 


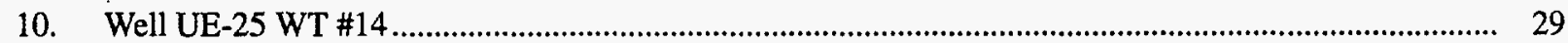

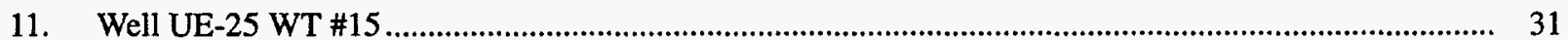

12. Well UE-25 WT \#16

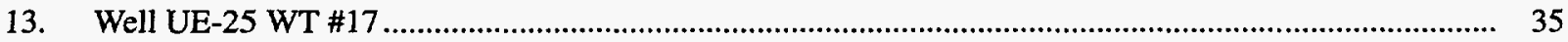

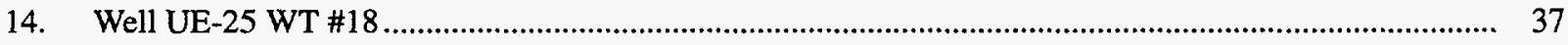

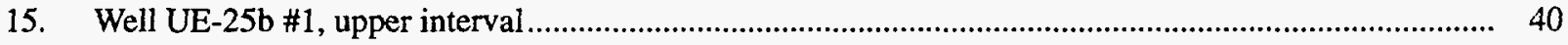

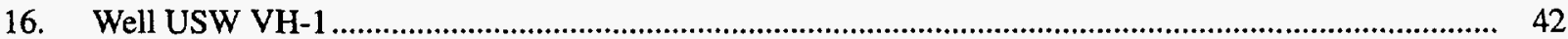

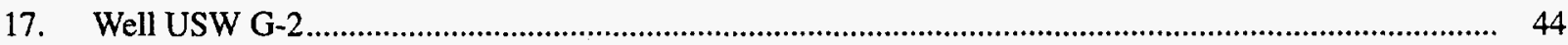

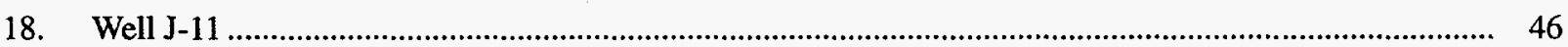

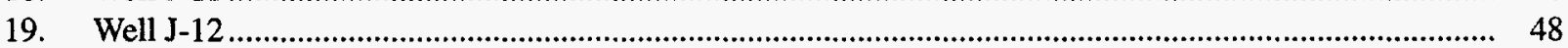

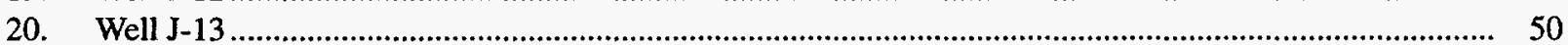

21-26. Mean monthly water-level altitudes, 1993, for:

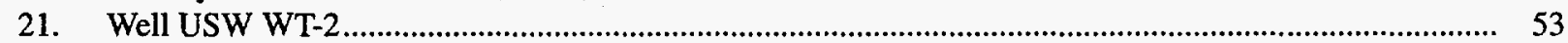

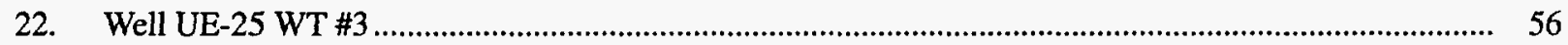

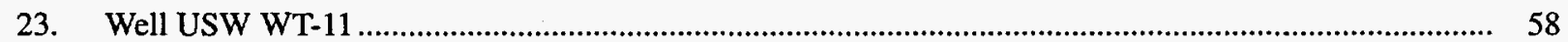

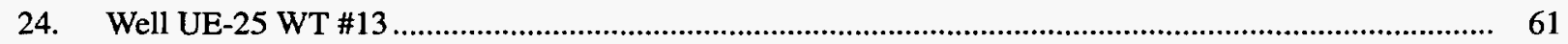

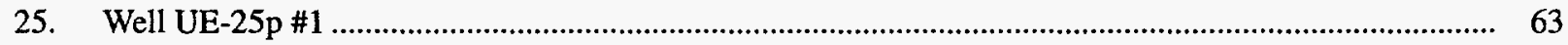

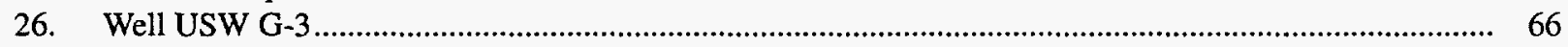

27. Measured water-level altitudes and yearly mean water-level altitude, 1993, for well H1, tube 1 ...................... 70

28-38. Mean monthly water-level altitudes, 1993, for:

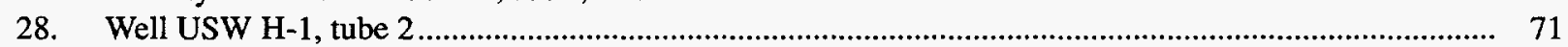

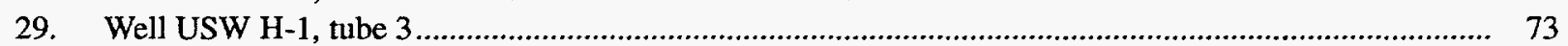

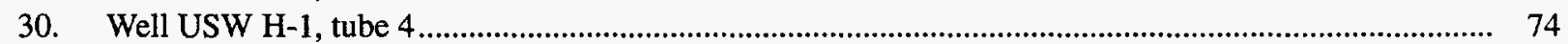

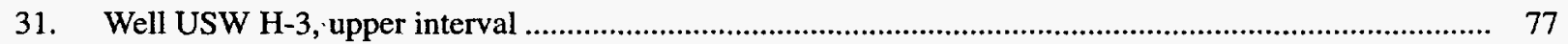

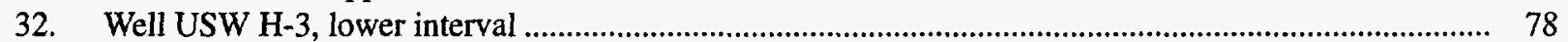

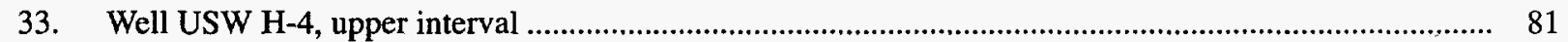

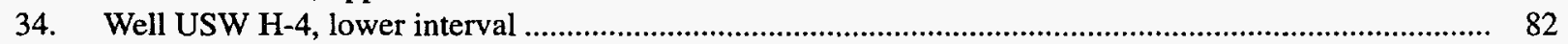

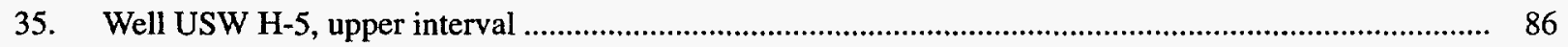

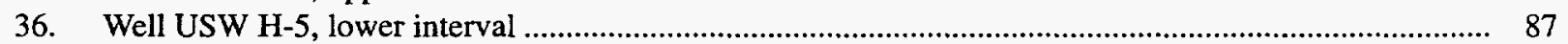

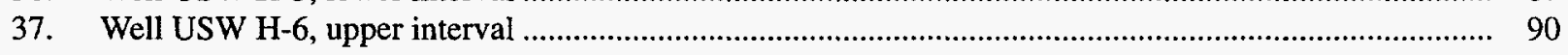

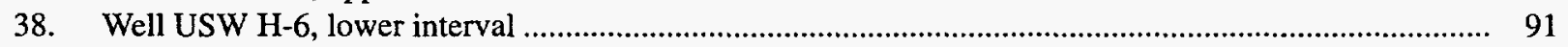

\section{CONVERSION FACTORS AND VERTICAL DATUM}

\begin{tabular}{rll}
\hline Multiply & By & To obtain \\
& & \\
cubic meter $\left(\mathrm{m}^{3}\right)$ & 264.2 & gallon \\
milometer $(\mathrm{km})$ & 0.6214 & mile \\
$\operatorname{liter}(\mathrm{L})$ & 0.03531 & cubic foot \\
foot & inch \\
millimeter $(\mathrm{mm})$ & 3.281 & kilograms per square meter \\
pounds per square inch $(\mathrm{psi})$ & 703.1 & square mile \\
square kilometer $\left(\mathrm{km}^{2}\right)$ & 0.3861 & \\
\hline
\end{tabular}

Sea level: In this report "sea level" refers to the National Geodetic Vertical Datum of 1929 (NGVD of 1929)-a geodetic datum derived from a general adjustment of the first-order level nets of both the United States and Canada, formerly called Sea Level Datum of 1929. 



\title{
Water Levels in the Yucca Mountain Area, Nevada, 1993
}

\author{
By Patrick Tucci, Robert L. Goemaat, and Douglas J. Burkhardt
}

\begin{abstract}
Water levels were monitored in 28 wells in the Yucca Mountain area, Nevada, during 1993. Seventeen wells were monitored periodically, generally on a monthly basis, and 11 wells representing 18 intervals were monitored hourly. All wells monitor water levels in Tertiary volcanic rocks, except one that monitors water levels in Paleozoic carbonate rocks. Water levels were measured using calibrated steel tapes and pressure transducers; steel-tape measurements were corrected for mechanical stretch, thermal expansion, and borehole deviation to obtain precise water-level altitudes.

Water-level altitudes in the Tertiary volcanic rocks ranged from about 728 meters above sea level east of Yucca Mountain to about 1,034 meters above sea level north of Yucca Mountain. Water-level altitudes in the well monitoring the Paleozoic carbonate rocks varied between 752 and 753 meters above sea level during 1993. Water levels were an average of about 0.04 meter lower than 1992 water levels. All data were acquired in accordance with a quality-assurance program to support the reliability of the data.
\end{abstract}

\section{INTRODUCTION}

The Yucca Mountain area is being evaluated by the U.S. Department of Energy for suitability to store high-level nuclear waste in a mined, underground repository. A $150-\mathrm{km}^{2}$ area located about $150 \mathrm{~km}$ northwest of Las Vegas in southern Nevada is being studied extensively (fig. 1). Water levels in selected wells have been measured periodically since 1981, and have been measured on an hourly or more frequent basis since 1983, to gain a better understanding of the ground-water flow system in the area. Water levels will be used to determine the direction and rate of ground-water flow and to estimate hydraulic parameters of the flow system. In the Yucca Mountain area, the water table is in air-fall and ash-flow tuffs of Tertiary age. Saturated carbonate rocks of Paleozoic age underlie the Tertiary volcanic rocks. The terminology for stratigraphic units in this report follows Carr (1988), Carr and others (1986), Byers and others (1976), and Winograd and Thordarson (1975).

This report describes the equipment and methods used to collect and process water-level data, presents the data collected, and lists water-level altitudes for a network of 28 wells. The network has evolved into one that, in 1993, included 11 wells that were monitored hourly and 17 wells that were monitored periodically. Continuous water-level and fluid-pressure data were also collected at wells USW H-5, USW H-6, and UE-25p \#1, using analog-chart recorders to allow monitoring of fluctuations caused by earthquakes; however, these continuous data are not included in this report. All wells monitor water levels in the various Tertiary volcanic rocks that underlie the Yucca Mountain area, except well UE-25p \#1, which monitors water levels in the Paleozoic carbonate rocks that underlie the volcanic rocks. A summary of these wells is given in table 1 , and their locations are shown in figure 1.

Water levels are measured periodically, generally monthly, using calibrated steel tapes or a multiconductor cable. Water levels are also monitored hourly using pressure transducers and electronic data loggers. The transducer/data-logger systems are calibrated by recording transducer output at known depths of submergence. Water-level measurements are made to obtain depth-to-water information during calibration using transducers, calibrated steel tapes, or multiconductor cables. The manual water-level measurements are adjusted for thermal expansion, mechanical stretch, equipment calibration, and 


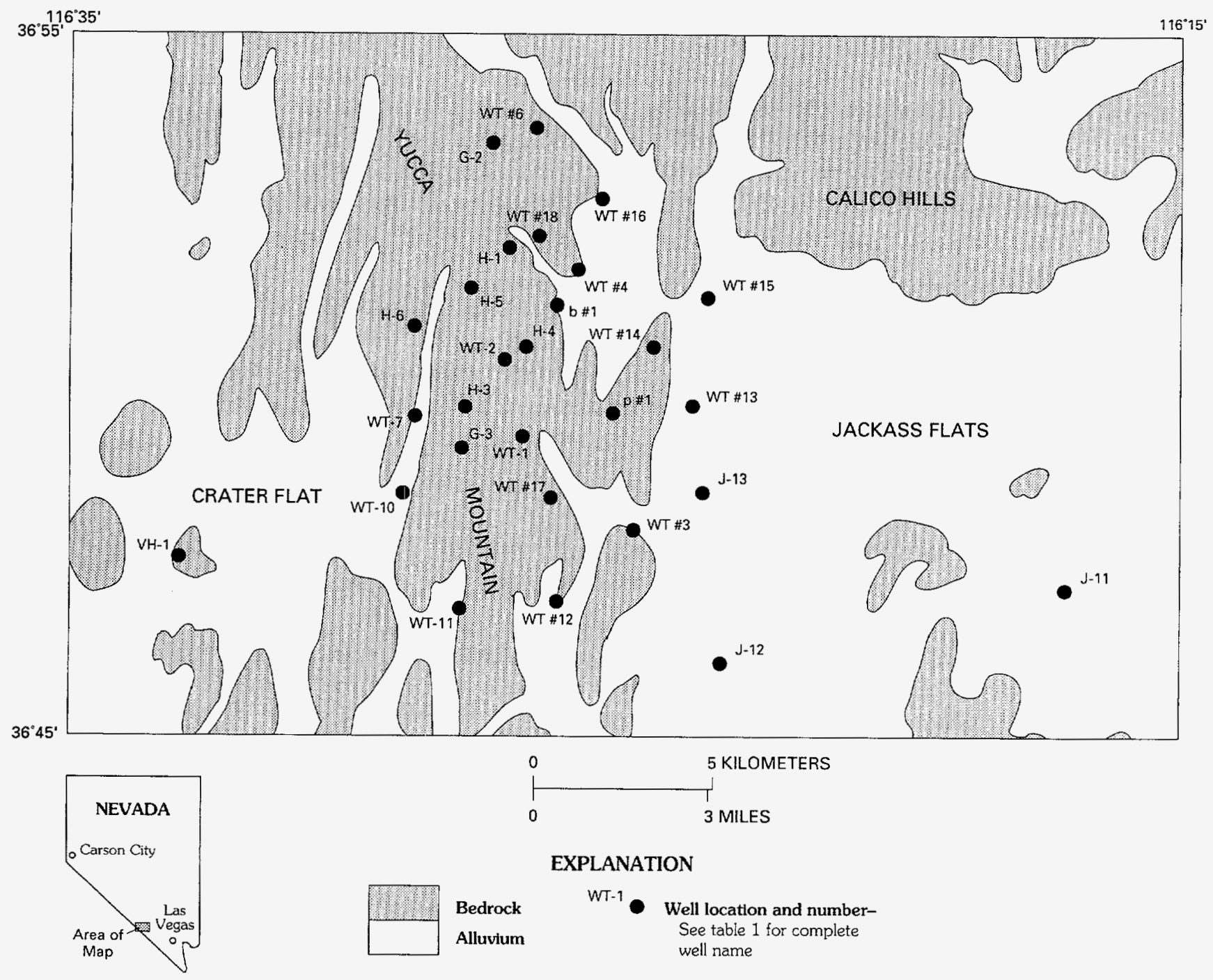

Figure 1. Location of Yucca Mountain area and location of wells. 
Table 1. Summary of wells monitored for water levels, 1993

[p, periodic measurements; $h$, hourly monitoring]

\begin{tabular}{|c|c|c|c|c|c|}
\hline \multirow[b]{2}{*}{ Well number } & \multirow[b]{2}{*}{$\begin{array}{l}\text { Drilled } \\
\text { depth } \\
\text { (meters) }\end{array}$} & \multirow[b]{2}{*}{$\begin{array}{c}\text { Date } \\
\text { completed }\end{array}$} & \multicolumn{3}{|c|}{ Water level } \\
\hline & & & $\begin{array}{c}\text { Approximate } \\
\text { depth } \\
\text { (meters) }\end{array}$ & $\begin{array}{c}\text { Approximate } \\
\text { altitude } \\
\text { (meters) }^{1}\end{array}$ & $\begin{array}{l}\text { Frequency } \\
\text { monitored }\end{array}$ \\
\hline USW WT-1 & 515 & $5 / 83$ & 471 & 730 & $p$ \\
\hline USW WT-2 & 628 & $7 / 83$ & 570 & 731 & h \\
\hline UE-25 WT \#3 & 348 & $5 / 83$ & 300 & 730 & h \\
\hline UE-25 WT \#4 & 482 & $6 / 83$ & 438 & 731 & p \\
\hline UE-25 WT \#6 & 383 & $6 / 83$ & 280 & 1,034 & p \\
\hline USW WT-7 & 491 & $7 / 83$ & 421 & 776 & p \\
\hline USW WT-10 & 431 & $8 / 83$ & 347 & 776 & p \\
\hline USW WT-11 & 441 & $8 / 83$ & 363 & 731 & $\mathrm{~h}$ \\
\hline UE-25 WT \#12 & 399 & $8 / 83$ & 345 & 729 & $\mathrm{p}$ \\
\hline UE-25 WT \#13 & 354 & $7 / 83$ & 304 & 729 & $\mathrm{~h}$ \\
\hline UE-25 WT \#14 & 399 & $9 / 83$ & 346 & 730 & $\mathrm{p}$ \\
\hline UE-25 WT \#15 & 415 & $11 / 83$ & 354 & 729 & $\mathrm{p}$ \\
\hline UE-25 WT \#16 & 521 & $11 / 83$ & 473 & 738 & $\mathrm{p}$ \\
\hline UE-25 WT \#17 & 443 & $10 / 83$ & 394 & 730 & $\mathrm{p}$ \\
\hline UE-25 WT \#18 & 623 & $5 / 84$ & 605 & 731 & $\mathrm{p}$ \\
\hline UE-25b \#1 & 1,220 & $9 / 81$ & 470 & 731 & $\mathrm{p}$ \\
\hline UE-25p \#1 & 1,805 & $5 / 83$ & 362 & 752 & $\mathrm{~h}$ \\
\hline USW G-2 & 1,831 & $10 / 81$ & 534 & 1,020 & $\mathrm{p}$ \\
\hline USW G-3 & 1,533 & $3 / 82$ & 750 & 731 & $\mathrm{~h}$ \\
\hline USW H-1 & 1,829 & $1 / 81$ & 572 & 731 & $h^{3}$ \\
\hline USW H-3 & 1,219 & $3 / 82$ & 752 & 731 & $\mathrm{~h}$ \\
\hline USW H-4 & 1,219 & $6 / 82$ & 519 & 730 & $\mathrm{~h}$ \\
\hline USW H-5 & 1,219 & $8 / 82$ & 703 & 776 & $\mathrm{~h}$ \\
\hline USW H-6 & 1,220 & $10 / 82$ & 526 & 776 & $\mathrm{~h}$ \\
\hline USW VH-1 & 762 & $2 / 81$ & 184 & 779 & $\mathrm{p}$ \\
\hline$J-11$ & 405 & $7 / 57$ & 317 & 732 & $\mathrm{p}$ \\
\hline $\mathrm{J}-12$ & 2347 & $8 / 68$ & 227 & 728 & $\mathrm{p}$ \\
\hline$J-13$ & 1,063 & $1 / 63$ & 283 & 728 & $\mathrm{p}$ \\
\hline
\end{tabular}

${ }^{1}$ Composite 1993 mean water level of saturated interval, or level of shallowest interval monitored.

${ }^{2}$ Original drilled depth 271 meters in 1957; well deepened to present depth in 1968.

${ }^{3}$ Two of the lower intervals (tubes 1 and 2 ) in well USW H-1 are monitored monthly. 
borehole deviation from vertical. Hourly water-level altitudes are computed based on the calibration, the manual water-level measurement, and the surveyed altitude of the reference point.

This report is a companion and supplement to other reports that present water levels in the Yucca Mountain area (Robison and others, 1988; Gemmell, 1990; O'Brien, 1991; Boucher, 1994; Luckey and others, 1993; Lobmeyer and others, 1995, Tucci and others, 1996; O'Brien and others, 1995).

Robison and others (1988) describe the details of how the manual water-level measurements were made and corrected to compute the water-level altitude.

The water-level data were obtained as part of the Yucca Mountain Project of the U.S. Department of Energy. The Yucca Mountain Project is described by a Site Characterization Plan (U.S. Department of Energy, 1988). The data in this study were collected by the U.S. Geological Survey and its contractors in cooperation with the U.S. Department of Energy under Interagency Agreement DE-AI08-92NV10874.

The data contained in this report were collected by Terry L. Campbell and Rafael Valentin, hydrologic technicians with Foothill Engineering, Inc., under the direction of Darrell A. Baldwin, Foothill Engineering, Inc. The data processing techniques were checked and verified by Michelle $S$. Boucher and Grady M. O’Brien, U.S. Geological Survey.

\section{WELL DESIGNATIONS}

Each well used in the study of the Yucca Mountain area has a unique name or number. Wells on the Nevada Test Site (NTS) use an NTS designation, whereas wells off the NTS use a slightly different designation. Wells on the NTS begin with UE (for Underground Exploratory), followed by the NTS area number (always 25 in this report). This designation-UE-25-commonly is followed by one or more letters signifying the purpose of the well or simply by a sequential letter, followed by a sequence number. Wells off the NTS begin with the letters USW (for Underground, Southern Nevada, Waste). The designation-USW-is followed by one or more letters signifying the purpose of the well followed by a sequence number. The letters signifying purpose that are used in this report are $\mathrm{G}$ (collection of geologic data), $\mathrm{H}$ (collection of hydrologic data), $\mathrm{p}$ (collection of data on rocks of Paleozoic age), $\mathrm{VH}$ (collection of hydrologic and geologic data of volcanic rocks), and WT (collection of water-table data). The only wells not using this designation system and referred to in this report are wells $\mathrm{J}-11, \mathrm{~J}-12$, and $\mathrm{J}-13$, which are water-supply wells.

Nevada State Coordinates are used to identify the location of wells cited in this report. These coordinates are for the central zone of Nevada and are based on a Transverse Mercator projection. The origin of this projection for the central zone of Nevada is latitude $34^{\circ} 45^{\prime} \mathrm{N}$., and the central meridian is at longitude $116^{\circ} 40^{\prime} \mathrm{W}$. The Nevada State Coordinates are in meters north of the baseline and in meters, plus 152,400 east of the central meridian. The Nevada State Coordinate locations for the wells were determined by Holmes \& Narver, Inc., contractor to the U.S. Department of Energy for surveying at the NTS and Yucca Mountain area. Latitude and longitude values of the wells were calculated from the Nevada State Coordinates.

The Site ID number is used for unique identification of the well in the U.S. Geological Survey's data bases. The Site ID is generated by combining the original designations of the latitude and longitude with a two-digit sequence number. The Site ID is for convenience of identification only and should not be used as an actual location number because the original designations of latitude and longitude may be inaccurate. Even if original values of the latitude and longitude are revised later, the Site ID for the well is not changed. If more than one well exists within the 1-second rectangle of latitude and longitude, the two-digit sequence number is used to ensure uniqueness of the Site ID.

Some wells within the water-level network have had packers or piezometers installed so the water level at discrete intervals could be measured. In these instances, before the packers or piezometers were installed, the well was assigned one Site ID (generally with a sequence number of 01), and prior to 1990, each depth interval was assigned its own unique Site ID by incrementing the sequence number. Hence, some wells within the network have several Site ID's. However, since 1990, the water-level data are generally stored in the National Water Information System (NWIS) data base under the Site ID with sequence 
number 01. Exceptions are wells USW H-5 and UE-25p \#1, which use the Site ID with sequence number 02 .

\section{DATA-COLLECTION SYSTEM}

Water-level data are collected at Yucca Mountain by means of manual periodic measurements and by use of pressure transducers that are monitored hourly. Periodic measurements are discussed first, followed by a discussion of the pressure-transducer system. All water-level measurements are subject to various corrections, and these corrections are also discussed.

\section{Periodic Measurements}

Periodic, manual, water-level measurements at wells require visits by trained personnel who perform specific operations and record the results. Operational plans for 1993 called for measurements about once per month at each well. Measurement frequency, however, did vary; water levels in some wells were measured less frequently because of factors such as temporary shortage of trained personnel, breakdown of equipment, or well-site inaccessibility due to road washouts. Few manual measurements were obtained during the third quarter of 1993, because repairs were being made to the measuring equipment at that time. Manual water-level measurements also are made at hourly monitored wells at times of calibration or replacement of defective pressure transducers.

Periodic measurements during 1993 were made using "Chain \#1," "Chain \#2," and "Chain \#3," which are specially constructed reeled steel tapes that are 7.9-mm wide and 792-m long. One measurement each was made at well USW H-3 and well J-11 using the " $2,800-\mathrm{ft}$ reference steel tape," which is a reeled steel tape that is $6.4-\mathrm{mm}$ wide and $853-\mathrm{m}$ long. Detailed descriptions of steel tapes used to measure water levels for this study are given by O'Brien (1991) and are not repeated here.

\section{Corrections and Adjustments to Manual Measurements}

Various factors affect the accuracy of manual water-level measurements and are considered in the process of determining an accurate depth below land surface and the water-level altitude. All measurements in this report have been corrected to obtain the most accurate water-level altitudes. The correction factors applied to steel-tape measurements for each well are summarized in table 2.

Corrections made for steel-tape water-level measurements include mechanical stretch and thermal expansion of the tape. All measurements, except those at wells $\mathrm{J}-11, \mathrm{~J}-12$, and $\mathrm{J}-13$, are corrected for borehole deviation from vertical. Borehole-deviation information is not available for wells $\mathrm{J}-11, \mathrm{~J}-12$, and J-13. All measurements are referenced to sea-level datum.

\section{Mechanical Stretch}

Mechanical stretch is associated with the weight of the suspended steel tape and attached plumb bob (Garber and Koopman, 1968). The calculated adjustment for the steel tapes used during 1993, based on stretch coefficients and an approximate weight of $0.45 \mathrm{~kg}$ for the plumb bob, ranged from -0.044 to $0.017 \mathrm{~m}$ (table 2) for water levels measured in the vicinity of Yucca Mountain.

The correction for mechanical stretch of the tape is given by:

$$
\mathrm{C}=\left(\mathrm{L}^{2} \mathrm{WS}\right) / 2+\mathrm{PLS}-\mathrm{KLS}
$$


Table 2. Corrections applicable to steel tapes used for measuring water levels, 1993, in the vicinity of Yucca Mountain

\begin{tabular}{|c|c|c|c|c|c|c|c|c|c|c|c|c|c|c|}
\hline \multirow{2}{*}{$\begin{array}{l}\text { Well name } \\
\text { (superscript is } \\
\text { tube \# or } \\
\text { interval) }\end{array}$} & \multirow{2}{*}{$\begin{array}{c}\text { Assumed } \\
\text { average } \\
\text { air } \\
\text { temper- } \\
\text { ature, in } \\
\text { well } \\
\text { (degrees } \\
\text { Celsius) }\end{array}$} & \multicolumn{3}{|c|}{$\begin{array}{l}\text { Correction for } 2,800-\text { foot } \\
\text { reference steel tape } \\
\text { (meters) }\end{array}$} & \multicolumn{3}{|c|}{$\begin{array}{l}\text { Correction for Chain \#1 and } \\
\text { Chain \#2 } \\
\text { (meters) }\end{array}$} & \multicolumn{3}{|c|}{$\begin{array}{c}\text { Correction for Chain \#3 } \\
\text { (meters) }\end{array}$} & \multirow{2}{*}{$\begin{array}{l}\text { Correc- } \\
\text { tion for } \\
\text { hole } \\
\text { deviation } \\
\text { from } \\
\text { vertical } \\
\text { (meters) }\end{array}$} & \multicolumn{2}{|c|}{$\begin{array}{c}\begin{array}{c}\text { Measuring } \\
\text { point } \\
\text { (meters) }\end{array} \\
\text { Interval }{ }^{2}\end{array}$} & \multirow{2}{*}{$\begin{array}{c}\text { Reference } \\
\text { point } \\
\text { (meters) }\end{array}$} \\
\hline & & $\begin{array}{l}\text { Mechan- } \\
\text { Ical } \\
\text { stretch }\end{array}$ & $\begin{array}{l}\text { Thermal } \\
\text { expan- } \\
\text { sion }\end{array}$ & Total $^{1}$ & $\begin{array}{l}\text { Mechan- } \\
\text { Ical } \\
\text { stretch }\end{array}$ & $\begin{array}{l}\text { Thermal } \\
\text { expan- } \\
\text { sion }\end{array}$ & Total ${ }^{1}$ & $\begin{array}{l}\text { Mechan- } \\
\text { ical } \\
\text { stretch }\end{array}$ & $\begin{array}{l}\text { Thermal } \\
\text { expan- } \\
\text { sion }\end{array}$ & Total ${ }^{1}$ & & Upper & Lower & \\
\hline USW WT-1 & 25.0 & -0.043 & 0.027 & -0.016 & -0.020 & 0.027 & 0.008 & -0.019 & 0.027 & 0.008 & -0.326 & 0.314 & -- & $1,201.11$ \\
\hline USW WT-2 & 24.4 & -0.038 & 0.029 & -0.009 & -0.012 & 0.029 & 0.017 & -0.010 & 0.029 & 0.019 & -0.533 & 0.311 & .. & $1,301.13$ \\
\hline UE-25 WT \#3 & 26.1 & -0.041 & 0.021 & -0.020 & -0.024 & 0.021 & -0.002 & -0.024 & 0.021 & -0.002 & -0.271 & 0.155 & -- & $1,030.11$ \\
\hline UE-25 WT \#4 & 25.0 & -0.044 & 0.025 & -0.019 & -0.021 & 0.025 & 0.004 & -0.021 & 0.025 & 0.005 & -0.454 & 0.311 & .. & $1,169.21$ \\
\hline UE-25 WT \#6 & 23.3 & -0.040 & 0.011 & -0.029 & -0.023 & 0.011 & -0.012 & -0.023 & 0.011 & -0.013 & -0.204 & 0.463 & -- & $1,314.78$ \\
\hline USW WT-7 & 27.8 & -0.044 & 0.038 & -0.006 & -0.022 & 0.038 & 0.016 & -0.022 & 0.038 & 0.016 & -0.034 & 0.302 & .- & $1,196.88$ \\
\hline USW WT-10 & 29.4 & -0.043 & 0.038 & -0.005 & -0.024 & 0.038 & 0.014 & -0.024 & 0.038 & 0.014 & -0.030 & 0.314 & $\ldots$ & $1,123.40$ \\
\hline USW WT-11 & 28.3 & -0.044 & 0.035 & .0 .009 & -0.024 & 0.035 & 0.011 & -0.023 & 0.035 & 0.012 & -0.116 & 0.311 & -. & $1,094.11$ \\
\hline UE-25 WT \#12 & 27.2 & -0.043 & 0.029 & -0.014 & -0.024 & 0.029 & 0.005 & -0.024 & 0.029 & 0.005 & -0.183 & 0.305 & .. & $1,074.74$ \\
\hline UE-25 WT \#13 & 24.4 & -0.041 & 0.015 & -0.026 & -0.024 & 0.015 & -0.008 & -0.024 & 0.015 & -0.008 & -0.012 & 0.305 & - & $1,032.51$ \\
\hline UE-25 WT \#14 & 24.4 & -0.043 & 0.018 & -0.025 & -0.024 & 0.018 & -0.006 & -0.024 & 0.018 & -0.006 & -0.085 & 0.311 & .. & $1,076.05$ \\
\hline UE-25 WT \#15 & 23.9 & -0.043 & 0.016 & -0.027 & -0.024 & 0.016 & -0.008 & -0.024 & 0.016 & -0.008 & -0.189 & 0.314 & - & $1,082.94$ \\
\hline UE-25 WT \#16 & 26.1 & -0.043 & 0.033 & -0.010 & -0.020 & 0.033 & 0.014 & -0.019 & 0.033 & 0.015 & -0.064 & 0.314 & .. & $1,210.63$ \\
\hline UE-25 WT \#17 & 25.0 & -0.044 & 0.023 & -0.021 & -0.023 & 0.023 & 0.000 & -0.023 & 0.023 & 0.000 & -0.482 & 0.158 & - & $1,124.06$ \\
\hline UE-25 WT \#18 & 25.1 & -0.035 & 0.036 & 0.001 & -0.008 & 0.036 & 0.028 & -0.006 & 0.036 & 0.030 & -0.155 & 0.210 & -- & $1,336.32$ \\
\hline UE- $25 \mathrm{~b} \# 1$ & 25.6 & -0.043 & 0.031 & -0.013 & -0.020 & 0.031 & 0.011 & -0.019 & 0.031 & 0.012 & -0.244 & 0.302 & 0.134 & $1,200.73$ \\
\hline UE-25p \#1 & 25.6 & -0.044 & 0.024 & -0.020 & -0.024 & 0.023 & 0.000 & -0.023 & 0.023 & 0.000 & -0.021 & 0.158 & -- & $1,114.21$ \\
\hline USW G-2 & 22.8 & -0.041 & 0.017 & -0.024 & -0.016 & 0.017 & 0.001 & -0.015 & 0.017 & 0.002 & -0.158 & 0.332 & -. & $1,553.86$ \\
\hline USW G-3 & 23.3 & -0.015 & 0.029 & 0.013 & 0.014 & 0.029 & 0.042 & 0.017 & 0.029 & 0.045 & -0.564 & 0.329 & .- & $1,480.47$ \\
\hline USW H-1 ${ }^{\text {twbe } 1}$ & 25.0 & -0.042 & 0.030 & -0.012 & -0.016 & 0.030 & 0.014 & -0.015 & 0.030 & 0.015 & -0.143 & 0.311 & .. & $1,303.10$ \\
\hline USW $\mathrm{H}-1^{\text {tube } 2}$ & 25.0 & -0.038 & 0.033 & -0.005 & -0.012 & 0.033 & 0.021 & -0.011 & 0.033 & 0.022 & -0.171 & 0.311 & -. & $1,303.10$ \\
\hline USW H-1 ${ }^{\text {tubes } 3,4}$ & 25.0 & -0.038 & 0.033 & -0.005 & -0.012 & 0.033 & 0.022 & -0.010 & 0.033 & 0.028 & -0.174 & 0.311 & -- & $1,303.10$ \\
\hline USW H-3 $3^{\text {upper }}$ & 26.1 & -0.015 & 0.053 & 0.038 & 0.014 & 0.053 & 0.067 & 0.017 & 0.053 & 0.070 & -0.079 & 0.174 & -. & $1,483.47$ \\
\hline USW H-3 $3^{\text {lower }}$ & 26.1 & -0.019 & 0.052 & 0.033 & 0.010 & 0.052 & 0.061 & 0.013 & 0.052 & 0.064 & -0.058 & 0.201 & .. & $1,483.47$ \\
\hline USW H-4 & 24.4 & -0.042 & 0.026 & -0.015 & -0.016 & 0.026 & 0.010 & -0.015 & 0.026 & 0.011 & -0.064 & 0.597 & 0.308 & $1,248.74$ \\
\hline USW H.5 & 23.9 & -0.023 & 0.032 & 0.009 & 0.006 & 0.032 & 0.037 & 0.008 & 0.032 & 0.040 & -0.079 & 0.329 & 0.235 & $1,478.94$ \\
\hline USW H-6 & 25.0 & -0.041 & 0.031 & -0.011 & -0.016 & 0.031 & 0.015 & -0.015 & 0.031 & 0.016 & -0.052 & 0.207 & 0.235 & $1,302.06$ \\
\hline USW VH-1 & 23.9 & -0.031 & 0.008 & -0.022 & -0.019 & 0.008 & -0.011 & -0.019 & 0.008 & -0.011 & -0.049 & 0.631 & .. & 963.23 \\
\hline Well J-11 & 25.0 & -0.042 & 0.018 & -0.023 & -0.024 & 0.018 & -0.005 & -0.024 & 0.018 & -0.005 & unknown & 0.555 & -- & $1,049.45$ \\
\hline Well J-12 & 25.0 & -0.035 & 0.013 & -0.022 & -0.021 & 0.013 & -0.008 & -0.022 & 0.013 & -0.008 & unknown & 0.527 & .- & 954.54 \\
\hline Well J-13 & 25.0 & -0.040 & 0.016 & .0 .023 & -0.023 & 0.016 & -0.007 & -0.023 & 0.016 & -0.007 & unknown & 0.165 & -- & $1,011.47$ \\
\hline
\end{tabular}

${ }^{1}$ Total correction may not equal sum of mechanical stretch and thermal expansion due to rounding.

${ }^{2}$ Wells with only one interval have measuring point listed as upper. 
where

$\mathrm{C}$ is the correction, in meters;

$\mathrm{L}$ is the apparent length of tape, in meters;

$\mathrm{W}$ is the unit weight of the tape, in kilograms per meter;

$\mathrm{S}$ is the stretch coefficient, in meters per (meter kilogram);

$P$ is the weight of the plumb bob, in kilograms; and

$\mathrm{K}$ is reference tension during manufacture, in kilograms.

Values for W were determined at a calibration laboratory at the NTS, and values for S were determined by the U.S. Geological Survey and are estimated to be accurate to 7 percent (R.R. Luckey, U.S. Geological Survey, oral commun., 1993). Values for K are provided by the manufacturer at the time of purchase.

\section{Thermal Expansion}

Thermal expansion of a steel tape or a multiconductor cable occurs because of temperature changes. The calculated correction for thermal expansion for steel tapes is based on manufacturer specifications for thermal-expansion coefficients and on average hole temperatures calculated from temperature profiles in wells at Yucca Mountain (Sass and Lachenbruch, 1982). The correction ranges from +0.008 to $+0.053 \mathrm{~m}$ (table 2).

Correction for thermal expansion of the tape is given by:

$$
E=(D-R) T L,
$$

where

$\mathrm{E}$ is the correction, in meters;

$\mathrm{D}$ is the assumed average air temperature in the well, in degrees Celsius;

$\mathrm{R}$ is the reference temperature during manufacture, in degrees Celsius;

$\mathrm{T}$ is the thermal expansion coefficient, in meters per meter-degree Celsius; and

$\mathrm{L}$ is the apparent length of the tape, in meters.

The tape corrections, which include mechanical stretch and thermal expansion and average air temperature in the well, are given in table 2. Approximate depth to water is analogous to apparent length of the tape, L, in equations 1 and 2. The tape-dependent variables for equations 1 and 2 are defined for each tape in table 3.

Table 3. Mechanical stretch and thermal expansion equation variable values for steel tapes used in the vicinity of Yucca Mountain

\begin{tabular}{lccc}
\hline \multicolumn{1}{c}{ Variable } & $\begin{array}{c}\text { 2,800-ft reference } \\
\text { steel tape }\end{array}$ & $\begin{array}{c}\text { Chain \#1 and } \\
\text { Chain \#2 }\end{array}$ & Chain \#3 \\
\hline Unit weight of the tape, W (kilogram/meter) & $2.08 \times 10^{-2}$ & $2.59 \times 10^{-2}$ & $2.65 \times 10^{-2}$ \\
Stretch coefficient, S [meter/(meter kilogram)] & $2.48 \times 10^{-5}$ & $1.66 \times 10^{-5}$ & $1.69 \times 10^{-5}$ \\
Weight of plumb bob, P (kilogram) & 0.45 & 0.45 & 0.45 \\
Reference tension during manufacture, K (kilogram) & 9.07 & 9.07 & 9.07 \\
Reference temperature during manufacture, R (degree Celsius) & 20 & 20 & 20 \\
Thermal expansion coefficient, T [meter/(meter degree Celsius)] & $1.16 \times 10^{-5}$ & $1.16 \times 10^{-5}$ & $1.16 \times 10^{-5}$ \\
\hline
\end{tabular}




\section{Borehole-Deviation Correction}

In addition to the corrections for mechanical stretch and thermal expansion, corrections must also be made for boreholes that are not vertical (borehole deviation). Gyroscopic surveys were made in all measured wells, except wells $\mathrm{J}-11, \mathrm{~J}-12$, and $\mathrm{J}-13$. The gyroscopic surveys measured borehole deviation from vertical. The difference between measured depth and true vertical depth is the borehole deviation, or borehole correction. Corrections for most wells are $-0.2 \mathrm{~m}$ or less, but they range from -0.01 to $-0.56 \mathrm{~m}$ (table 2). Corrections generally increase with increasing well depth.

\section{Water-Level Altitudes}

Water-level altitudes are calculated by subtracting the corrected depth to water from the altitude of the reference point, which generally is a metal tag on the well casing. The measuring point for the wells, at the top of the access tube, is at some distance above the reference point, and the height of the measuring point is subtracted from the apparent depth to water to calculate the corrected depth to water. Referencepoint and measuring-point values for all wells are listed in table 2 and described in the individual well sections. Water-level altitudes in this report generally are based on a survey of the water-level monitoring network reference points made in late 1984 by the U.S. Geological Survey.

\section{Example Calculation}

An example measurement for well UE-25 WT \#4 for April 28, 1993, is presented to illustrate the calculations made to derive the altitude of the water level. The calculated altitude is the value reported in the section, "Periodic Water-Level Measurements."

Water-level measurements at well UE-25 WT \#4 are taken from the top of a 62-mm inside-diameter steel tube, which is the measuring point (MP). The measurements are corrected to the reference point. Because the altitude of the reference point is accurately known, it is used as a basis for determining the altitude of the water level in the well. The difference in altitude between the MP and the reference point can be measured with a pocket tape; at well UE-25 WT \#4, the MP is $0.311 \mathrm{~m}$ above the reference point (table 2). The water-level measurements, which are recorded to the nearest $0.01 \mathrm{ft}$, are later converted to meters.

At least two measurements of the water level are made and averaged during each visit to the well, and the appropriate corrections are applied after averaging the two water-level measurements. Additional measurements are made only if the two measured depths differ by more than $0.05 \mathrm{ft}$.

\section{Example}

The water-level measurement on April 28, 1993, at UE-25 WT \#4, was made with Chain \#2. The HELD is the indicated footage on the tape when it is held at the MP during a measurement, and CUT is the footage of tape that is wetted during its submersion in the water. The difference between HELD and CUT is the apparent depth to water below the MP. 
The measurements and corrections for UE-25 WT \#4 on April 28, 1993, were:

\begin{tabular}{|c|c|c|c|}
\hline Reading & $\begin{array}{c}\text { Measurement } \\
1\end{array}$ & $\begin{array}{c}\text { Measurement } \\
2\end{array}$ & \\
\hline HELD (ft) & $1,442.00$ & $1,443.00$ & \\
\hline CUT (ft) & -1.14 & -2.15 & \\
\hline Apparent depth to water ( $\mathrm{ft}$ ) & $1,440.86$ & $1,440.85$ & \\
\hline Average of two apparent depths to water (ft) & & & $1,440.855$ \\
\hline Apparent depth to water $(1,440.855 \mathrm{ft} \times 0.3048 \mathrm{~m} / \mathrm{ft})(\mathrm{m})$ & & & 439.172 \\
\hline Measuring point (m) (table 2 ) & & & -0.311 \\
\hline Tape correction (m) (table 2 ) & & & +0.004 \\
\hline Correction for borehole deviation from vertical (m) (table 2) & & & -0.454 \\
\hline Corrected depth below reference point $(\mathrm{m})$ & & & 438.411 \\
\hline \multicolumn{4}{|l|}{ Determination of water-Ievel altitude: } \\
\hline Altitude of reference point (m) (table 2) & & & $1,169.21$ \\
\hline Corrected depth (m) & & & -438.41 \\
\hline Altitude of water level (m) & & & 730.80 \\
\hline
\end{tabular}

\section{Precision and Accuracy}

An analysis of precision and accuracy was conducted for manual water-level measurements, which includes all periodic measurements, obtained during 1988-90 (Boucher, 1994). The precision of the 2,800 - $\mathrm{ft}$ reference steel tape, based on 31 measurements, was $0.026 \mathrm{ft}$. The precision of Chain \#2, based on 341 measurements, was $0.014 \mathrm{ft}$. Ninety-seven percent of all measurements obtained with the steel tapes were precise to within $0.05 \mathrm{ft}$ during 1988-90. The precision of Chain \#1 is believed to be the same or nearly the same as that of Chain \#2 because they have the same physical characteristics and they were identically constructed. The precision of Chain \#3 is not known because of the relatively small set of data obtained in 1993 using that chain.

The overall accuracy of the computed water-level altitude depends on the individual accuracies of its computational components such as: (1) Water-level measurement, (2) borehole correction, (3) height of the measuring point, (4) altitude of the reference point, and (5) the precision of the $2,800-\mathrm{ft}$ reference steel tape. The total accuracy of measurements taken with the steel tapes was estimated to be $0.36 \mathrm{ft}$, neglecting the accuracy of the borehole correction factors (Boucher, 1994). Accuracy of the borehole correction factors is indeterminate because documentation of the borehole-deviation surveys was inadequate to assess their accuracy, and because no borehole-deviation data are available for wells J-11, J-12, and $\mathrm{J}-13$. The unknown accuracy of the borehole corrections poses a problem in the calculation of overall accuracy values.

\section{Hourly Measurements}

Hourly water-level measurements require that equipment be installed in the well to record water levels. Trained personnel install the equipment in the well, periodically calibrate equipment or replace it as necessary, and periodically retrieve the data from the site.

Hourly measurements are of a sufficient frequency that water-level fluctuations are adequately defined to evaluate daily or longer term trends. Hourly measurements are not sufficient, however, to detect short-term, water-level fluctuations, such as those induced by earthquakes (O'Brien, 1992). Hourly measurements were stored and later retrieved from the data loggers at each site. Continuous mea- 
surements were collected at wells USW H-5, USW H-6, and UE-25p \#1 in 1993 to monitor water-level and fluid-pressure response to earthquakes; however, these continuous data are not included in this report.

Pressure transducers and data loggers are used to measure water-level fluctuations. Because of the large depths to water (up to 752 meters), traditional water-level sensing methods, such as float-cablepulley system, water-seeking device, and bubble tube, are not feasible. However, electronic signals from a submerged pressure transducer are relatively easy to transmit through a multi-conductor suspension cable to a recording device accessible to personnel on the surface. Electronic data loggers at the surface are used to control, measure, and store data from the pressure transducers.

\section{Equipment}

The hourly water-level network equipment consists of a pressure transducer, which senses depth of submergence, a wireline cable to transmit voltage between the transducer and the surface, and a data logger to control the system, measure the transducer output, and store the data. An external 12-volt battery provides power to the system, and a solar panel charges the battery.

The wireline cable, consisting of four conductors, appropriate insulation, and two external wire wraps (for strength and stability), is used to transmit voltage between the data logger at the surface and the downhole pressure transducer. The required length of wireline cable to monitor a typical well at Yucca Mountain weighs several tens of kilograms, so power equipment is used to install and calibrate the system.

The water-level monitoring systems are calibrated at least every four months, and the calibration includes a water-level measurement. The water-level measurements are made using either the transducer, a steel tape, or a multiconductor cable unit. Equipment for the water-level measurements, its use, and the necessary corrections and adjustments, are described in detail by Robison and others (1988) and in previous sections of this report. The water-level measurements, after adjustments, result in altitudes of water surface at the time of calibration.

\section{Transducers}

Water-level fluctuations in the hourly network were measured with pressure transducers and pressure transmitters during 1993. Transducers and transmitters are pressure sensors which convert a change in a mechanical quantity (such as pressure) into a change in an electrical quantity (such as resistance). In this report, the term "transducer," refers to either a depth-measurement pressure transducer or pressure transmitter. These sensors are used to measure pressure and are capable of being immersed in water to measure the depth of submersion. Because the transducer remains at a fixed depth in the well, water-level fluctuations are equivalent to changes in the depth of submersion detected by the transducer.

The pressure-sensing components of a transducer consist of a strain gage to convert pressure into electrical resistance and a Wheatstone bridge to allow measurement of the change in resistance. The major difference between pressure transducers and transmitters is the form of the input and output. Pressure transducers use voltage as input and output, whereas pressure transmitters use current as input and output. Pressure transmitters are constructed with the same strain gage and Wheatstone bridge arrangement as a pressure transducer; however, the current input is converted to voltage by an amplifier before it enters the strain gage, and the voltage is converted back to current by a regulator after it passes through the Wheatstone bridge. The required wiring of pressure transducers and transmitters differs because the data loggers are not capable of measuring current. The output signal of a transmitter must be connected to a resistance load, and the drop in voltage across the load is then measured by the data logger. Regardless of which type of pressure sensor is used, the transducer output increases as the depth of submergence increases.

Transducers are made for a range of pressures. Generally, the smaller the pressure range of the transducer, the more accurately pressure changes and water-level fluctuations can be measured. Trans- 
ducer pressure ranges in the hourly water-level network varied from 1 to 5 psi; however, a 5 psi range was most frequently used.

The water-level network historically has used both absolute and gage transducers. An absolute transducer measures pressure relative to a fixed reference pressure, whereas a gage transducer measures pressure relative to atmospheric pressure. A gage transducer has a vent tube from the reference side of the strain gage to above the water surface. Gage transducers are preferable in the water-level network because only water-level fluctuations (and not air-pressure changes) affect the transducer output, and these were used exclusively in the water-level network during 1993.

As a part of the calibration process, a water-level measurement must be obtained by either a manual measurement, using a steel tape, multiconductor cable, or by "tagging" the water level using the transducer. Tagging the water level, which is the more frequently used method of water-level measurement during calibrations, is done by raising or lowering the transducer until it comes in contact with the water surface in the well. The difference in the depth to water from the last manual measurement, indicated by a tape mark on the transducer cable, is then noted in the log book as part of the calibration record. If the transducer is functioning properly, the water level obtained by tagging should be as accurate as a manual measurement; however, if the transducer is not functioning properly, errors in the measured water level (probably less than $0.1 \mathrm{~m}$ ) are possible.

The transducers are calibrated when installed in the well, when removed from the well (if possible), and at least every 4 months while in service in the well. The calibration consists of manually raising or lowering the transducer in increments and noting the change in transducer output. The data logger (described in the next section) is used in the calibration to provide the applied voltage, if necessary, and to measure the output voltage, so the calibration is for the entire transducer/data-logger system and not only for the transducer.

On January 8, 1993, the transducer/data-logger system at well UE-25 WT \#3 was calibrated. The calibration started with the transducer submerged $1.52 \mathrm{~m}$ below the water surface. The following values were obtained:

\begin{tabular}{|cc|}
\hline $\begin{array}{c}\text { Depth of submergence } \\
\text { below water surface } \\
\text { (meters) }\end{array}$ & $\begin{array}{c}\text { Average transducer output } \\
\text { (millivolts) }\end{array}$ \\
\hline 1.52 & 45.04 \\
1.22 & 38.12 \\
1.16 & 37.05 \\
1.10 & 35.61 \\
1.04 & 34.26 \\
0.98 & 32.85 \\
0.91 & 31.43 \\
0.85 & 30.08 \\
0.79 & 28.79 \\
0.73 & 27.30 \\
0.67 & 26.02 \\
0.61 & 24.58 \\
0.30 & 17.69 \\
0.00 & 10.74 \\
\hline
\end{tabular}

The transducer output is the average of three readings taken after the transducer output had stabilized. A regression analysis was performed on the calibration data, excluding any points where the transducer was not submerged. The slope of the regression line for well UE-25 WT \#3 on January 8, 1993, was 0.044 meters per millivolt with a coefficient of determination $\left(\mathrm{r}^{2}\right)$ of 100.0 percent. The slope of the 
regression line, the transducer output at the set point after calibration and before the next calibration, and the water-level measurement at the time of calibration were used to convert transducer output to waterlevel altitude. The set point is the position below the water surface at which the transducer is placed for water-level monitoring.

\section{Data Loggers}

Data-collection platforms (DCP's) that collect, store, and transmit data to a satellite from which the data are relayed to a ground station were used as the primary data-acquisition system during 1993. The Campbell Scientific 21X Micrologger, used in the hourly water-level network as the primary dataacquisition system prior to 1993, is a microprocessor-based system that was used as a supplemental dataacquisition system at selected wells. Details of the $21 \mathrm{X}$ operation and programming are described by Luckey and others (1993) and Lobmeyer and others (1995).

A DCP was first installed at well USW G-3 in December 1989 and at all hourly monitored wells by May 1993. Handar model 570A units were the DCP's used to replace the 21X Micrologger system. The DCP has the same functions as a micrologger, but, in addition to internal storage of data, data are transmitted to a Geostationary Operational Environmental Satellite (GOES). Details of DCP use and operation, and GOES systems are described by Blee and others (1986). Data are collected hourly, stored, and transmitted every 4 hours to a GOES satellite. The data are then relayed to a Direct Readout Ground Station (DRGS) and stored in USGS computers for evaluation and further processing. Data stored internally in the DCP are periodically transferred to computer diskettes. These data are used as backups to the transmitted data, and are used to fill in data gaps due to any malfunctions in the transmission or receiving process.

In addition to transducer output, the data loggers also read information such as battery voltage, excitation voltage, and the panel temperature of the data loggers. These variables are important in evaluation of the reliability of the system. The data loggers store all of the preceding data in memory. Data from the DCP's periodically are transferred to computer diskettes using a portable computer; station ID and time tags are written at the beginning and end of each data file.

\section{Processing and Adjustments}

The data stored in the data loggers and transferred to computers are not water-level data but rather transducer output, in millivolts. The transducer output was converted to water levels, as explained in the following section, "Conversion to Water-Level Altitude." The water-levels are then evaluated by two hydrologists. Anomalous data points, such as those produced during transducer calibrations, by random electronic signals, or due to instrument malfunction, are not retained as water levels.

\section{Conversion to Water-Level Altitude}

In an ideal circumstance, a transducer would be calibrated several times during its operating life, its output would be free of drift, and its characteristics would not change with time. However, this ideal situation rarely occurred, causing the transducer output conversion to be more difficult. As a result, some of the transducer output and resulting converted water levels were not considered reliable.

Converted water levels were evaluated by two hydrologists for data reliability. The hydrologists examined the data at a time scale which clearly showed the hourly and daily fluctuations so that the validity of the data could be determined. The data were compared to barometric-pressure data, earth-tide potential data, and other periods of record for the same site and depth interval. If both hydrologists agreed that the data were valid, the data were retained and included in this report. If one or both hydrologists were not convinced the data were valid, the data were given indeterminate status. The indeterminate status did not necessarily mean the data were invalid; it simply meant that the hydrologists were not con- 
vinced the data were valid. Indeterminate data are not included in this report; however, all raw transducer output data are retained in USGS computer data bases for any potential future evaluation. Transducer data are also transferred to a Yucca Mountain Project archive in Denver, Colo.

The equation for converting transducer output to water-level altitude under ideal conditions is:

$$
\mathrm{W}=\mathrm{W}_{\mathrm{c}}+\left(\mathrm{T}-\mathrm{T}_{\mathrm{c}}\right) \cdot \mathrm{S}_{\mathrm{c}}
$$

where

$\mathrm{W}$ is the water-level altitude, in meters;

$\mathrm{W}_{\mathrm{c}}$ is the water-level altitude at calibration, in meters;

$S_{c}$ is the slope of the regression line, in meters per millivolt;

$\mathrm{T}_{\mathrm{c}}$ is the transducer output at set point following calibration, in millivolts; and

$\mathrm{T}$ is the transducer output, in millivolts.

The following example calculation from UE-25 WT \#3 illustrates how transducer data was converted to water levels. The water-level altitude for the calibration on January 8,1993 , was $729.78 \mathrm{~m}$ (based on a manual measurement). The calibration indicated that a 0.044 -meter change in water level would cause the transducer output to change by approximately 1 millivolt. The transducer output at the post-calibration set point $(0.91 \mathrm{~m}$ below water surface $)$ was 31.10 millivolts. The transducer output at 20:00:00 on January 8, 1993, was 30.71 millivolts. To summarize, equation 3 variables are:

$\mathrm{W}_{\mathrm{c}}=729.78$ meters

$\mathrm{S}_{\mathrm{c}}=0.44 \mathrm{~meters} / \mathrm{millivolt}$

$\mathrm{T}_{\mathrm{c}}=31.10$ millivolts

$\mathrm{T}=30.71$ millivolts

Given these data, the water-level calculation for 20:00:00 on January 8, 1993, would be as follows:

$$
\mathrm{W}=729.78+(30.71-31.10) \cdot 0.044=729.76 \text { meters }
$$

Change in the slope of the regression line, $S_{c}$, and change in the transducer output at set point, $T_{c}$, between consecutive calibrations, are types of drift corrected for in the conversion process. Although the slope of the regression line generally does not change dramatically between calibrations, it usually changes to some degree. The change in slope is assumed to be linear between calibrations. Set-point drift occurs when the expected transducer output (based on manual tags) does not match the actual measured set-point output. Set-point drift is also assumed to be linear over time.

The water-level altitude is assumed to have remained constant from the last transducer output prior to calibration through the first transducer output after calibration. This assumption probably introduces, at most, a few hundredths of a meter error in the calculation of water-level altitude. If more than one calibration was done on a transducer on the same day, the last calibration is used to calculate water-level altitude for the following period, unless the coefficients of determination of the regression lines indicated that another calibration was superior. 


\section{Quality Assurance}

Data in this report will be used to evaluate the suitability of the Yucca Mountain site for a high-level nuclear-waste repository. Confidence in the reliability of water-level data is necessary so the data may be used to assess the expected performance of the repository. A quality-assurance program has been implemented to support the reliability of the data.

\section{Onsite Procedures}

The quality-assurance program requires that water-level measurements be obtained by methods described by formal technical procedures. The technical procedures include calibrations and adjustments done during the measuring operation to ensure that the equipment is operating properly and that expected precision and accuracy are attained. For example, the procedure for measuring water-level changes with a pressure transducer specifies how to install the transducer, how to calibrate, and how to maintain the records of the calibrations.

Data are recorded in logbooks at the well site. Data recorded include time and date of the visit, names of operators making the visit, identification of specific equipment used, calibration data, waterlevel measurement data, and correction factors, if any, applied to the data at the well site. In addition, the entry in the logbooks may include comments concerning factors that may be relevant to the collected data, such as discussion of problems with equipment or weather conditions during the water-level measurement or transducer calibration.

\section{Office Processing and Review}

The original logbooks and records are maintained throughout the calendar year at the onsite operations headquarters on the Nevada Test Site. Photocopies are periodically transmitted to the office of the project chief in Denver, Colo. The records are reviewed for completeness and accuracy and to ensure that proper technical procedures were followed. Any needed adjustments not done during onsite operations, such as tape and borehole-deviation corrections, are made in the Denver office. After data review and any needed adjustments, the logbooks and related records are transferred to a Yucca Mountain Project archive in Denver.

The transducer output is entered into a temporary computer data base and is plotted to facilitate general data review and to discover any instrumentation problems. After this review, the transducer output is converted to water levels. In addition to being published by the U.S. Geological Survey, both the raw transducer output and the water-level altitudes are placed in permanent computer data bases, such as the Unit Values file of the NWIS used by the U.S. Geological Survey. Water-level altitudes obtained from manual measurements are also placed in the computer data base. 


\section{WELL DATA AND WATER LEVELS}

Information and data for individual wells are included in the following sections. Each well is presented in a separate section, which is further subdivided. Each section begins with sources of information about the well, of which most is published information. Borehole-geophysical logs and coremeasurement data for the wells are given by Nelson and others (1991). Previously collected water-level data can be found in Boucher (1994), Gemmell (1990), Lobmeyer and others (1995), Luckey and others (1993), O'Brien (1991, 1992, 1993), Tucci and others (1996), and O'Brien and others (1995). Complete bibliographic citations are in the "References Cited" section. Important information about the well (location and identification, drilling and casing information, access to and description of interval for measuring water levels, and information for calculation of water-level altitude) are summarized in the "Well Specifications" section. Although water-level altitudes are corrected for borehole deviation, other depthrelated values (such as casing or access-tube depths) in the tables are uncorrected. Transducers used to monitor water levels for hourly monitored wells and their calibrations are listed in the "Calibrations and Comments" section. Various statistical information concerning the water levels and hydrographs of water-level altitudes are presented in the "Water-Level Altitudes" section. Hydrographs are uniformly plotted, by year, with a y-axis (water-level) span of $2.5 \mathrm{~m}$. Mean-annual water-level altitude is presented for all measured wells, and mean monthly water-level altitudes are presented for hourly monitored wells.

Mean 1993 water levels generally were lower, overall, than 1992 mean water levels. Mean water levels ranged from $2.13 \mathrm{~m}$ higher (USW H-3, lower interval) to $0.67 \mathrm{~m}$ lower (UE-25 WT \#6) than 1992 mean levels. The water-level rise in well USW H-3, lower interval, is anomalously large because the water level in this interval is still equilibrating in response to well reconfiguration in 1990 . Excluding data for the lower interval of USW H-3, 1993 mean water levels were an average of $0.04 \mathrm{~m}$ lower than 1992 mean levels.

\section{Periodic Water-Level Measurements}

References or information sources, well specifications, periodic water-level measurements, and hydrographs of water-level altitudes are presented in the following sections for individual wells in the periodic water-level network for 1993. Water-level altitudes for 1993 are presented in tables and hydrographs for each well. Mean-annual water-level altitudes for 1993 are compared to the 1992 mean-annual water-level altitudes and are included in the tables. Additional information concerning transducer calibrations and mean-daily water levels are reported for well UE-25b \#1, upper interval, which was monitored hourly from 1/1/93 through 1/11/93. Pumpage information, in terms of total pumpage for 1993, for wells $\mathrm{J}-12$ and $\mathrm{J}-13$ also is reported. 


\section{Well USW WT-1}

Information about the history of well USW WT-1 and about previous data from the well was obtained from various sources. These sources are: Robison (1984, 1986); Robison and others (1988); Holmes \& Narver, Inc. (written commun., 1986); and Fenix \& Scisson, Inc. (1986a, 1987c).

\section{Well specifications}

1. Location and identification:

Latitude and longitude: $36^{\circ} 49^{\prime} 16^{\prime \prime} \mathrm{N}$.; $116^{\circ} 26^{\prime} 56^{\prime \prime} \mathrm{W}$.

Nevada State Central Zone Coordinates (m): N 229,801; E 171,828.

U.S. Geological Survey Site ID: 364916116265601.

2. Drilling and casing information:

Well started: April 28, 1983.

Well completed: May 18, 1983.

Drilling method: Rotary, using rock bits and air, water, and soap-circulating medium; bottom-hole core obtained.

Bit diameter below water level: $222 \mathrm{~mm}$.

Casing: Surface casing only, to a depth of $9.91 \mathrm{~m}$.

Total drilled depth: $515 \mathrm{~m}$.

3. Access to and description of interval for measuring water levels:

62-mm inside-diameter tubing that has a 3.7-m-long well screen on the bottom; tubing and attached screen extend from land surface to a depth of $507.5 \mathrm{~m}$; saturated interval of borehole within tuffaceous beds of Calico Hills to Bullfrog Member of Crater Flat Tuff.

4. Information for calculating water-level altitude:

Reference point: Top of metal tag on well casing, altitude 1,201.11 m (surveyed by

U.S. Geological Survey, 1984).

Measuring point: Top of access tube, $0.314 \mathrm{~m}$.

Depth correction for borehole deviation from vertical: $0.326 \mathrm{~m}$, based on approximate depth to water of $471 \mathrm{~m}$.

\section{Water-level altitudes}

Measured water-level altitudes at well USW WT-1 ranged from 730.22 to $730.35 \mathrm{~m}$. Mean-annual water-level altitude for 1993 was $730.28 \mathrm{~m}$. The mean altitude was $0.10 \mathrm{~m}$ lower than the mean altitude of $730.38 \mathrm{~m}$ for 1992 (O'Brien and others, 1995). Measured water-level altitudes are listed in table 4 and shown in figure 2. 
Table 4. Measured water-level altitudes and yearly mean water-level altitude, 1993, for well USW WT-1

[Method: C1, Chain \# 1; C2, Chain \#2; C3, Chain \#3]

\begin{tabular}{ccc}
\hline Date & $\begin{array}{c}\text { Measured water-level altitude } \\
\text { (meters, above sea level) }\end{array}$ & Method \\
\hline $01 / 20 / 93$ & 730.23 & $\mathrm{C} 1$ \\
$02 / 17 / 93$ & 730.29 & $\mathrm{C} 2$ \\
$03 / 11 / 93$ & 730.29 & $\mathrm{C} 2$ \\
$04 / 23 / 93$ & 730.34 & $\mathrm{C} 2$ \\
$05 / 12 / 93$ & 730.35 & $\mathrm{C} 2$ \\
$06 / 17 / 93$ & 730.27 & $\mathrm{C} 2$ \\
$11 / 19 / 93$ & 730.22 & $\mathrm{C} 3$ \\
$12 / 29 / 93$ & 730.25 & $\mathrm{C} 3$ \\
\hline
\end{tabular}

1993 Mean $=730.28$ meters

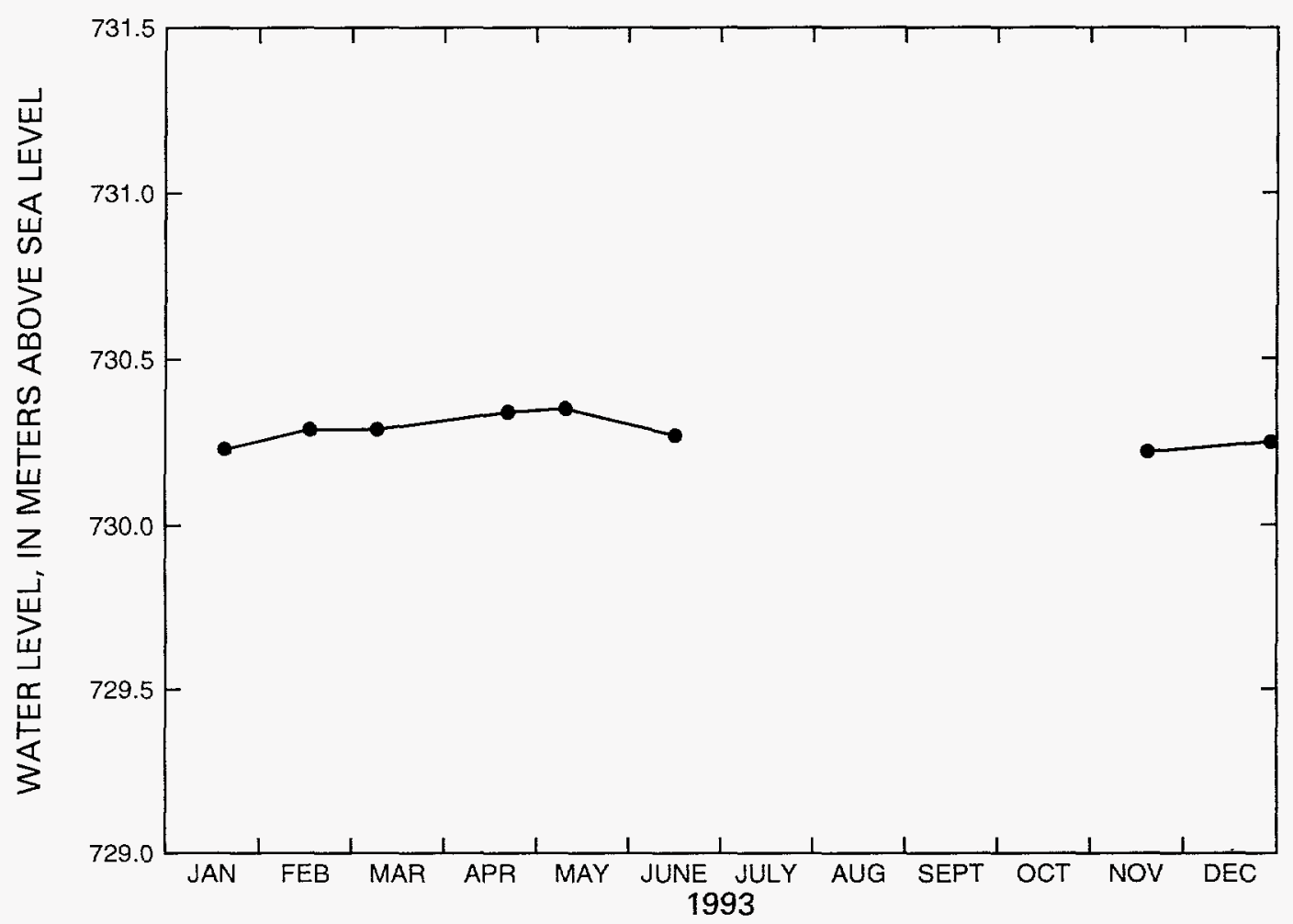

Figure 2. Water-level altitudes, 1993, for well USW WT-1. 


\section{Well UE-25 WT \#4}

Information about the history of well UE-25 WT \#4 and about previous data from the well was obtained from various sources. These sources are: Robison $(1984,1986)$; Robison and others (1988); Holmes \& Narver, Inc. (written commun., 1986); and Fenix \& Scisson, Inc. (1986a, 1987c).

Well specifications

1. Location and identification:

Latitude and longitude: $36^{\circ} 51^{\prime} 40^{\prime \prime} \mathrm{N}$.; $116^{\circ} 26^{\prime} 03^{\prime \prime} \mathrm{W}$.

Nevada State Central Zone Coordinates (m): N 234,242; E 173,139.

U.S. Geological Survey Site ID: 365140116260301.

2. Drilling and casing information:

Well started: May 28, 1983.

Well completed: June 6, 1983.

Drilling method: Rotary, using rock bits and air-foam circulating medium; bottom-hole core obtained.

Bit diameter below water level: $222 \mathrm{~mm}$.

Casing: Surface casing only, to a depth of $14.6 \mathrm{~m}$.

Total drilled depth: $482 \mathrm{~m}$.

3. Access to and description of interval for measuring water levels:

$62-\mathrm{mm}$ inside-diameter tubing that has a $3.7-\mathrm{m}$-long well screen on the bottom; tubing and attached screen extend from land surface to a depth of $477.6 \mathrm{~m}$; saturated interval of borehole within tuffaceous beds of Calico Hills.

4. Information for calculating water-level altitude:

Reference point: Top of metal tag on well casing, altitude $1,169.21 \mathrm{~m}$ (surveyed by U.S. Geological Survey, 1984).

Measuring point: Top of access tube, $0.311 \mathrm{~m}$.

Depth correction for borehole deviation from vertical: $0.454 \mathrm{~m}$, based on approximate depth to water of $438 \mathrm{~m}$.

\section{Water-level altitudes}

Measured water-level altitudes at well UE-25 WT \#4 ranged from 730.75 to $730.89 \mathrm{~m}$. Meanannual water-level altitude for 1993 was $730.82 \mathrm{~m}$. The mean altitude was $0.08 \mathrm{~m}$ lower than the mean altitude of $730.90 \mathrm{~m}$ for 1992 (O'Brien and others, 1995). Measured water-level altitudes are listed in table 5 and shown in figure 3. 
Table 5. Measured water-level altitudes and yearly mean water-level altitude, 1993, for well UE-25 WT \#4

[Method: C2, Chain \#2; C3, Chain \#3]

\begin{tabular}{ccc}
\hline Date & $\begin{array}{c}\text { Measured water-level altitude } \\
\text { (meters, above sea level) }\end{array}$ & Method \\
\hline $02 / 02 / 93$ & 730.83 & $\mathrm{C} 2$ \\
$03 / 03 / 93$ & 730.81 & $\mathrm{C} 2$ \\
$03 / 31 / 93$ & 730.81 & $\mathrm{C} 2$ \\
$04 / 28 / 93$ & 730.80 & $\mathrm{C} 2$ \\
$05 / 17 / 93$ & 730.87 & $\mathrm{C} 2$ \\
$06 / 28 / 93$ & 730.89 & $\mathrm{C} 2$ \\
$11 / 24 / 93$ & 730.77 & $\mathrm{C} 3$ \\
$12 / 29 / 93$ & 730.75 & $\mathrm{C} 3$ \\
\hline
\end{tabular}

1993 Mean $=730.82$ meters.

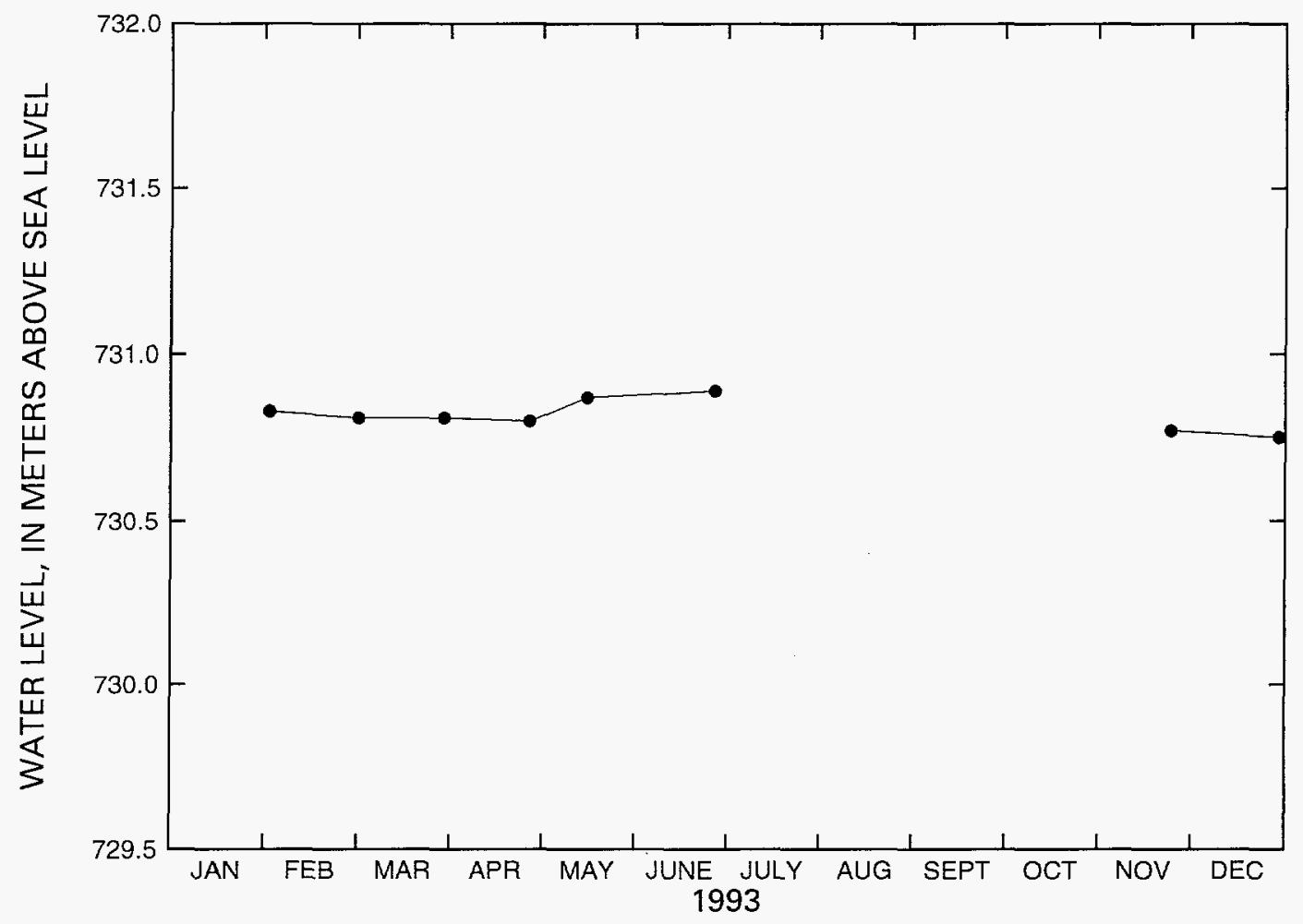

Figure 3. Water-level altitudes, 1993, for well UE-25 WT \#4. 


\section{Well UE-25 WT \#6}

Information about the history of well UE-25 WT \#6 and about previous data from the well was obtained from various sources. These sources are: Robison $(1984,1986)$; Robison and others (1988); and Fenix \& Scisson, Inc. (1986a, 1987c).

\section{Well specifications}

1. Location and identification:

Latitude and longitude: $36^{\circ} 53^{\prime} 40^{\prime \prime} \mathrm{N}$; $116^{\circ} 26^{\prime} 46^{\prime \prime} \mathrm{W}$.

Nevada State Central Zone Coordinates (m): N 237,920; E 172,067.

U.S. Geological Survey Site ID: 365340116264601.

2. Drilling and casing information:

Well started: June 20, 1983.

Well completed: June 29, 1983.

Drilling method: Rotary, using rock bits and air-foam circulating medium; bottom-hole core obtained.

Bit diameter below water level: $171 \mathrm{~mm}$.

Casing: Surface casing only, to a depth of $76.5 \mathrm{~m}$.

Total drilled depth: $383 \mathrm{~m}$.

3. Access to and description of interval for measuring water levels:

62-mm inside-diameter tubing that has a 3.6-m-long well screen on bottom, extending from land surface to a depth of $372 \mathrm{~m}$; saturated interval of borehole within tuffaceous beds of Calico Hills.

4. Information for calculating water-level altitude:

Reference point: Top of metal tag on well casing; altitude 1,314.78 m (surveyed by U.S. Geological Survey, 1984).

Measuring point: Top of access tube, $0.463 \mathrm{~m}$.

Depth correction for borehole deviation from vertical: $0.204 \mathrm{~m}$, based on approximate depth to water of $280 \mathrm{~m}$.

\section{Water-level altitudes}

Measured water-level altitudes for well UE-25 WT \#6 ranged from 1,034.28 to 1,034.40 m in 1993. Mean water-level altitude for 1993 was $1,034.35 \mathrm{~m}$, which was $0.62 \mathrm{~m}$ lower than the 1992 mean of 1,034.97 m (O'Brien and others, 1995). Measured water-level altitudes are listed in table 6 and shown in figure 4. 
Table 6. Measured water-level altitudes and yearly mean water-level altitude, 1993, for well UE-25 WT \#6

[Method: C1, Chain \#1; C2, Chain \#2; C3, Chain \#3]

\begin{tabular}{ccc}
\hline Date & $\begin{array}{c}\text { Water-level altitude } \\
\text { (meters, above sea level) }\end{array}$ & Method \\
\hline $01 / 19 / 93$ & $1,034.33$ & $\mathrm{C} 1$ \\
$02 / 12 / 93$ & $1,034.31$ & $\mathrm{C} 2$ \\
$03 / 08 / 93$ & $1,034.28$ & $\mathrm{C} 2$ \\
$05 / 05 / 93$ & $1,034.35$ & $\mathrm{C} 2$ \\
$05 / 24 / 93$ & $1,034.39$ & $\mathrm{C} 2$ \\
$06 / 21 / 93$ & $1,034.37$ & $\mathrm{C} 2$ \\
$11 / 18 / 93$ & $1,034.40$ & $\mathrm{C} 3$ \\
$12 / 22 / 93$ & $1,034.39$ & $\mathrm{C} 3$ \\
\hline
\end{tabular}

1993 Mean $=1,034.35$ meters.

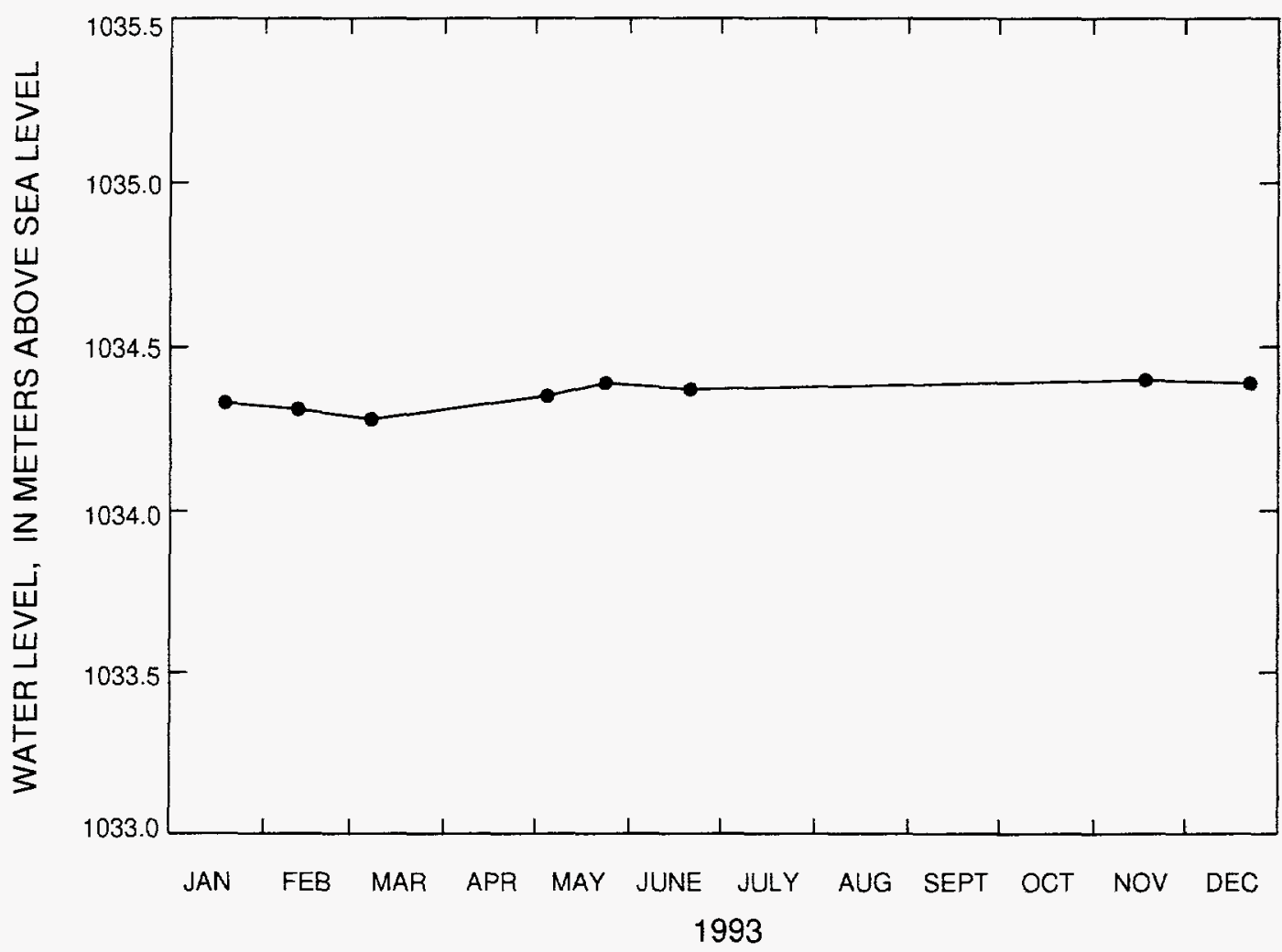

Figure 4. Water-level altitudes, 1993, for well UE-25 WT \#6. 


\section{Well USW WT-7}

Information about the history of well USW WT-7 and about previous data from the well was obtained from various sources. These sources are: Robison $(1984,1986)$; Robison and others (1988); Holmes \& Narver, Inc. (written commun., 1986); and Fenix \& Scisson, Inc. (1986a, 1987c).

Well specifications

1. Location and identification:

Latitude and longitude: $36^{\circ} 49^{\prime} 33^{\prime \prime} \mathrm{N} . ; 116^{\circ} 28^{\prime} 57^{\prime \prime} \mathrm{W}$.

Nevada State Central Zone Coordinates (m): N 230,298; E 168,826.

U.S. Geological Survey Site ID: 364933116285701.

2. Drilling and casing information:

Well started: July 19, 1983.

Well completed: July 26, 1983.

Drilling method: Rotary, using rock bits and air-foam circulating medium; bottom-hole core obtained.

Bit diameter below water level: $222 \mathrm{~mm}$.

Casing: Surface casing only, to a depth of $15.8 \mathrm{~m}$.

Total drilled depth: $491 \mathrm{~m}$.

3. Access to and description of interval for measuring water levels:

62-mm inside-diameter tubing that has a $3.7-\mathrm{m}$-long well screen on the bottom; tubing and attached screen extend from land surface to a depth of $481.3 \mathrm{~m}$; saturated interval of borehole within Topopah Spring Member of Paintbrush Tuff to Prow Pass Member of Crater Flat Tuff.

4. Information for calculating water-level altitude:

Reference point: Top of metal tag on well casing, altitude $1,196.88 \mathrm{~m}$ (surveyed by U.S. Geological Survey, 1984).

Measuring point: Top of access tube, $0.302 \mathrm{~m}$.

Depth correction for borehole deviation from vertical: $0.034 \mathrm{~m}$, based on approximate depth to water of $421 \mathrm{~m}$.

Water-level altitudes

Measured water-level altitudes at well USW WT-7 ranged from 775.81 to $775.91 \mathrm{~m}$. Mean-annual water-level altitude for 1993 was $775.88 \mathrm{~m}$. The mean altitude was $0.01 \mathrm{~m}$ lower than the mean altitude of $775.88 \mathrm{~m}$ for 1992 (O'Brien and others, 1995). Measured water-level altitudes are listed in table 7 and shown in figure 5. 
Table 7. Measured water-level altitudes and yearly mean water-level altitude, 1993, for well USW WT-7

[Method: C2, Chain \#2; C3, Chain \#3]

\begin{tabular}{ccc}
\hline Date & $\begin{array}{c}\text { Measured water-level altitude } \\
\text { (meters, above sea level) }\end{array}$ & Method \\
\hline $04 / 09 / 93$ & 775.91 & $\mathrm{C} 2$ \\
$05 / 28 / 93$ & 775.90 & $\mathrm{C} 2$ \\
$06 / 14 / 93$ & 775.90 & $\mathrm{C} 2$ \\
$07 / 16 / 93$ & 775.90 & $\mathrm{C} 2$ \\
$11 / 09 / 93$ & 775.85 & $\mathrm{C} 3$ \\
$12 / 23 / 93$ & 775.81 & $\mathrm{C} 3$ \\
\hline
\end{tabular}

1993 Mean $=775.88$ meters.

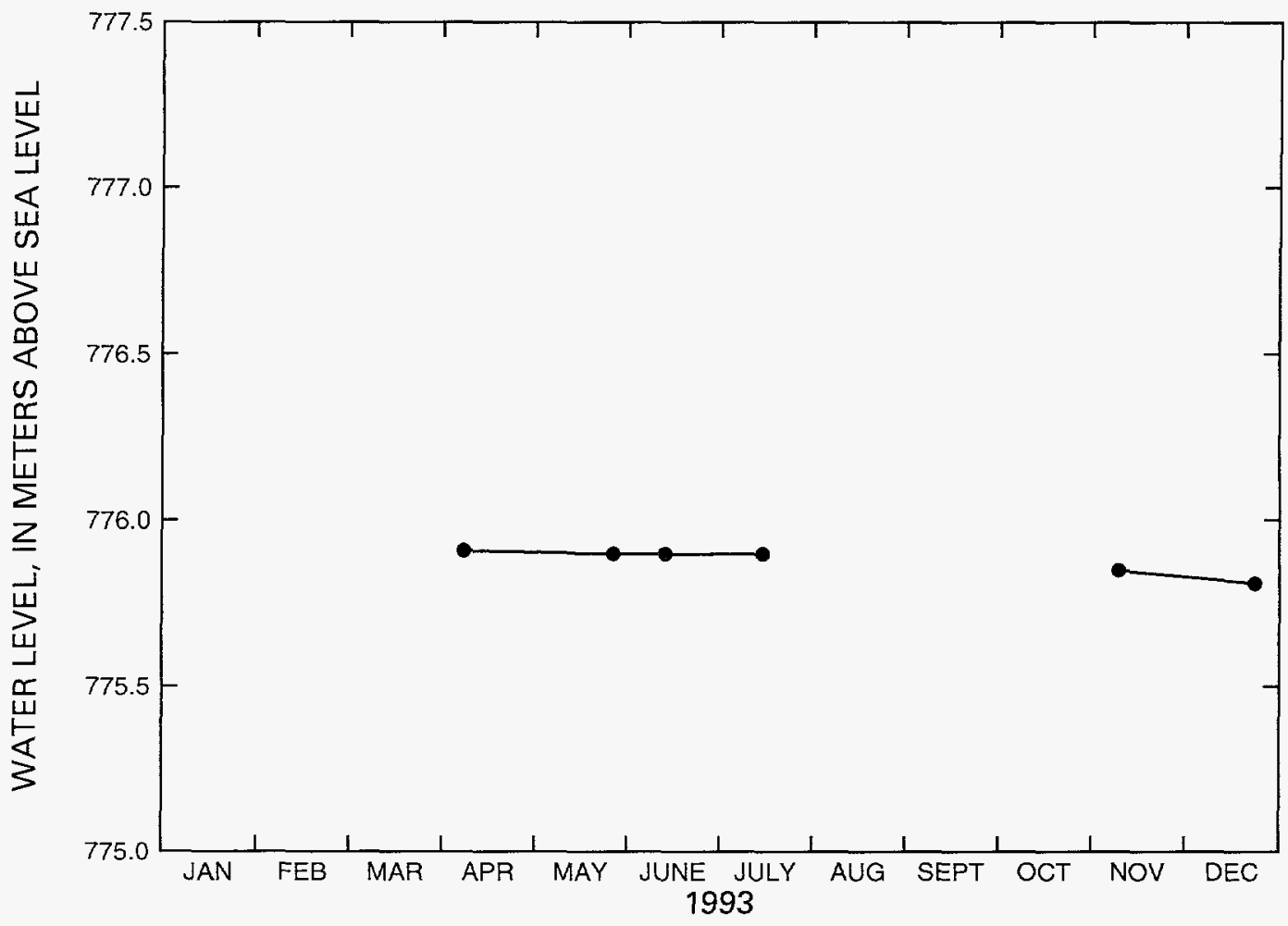

Figure 5. Water-level altitudes, 1993, for well USW WT-7. 


\section{Well USW WT-10}

Information about the history of well USW WT-10 and about previous data from the well was obtained from various sources. These sources are: Robison $(1984,1986)$; Robison and others (1988); Holmes \& Narver, Inc. (written commun., 1986); and Fenix \& Scisson, Inc. (1986a, 1987c).

Well specifications

1. Location and identification:

Latitude and longitude: $36^{\circ} 48^{\prime} 25^{\prime \prime} \mathrm{N}$.; $116^{\circ} 29^{\prime} 05^{\prime \prime} \mathrm{W}$.

Nevada State Central Zone Coordinates (m): N 228,225; E 168,646.

U.S. Geological Survey Site ID: 364825116290501.

2. Drilling and casing information:

Well started: July 26, 1983.

Well completed: August 2, 1983.

Drilling method: Rotary, using rock bits and air-foam circulating medium; bottom-hole core obtained.

Bit diameter below water level: $222 \mathrm{~mm}$.

Casing: Surface casing only, to a depth of $34.7 \mathrm{~m}$.

Total drilled depth: $431 \mathrm{~m}$.

3. Access to and description of interval for measuring water levels:

62-mm inside-diameter tubing that has a 3.7-m-long well screen on the bottom; tubing and attached screen extend from land surface to a depth of $402.6 \mathrm{~m}$; saturated interval of borehole within Topopah Spring Member of Paintbrush Tuff.

4. Information for calculating water-level altitude:

Reference point: Top of metal tag on well casing, altitude 1,123.40 m (surveyed by U.S. Geological Survey, 1984).

Measuring point: Top of access tube, $0.314 \mathrm{~m}$.

Depth correction for borehole deviation from vertical: $0.030 \mathrm{~m}$, based on approximate depth to water of $347 \mathrm{~m}$.

\section{Water-level altitudes}

Measured water-level altitudes at well USW WT-10 ranged from 776.02 to $776.21 \mathrm{~m}$. Mean-annual water-level altitude for 1993 was $776.11 \mathrm{~m}$. The mean altitude was $0.07 \mathrm{~m}$ higher than the mean altitude of $776.04 \mathrm{~m}$ for 1992 (O'Brien and others, 1995). Measured water-level altitudes are listed in table 8 and shown in figure 6. 
Table 8. Measured water-level altitudes and yearly mean water-level altitude, 1993, for well USW WT-10

[Method: C1, Chain \#1; C2, Chain \#2; C3, Chain \#3]

\begin{tabular}{ccc}
\hline Date & $\begin{array}{c}\text { Measured water-level altitude } \\
\text { (meters, above sea level) }\end{array}$ & Method \\
\hline $01 / 25 / 93$ & 776.08 & $\mathrm{C} 1$ \\
$02 / 18 / 93$ & 776.13 & $\mathrm{C} 2$ \\
$03 / 26 / 93$ & 776.16 & $\mathrm{C} 2$ \\
$04 / 22 / 93$ & 776.21 & $\mathrm{C} 2$ \\
$05 / 28 / 93$ & 776.09 & $\mathrm{C} 2$ \\
$06 / 14 / 93$ & 776.12 & $\mathrm{C} 2$ \\
$07 / 16 / 93$ & 776.08 & $\mathrm{C} 2$ \\
$11 / 09 / 93$ & 776.06 & $\mathrm{C} 3$ \\
$12 / 23 / 93$ & 776.02 & $\mathrm{C} 3$ \\
\hline
\end{tabular}

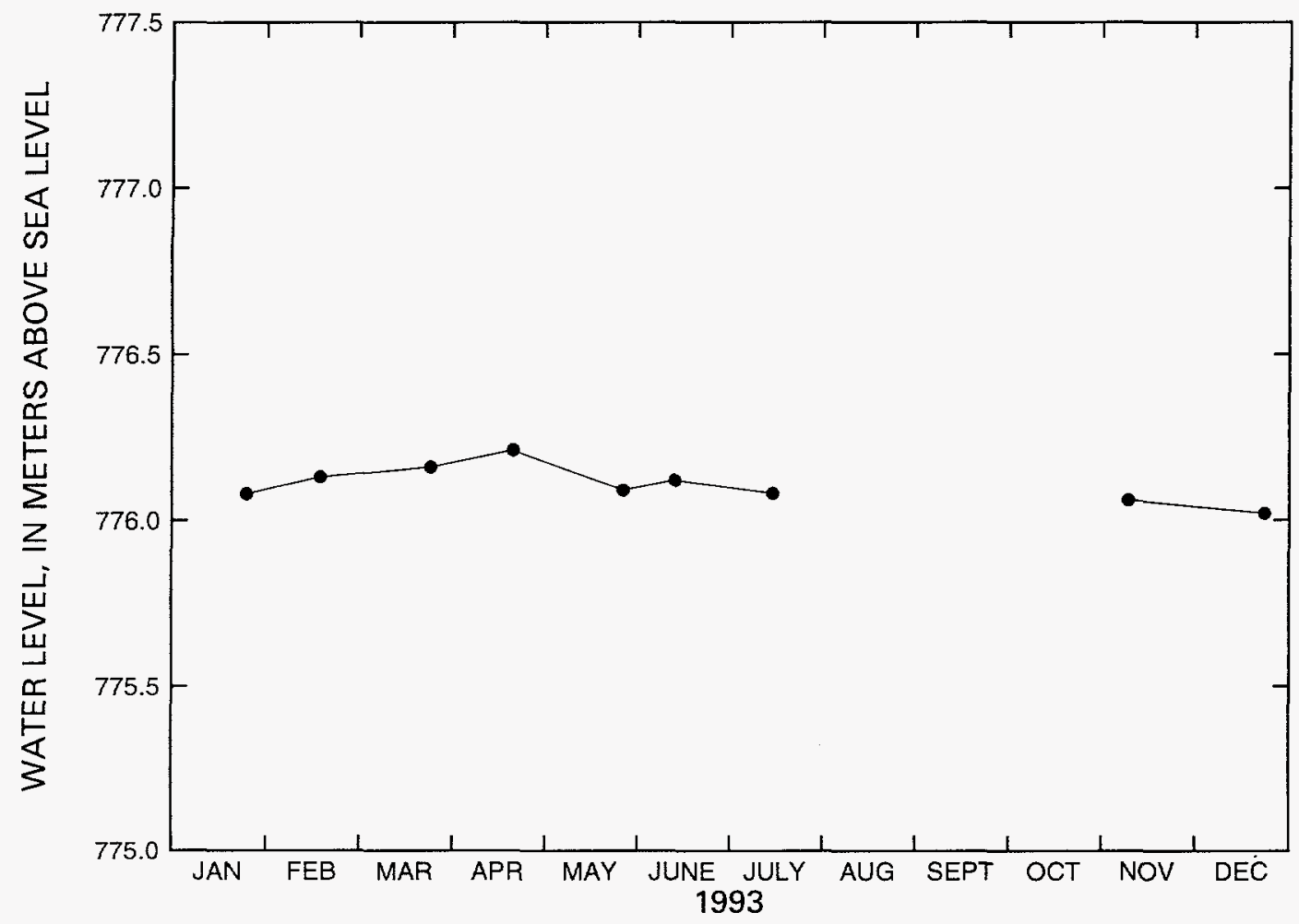

Figure 6. Water-level altitudes, 1993, for well USW WT-10. 


\section{Well UE-25 WT \#12}

Information about the history of well UE-25 WT \#12 and about previous data from the well was obtained from various sources. These sources are: Robison $(1984,1986)$; Robison and others (1988); Holmes \& Narver, Inc. (written commun., 1986); and Fenix \& Scisson, Inc. (1986a, 1987c).

\section{Well specifications}

1. Location and identification:

Latitude and longitude: $36^{\circ} 46^{\prime} 56^{\prime \prime} \mathrm{N} . ; 116^{\circ} 26^{\prime} 16^{\prime \prime} \mathrm{W}$.

Nevada State Central Zone Coordinates (m): N 225,468; E 172,825.

U.S. Geological Survey Site ID: 364656116261601.

2. Drilling and casing information:

Well started: August 11, 1983.

Well completed: August 16, 1983.

Drilling method: Rotary, using rock bits and air-foam circulating medium; bottom-hole core obtained.

Bit diameter below water level: $222 \mathrm{~mm}$.

Casing: Surface casing only, to a depth of $21.3 \mathrm{~m}$.

Total drilled depth: $399 \mathrm{~m}$.

3. Access to and description of interval for measuring water levels:

62-mm inside-diameter tubing that has a 3.7-m-long well screen on the bottom; tubing and attached screen extend from land surface to a depth of $388.9 \mathrm{~m}$; saturated interval of borehole within Topopah Spring Member of Paintbrush Tuff and tuffaceous beds of Calico Hills.

4. Information for calculating water-level altitude:

Reference point: Top of metal tag on well casing, altitude $1,074.74 \mathrm{~m}$ (surveyed by U.S. Geological Survey, 1984).

Measuring point: Top of access tube, $0.305 \mathrm{~m}$.

Depth correction for borehole deviation from vertical: $0.183 \mathrm{~m}$, based on approximate depth to water of $345 \mathrm{~m}$.

\section{Water-level altitudes}

Measured water-level altitudes at well UE-25 WT \#12 ranged from 729.38 to $729.46 \mathrm{~m}$. Meanannual water-level altitude for 1993 was $729.42 \mathrm{~m}$. The mean altitude was $0.08 \mathrm{~m}$ lower than the mean altitude of $729.50 \mathrm{~m}$ for 1992 (O'Brien and others, 1995). Measured water-level altitudes are listed in table 9 and shown in figure 7. 
Table 9. Measured water-level altitudes and yearly mean water-level altitude, 1993, for well UE-25 WT \#12

[Method: C2, Chain \#2; C3, Chain \#3]

\begin{tabular}{ccc}
\hline Date & $\begin{array}{c}\text { Measured water-level altitude } \\
\text { (meters, above sea level) }\end{array}$ & Method \\
\hline $02 / 02 / 93$ & 729.43 & $\mathrm{C} 2$ \\
$03 / 04 / 93$ & 729.38 & $\mathrm{C} 2$ \\
$03 / 30 / 93$ & 729.40 & $\mathrm{C} 2$ \\
$04 / 29 / 93$ & 729.43 & $\mathrm{C} 2$ \\
$06 / 02 / 93$ & 729.46 & $\mathrm{C} 2$ \\
$06 / 29 / 93$ & 729.45 & $\mathrm{C} 2$ \\
$12 / 01 / 93$ & 729.39 & $\mathrm{C} 3$ \\
$12 / 30 / 93$ & 729.43 & $\mathrm{C} 3$ \\
\hline
\end{tabular}

1993 Mean $=729.42$ meters.

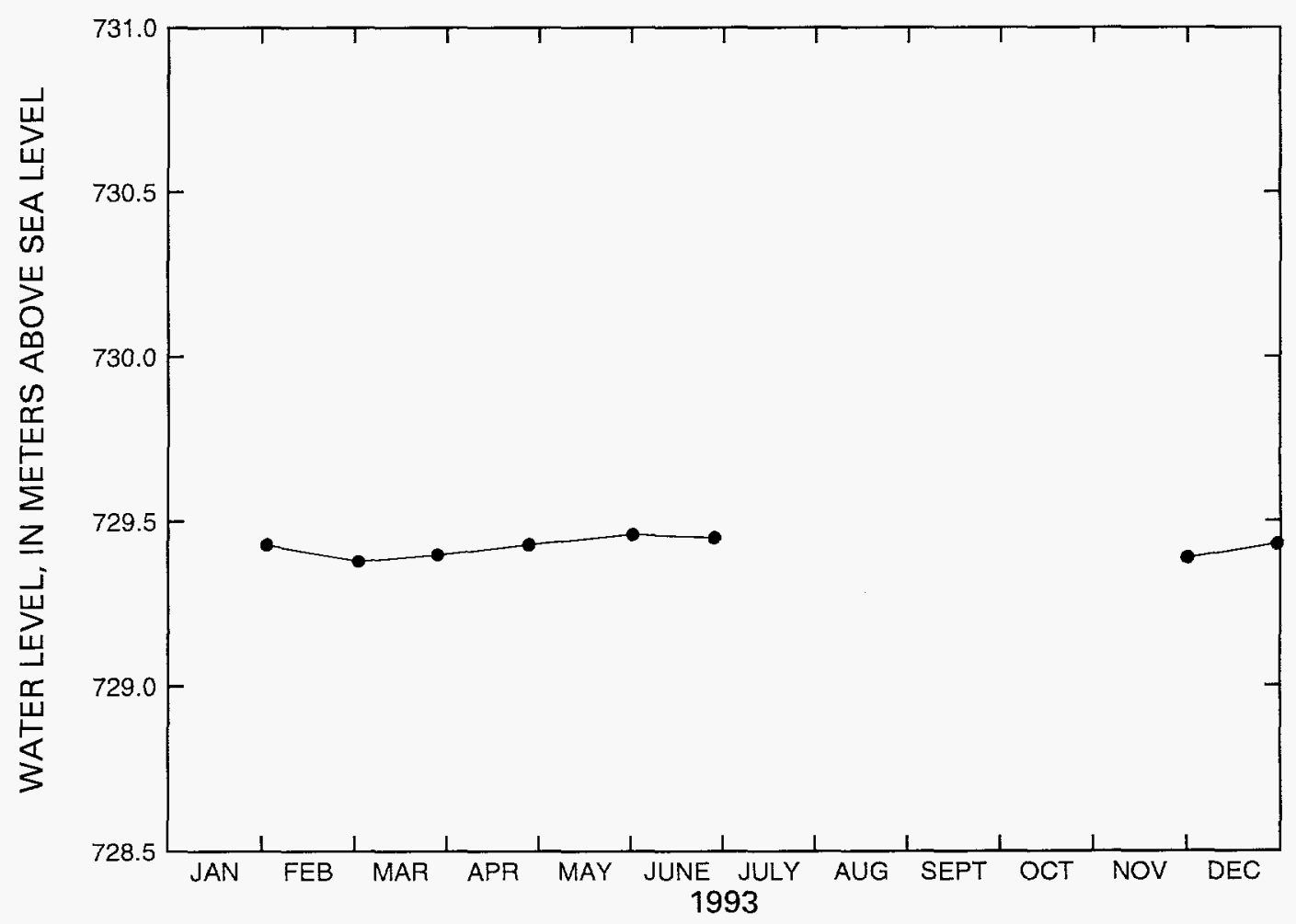

Figure 7. Water-level altitudes, 1993, for well UE-25 WT \#12. 


\section{Well UE-25 WT \#14}

Information about the history of well UE-25 WT \#14 and about previous data from the well was obtained from various sources. These sources are: Robison (1984, 1986); Robison and others (1988); Holmes \& Narver, Inc. (written commun., 1986); and Fenix \& Scisson, Inc. (1986a, 1987c).

\section{Well specifications}

1. Location and identification:

Latitude and longitude: $36^{\circ} 50^{\prime} 32^{\prime \prime} \mathrm{N}$; $116^{\circ} 24^{\prime} 35^{\prime \prime} \mathrm{W}$.

Nevada State Central Zone Coordinates (m): N 232,151; E 175,324.

U.S. Geological Survey Site ID: 365032116243501.

2. Drilling and casing information:

Well started: August 17, 1983.

Well completed: September 30, 1983.

Drilling method: Rotary, using rock bits and air-foam circulating medium; bottom-hole core obtained.

Bit diameter below water level: $222 \mathrm{~mm}$.

Casing: Surface casing only, to a depth of $36.6 \mathrm{~m}$.

Total drilled depth: $399 \mathrm{~m}$.

3. Access to and description of interval for measuring water levels:

62-mm inside-diameter tubing that has a 3.7-m-long well screen on the bottom; tubing and attached screen extend from land surface to a depth of $397.2 \mathrm{~m}$; saturated interval of borehole within Topopah Spring Member of Paintbrush Tuff and tuffaceous beds of Calico Hills.

4. Information for calculating water-level altitude:

Reference point: Top of metal tag on well casing, altitude 1,076.05 m (surveyed by U.S. Geological Survey, 1984).

Measuring point: Top of access tube, $0.311 \mathrm{~m}$.

Depth correction for borehole deviation from vertical: $0.085 \mathrm{~m}$, based on approximate depth to water of $346 \mathrm{~m}$.

\section{Water-level altitudes}

Measured water-level altitudes at well UE-25 WT \#14 ranged from 729.61 to $729.69 \mathrm{~m}$. Meanannual water-level altitude for 1993 was $729.66 \mathrm{~m}$. The mean altitude was $0.06 \mathrm{~m}$ lower than the mean altitude of $729.72 \mathrm{~m}$ for 1992 (O'Brien and others, 1995). Measured water-level altitudes are listed in table 10 and shown in figure 8. 
Table 10. Measured water-level altitudes and yearly mean water-level altitude, 1993, for well UE-25 WT \#14

[Method: C2, Chain \#2; C3, Chain \#3]

\begin{tabular}{ccc}
\hline Date & $\begin{array}{c}\text { Measured water-level altitude } \\
\text { (meters, above sea level) }\end{array}$ & Method \\
\hline $02 / 01 / 93$ & 729.69 & $\mathrm{C} 2$ \\
$03 / 01 / 93$ & 729.64 & $\mathrm{C} 2$ \\
$03 / 29 / 93$ & 729.67 & $\mathrm{C} 2$ \\
$04 / 21 / 93$ & 729.68 & $\mathrm{C} 2$ \\
$06 / 01 / 93$ & 729.68 & $\mathrm{C} 2$ \\
$06 / 21 / 93$ & 729.68 & $\mathrm{C} 2$ \\
$11 / 19 / 93$ & 729.61 & $\mathrm{C} 3$ \\
$12 / 13 / 93$ & 729.64 & $\mathrm{C} 3$ \\
\hline \multicolumn{2}{c}{1993 Mean $=729.66$ meters. }
\end{tabular}

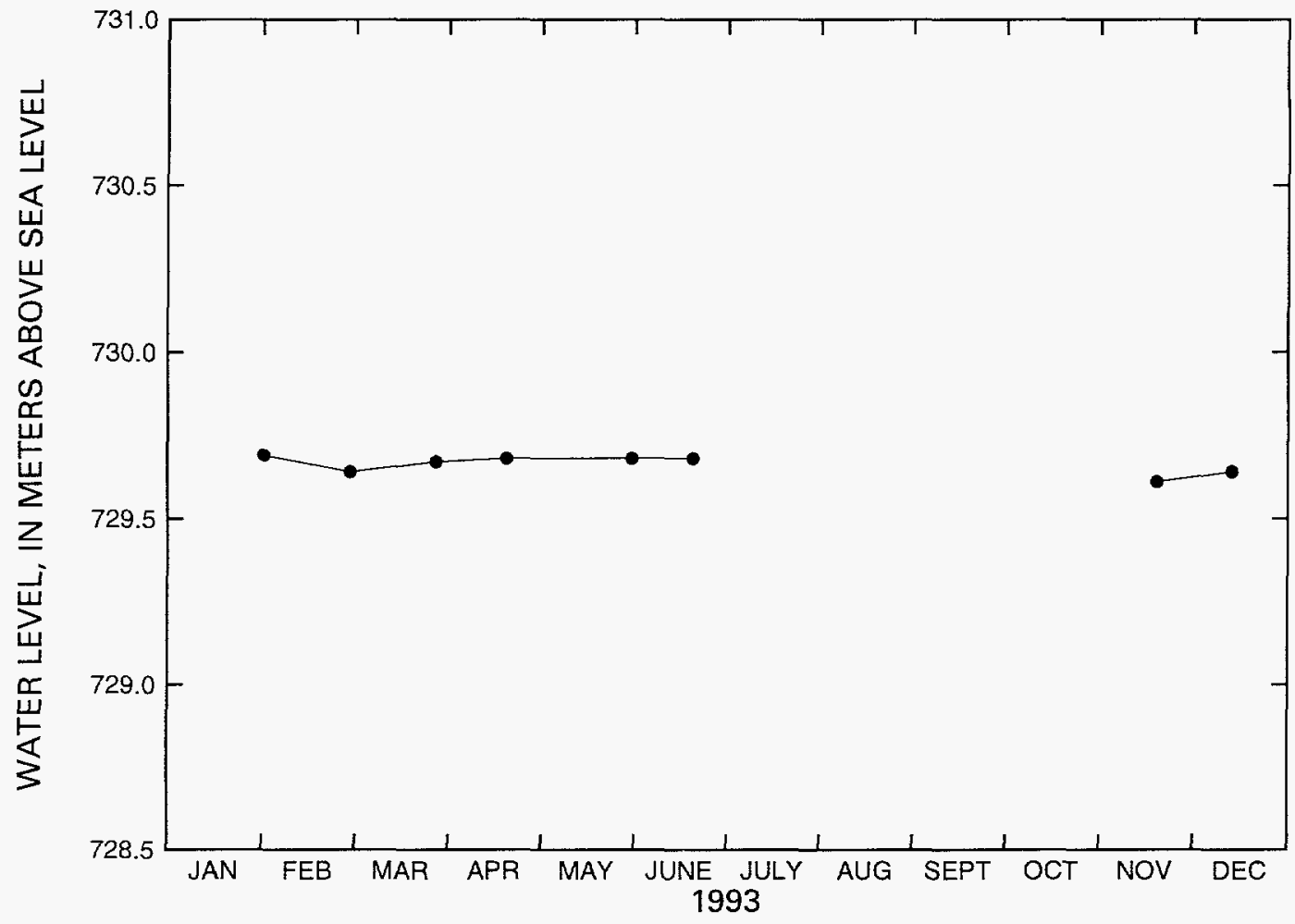

Figure 8. Water-level altitudes, 1993, for well UE-25 WT \#14. 


\section{Well UE-25 WT \#15}

Information about the history of well UE-25 WT \#15 and about previous data from the well was obtained from various sources. These sources are: Robison $(1984,1986)$; Robison and others (1988); Holmes \& Narver, Inc. (written commun., 1986); and Fenix \& Scisson, Inc. (1986a, 1987c).

\section{Well specifications}

1. Location and identification:

Latitude and longitude: $36^{\circ} 51^{\prime} 16^{\prime \prime} \mathrm{N}$; $116^{\circ} 233^{\prime \prime} \mathrm{W}$.

Nevada State Central Zone Coordinates (m): N 233,512; E 176,725.

U.S. Geological Survey Site ID: 365116116233801.

2. Drilling and casing information:

Well started: November 12, 1983.

Well completed: November 22, 1983.

Drilling method: Rotary, using rock bits and air-foam circulating medium; bottom-hole core obtained.

Bit diameter below water level: $222 \mathrm{~mm}$.

Casing: Surface casing only, to a depth of $38.7 \mathrm{~m}$.

Total drilled depth: $415 \mathrm{~m}$.

3. Access to and description of interval for measuring water levels:

62-mm inside-diameter tubing that has a $3.7-\mathrm{m}$-long well screen on the bottom; tubing and attached screen extend from land surface to a depth of $406.9 \mathrm{~m}$; saturated interval of borehole within Topopah Spring Member of Paintbrush Tuff.

4. Information for calculating water-level altitude:

Reference point: Top of metal tag on well casing, altitude $1,082.94 \mathrm{~m}$ (surveyed by

U.S. Geological Survey, 1984).

Measuring point: Top of access tube, $0.314 \mathrm{~m}$.

Depth correction for borehole deviation from vertical: $0.189 \mathrm{~m}$, based on approximate depth to water of $354 \mathrm{~m}$.

\section{Water-level altitudes}

Measured water-level altitudes at well UE-25 WT \#15 ranged from 729.04 to $729.30 \mathrm{~m}$. Meanannual water-level altitude for 1993 was $729.22 \mathrm{~m}$, the same as the mean altitude for 1992 (O'Brien and others, 1995). Measured water-level altitudes are listed in table 11 and shown in figure 9. 
Table 11. Measured water-level altitudes and yearly mean water-level altitude, 1993, for well UE-25 WT \#15

[Method: C2, Chain \#2; C3, Chain \#3]

\begin{tabular}{ccc}
\hline Date & $\begin{array}{c}\text { Measured water-level altitude } \\
\text { (meters, above sea level) }\end{array}$ & Method \\
\hline $02 / 01 / 93$ & 729.25 & $\mathrm{C} 2$ \\
$03 / 01 / 93$ & 729.20 & $\mathrm{C} 2$ \\
$03 / 29 / 93$ & 729.30 & $\mathrm{C} 2$ \\
$05 / 05 / 93$ & 729.30 & $\mathrm{C} 2$ \\
$05 / 24 / 93$ & 729.26 & $\mathrm{C} 2$ \\
$06 / 21 / 93$ & 729.24 & $\mathrm{C} 2$ \\
$11 / 18 / 93$ & 729.18 & $\mathrm{C} 3$ \\
$12 / 22 / 93$ & 729.04 & $\mathrm{C} 3$ \\
\hline
\end{tabular}

1993 Mean $=729.22$ meters.

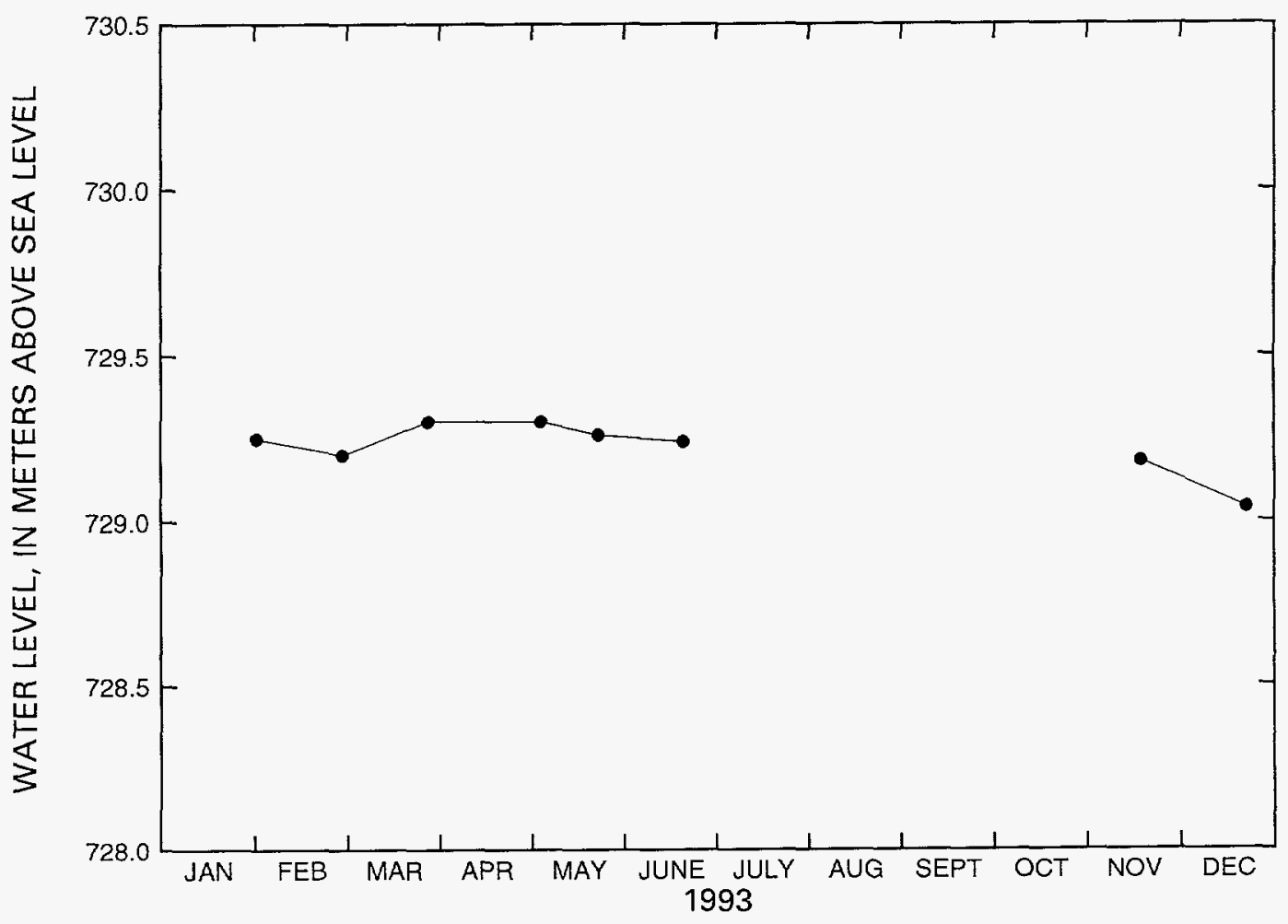

Figure 9. Water-level altitudes, 1993, for well UE-25 WT \#15. 


\section{Well UE-25 WT \#16}

Information about the history of well UE-25 WT \#16 and about previous data from the well was obtained from various sources. These sources are: Robison $(1984,1986)$; Robison and others (1988); and Fenix \& Scisson, Inc. (1986a, 1987c).

\section{Well specifications}

1. Location and identification:

Latitude and longitude: $36^{\circ} 52^{\prime} 39^{\prime \prime} \mathrm{N}$.; $116^{\circ} 25^{\prime} 34^{\prime \prime} \mathrm{W}$.

Nevada State Central Zone Coordinates (m): N 236,043; E 173,856.

U.S. Geological Survey Site ID: 365239116253401.

2. Drilling and casing information:

Well started: November 2, 1983.

Well completed: November 10, 1983.

Drilling method: Rotary, using rock bits and air-foam circulating medium; bottom-hole core obtained.

Bit diameter below water level: $222 \mathrm{~mm}$.

Casing: Surface casing only, to a depth of $31 \mathrm{~m}$.

Total drilled depth: $521 \mathrm{~m}$.

3. Access to and description of interval for measuring water levels:

62-mm inside-diameter tubing that has a 3.6-m-long well screen on bottom, extending from land surface to a depth of $514 \mathrm{~m}$; saturated interval of borehole within tuffaceous beds of Calico Hills.

4. Information for calculating water-level altitude:

Reference point: Top of metal tag on well casing; altitude 1,210.63 m (surveyed by U.S. Geological Survey, 1984).

Measuring point: Top of access tube, $0.314 \mathrm{~m}$.

Depth correction for borehole deviation from vertical: $0.064 \mathrm{~m}$, based on approximate depth to water of $473 \mathrm{~m}$.

\section{Water-level altitudes}

Measured water-level altitudes for well UE-25 WT \#16 ranged from 738.16 to $738.53 \mathrm{~m}$ above sea level in 1993. The mean water-level altitude for 1993 was $738.27 \mathrm{~m}$ above sea level. The mean altitude was $0.15 \mathrm{~m}$ lower than the mean altitude of $738.42 \mathrm{~m}$ for 1992 (O'Brien and others, 1995). Measured water-level altitudes are listed in table 12 and shown in figure 10. 
Table 12. Measured water-level altitudes and yearly mean water-level altitude, 1993, for well UE-25 WT \#16

[Method: C1, Chain \#1; C2, Chain \#2; C3, Chain \#3]

\begin{tabular}{ccc}
\hline Date & $\begin{array}{c}\text { Measured water-level altitude } \\
\text { (meters, above sea level) }\end{array}$ & Method \\
\hline $01 / 19 / 93$ & 738.40 & $\mathrm{C} 1$ \\
$02 / 12 / 93$ & 738.53 & $\mathrm{C} 2$ \\
$03 / 08 / 93$ & 738.21 & $\mathrm{C} 2$ \\
$05 / 05 / 93$ & 738.27 & $\mathrm{C} 2$ \\
$05 / 24 / 93$ & 738.21 & $\mathrm{C} 2$ \\
$06 / 21 / 93$ & 738.16 & $\mathrm{C} 2$ \\
$11 / 18 / 93$ & 738.19 & $\mathrm{C} 3$ \\
$12 / 22 / 93$ & 738.22 & $\mathrm{C} 3$ \\
\hline \multicolumn{2}{c}{ 1993 Mean $=738.27$ meters. } &
\end{tabular}

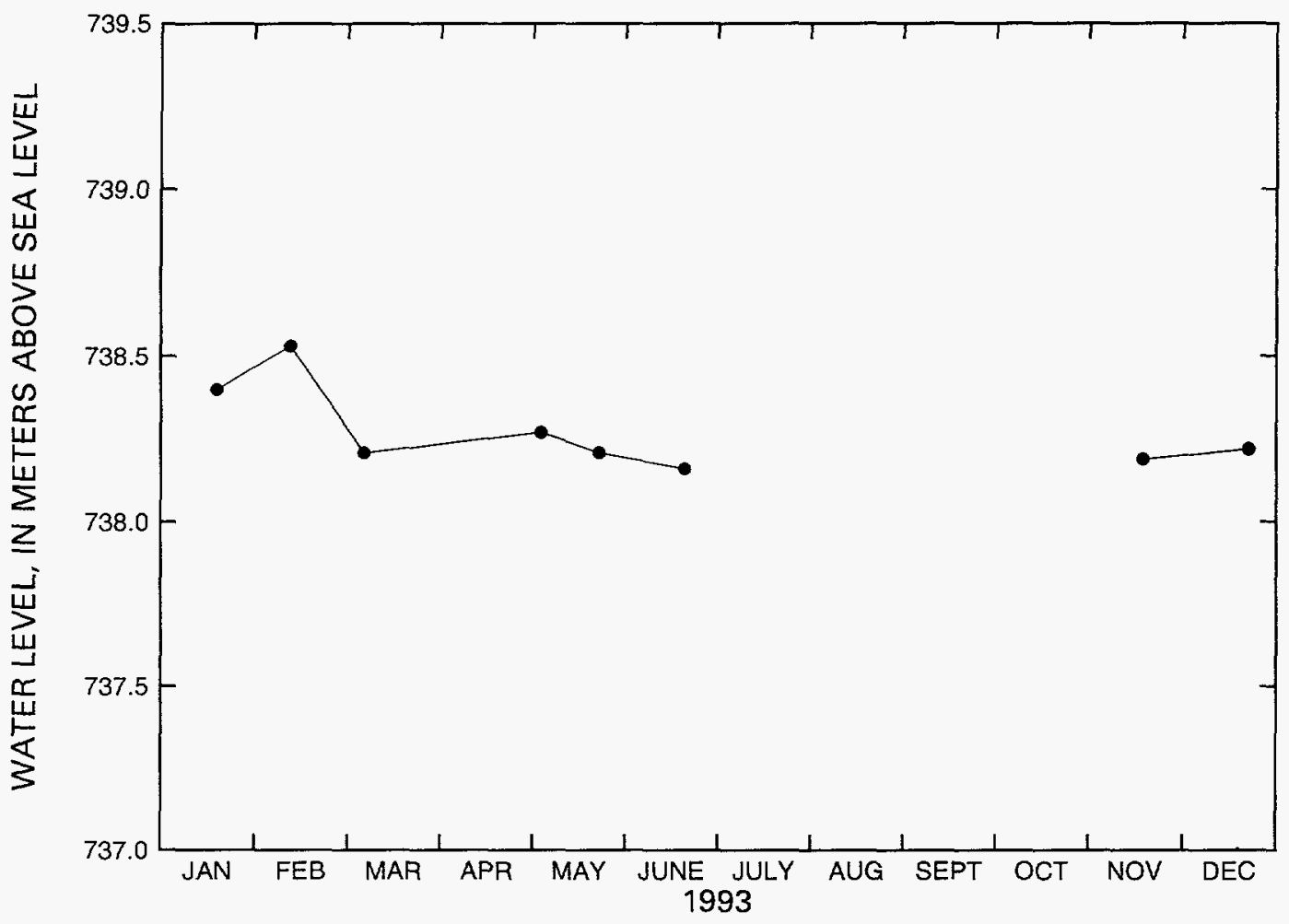

Figure 10. Water-level altitudes, 1993, for well UE-25 WT \#16. 
Well UE-25 WT \#17

Information about the history of well UE-25 WT \#17 and about previous data from the well was obtained from various sources. These sources are: Robison $(1984,1986)$; Robison and others (1988); Holmes \& Narver, Inc. (written commun., 1986); and Fenix \& Scisson, Inc. (1986a, 1987c).

\section{Well specifications}

1. Location and identification:

Latitude and longitude: $36^{\circ} 48^{\prime} 22^{\prime \prime} \mathrm{N}$.; $116^{\circ} 26^{\prime} 26^{\prime \prime} \mathrm{W}$.

Nevada State Central Zone Coordinates (m): N 228,118; E 172,581.

U.S. Geological Survey Site ID: 364822116262601.

2. Drilling and casing information:

Well started: October 20, 1983.

Well completed: October 30, 1983.

Drilling method: Rotary, using rock bits and air-foam circulating medium; attempt to obtain bottom-hole core unsuccessful.

Bit diameter below water level: $222 \mathrm{~mm}$.

Casing: Surface casing only, to a depth of $16.8 \mathrm{~m}$.

Total drilled depth: $443 \mathrm{~m}$.

3. Access to and description of interval for measuring water levels:

62-mm inside-diameter tubing that has a 3.7-m-long well screen on the bottom; tubing and attached screen extend from land surface to a depth of $419.4 \mathrm{~m}$; saturated interval of borehole within Prow Pass Member of Crater Flat Tuff.

4. Information for calculating water-level altitude:

Reference point: Top of metal tag on well casing, altitude 1,124.06 m (surveyed by U.S. Geological Survey, 1984).

Measuring point: Top of access tube, $0.158 \mathrm{~m}$.

Depth correction for borehole deviation from vertical: $0.482 \mathrm{~m}$, based on approximate depth to water of $394 \mathrm{~m}$.

\section{Water-level altitudes}

Measured water-level altitudes at well UE-25 WT \#17 ranged from 729.62 to $729.73 \mathrm{~m}$. Meanannual water-level altitude for 1993 was $729.69 \mathrm{~m}$. The mean altitude was $0.06 \mathrm{~m}$ lower than the mean altitude of $729.75 \mathrm{~m}$ for 1992 (O'Brien and others, 1995). No water-level measurements were obtained in this well during the second half of 1993 because of an obstruction in the access tube. Measured water-level altitudes are listed in table 13 and shown in figure 11. 
Table 13. Measured water-level altitudes and yearly mean water-level altitude, 1993, for well UE-25 WT \#17

[Method: C1, Chain \#1; C2, Chain \#2]

\begin{tabular}{ccc}
\hline Date & $\begin{array}{c}\text { Measured water-level altitude } \\
\text { (meters, above sea level) }\end{array}$ & Method \\
\hline $01 / 20 / 93$ & 729.62 & $\mathrm{C} 1$ \\
$02 / 17 / 93$ & 729.68 & $\mathrm{C} 2$ \\
$03 / 11 / 93$ & 729.68 & $\mathrm{C} 2$ \\
$04 / 23 / 93$ & 729.73 & $\mathrm{C} 2$ \\
$05 / 12 / 93$ & 729.72 & $\mathrm{C} 2$ \\
\hline
\end{tabular}

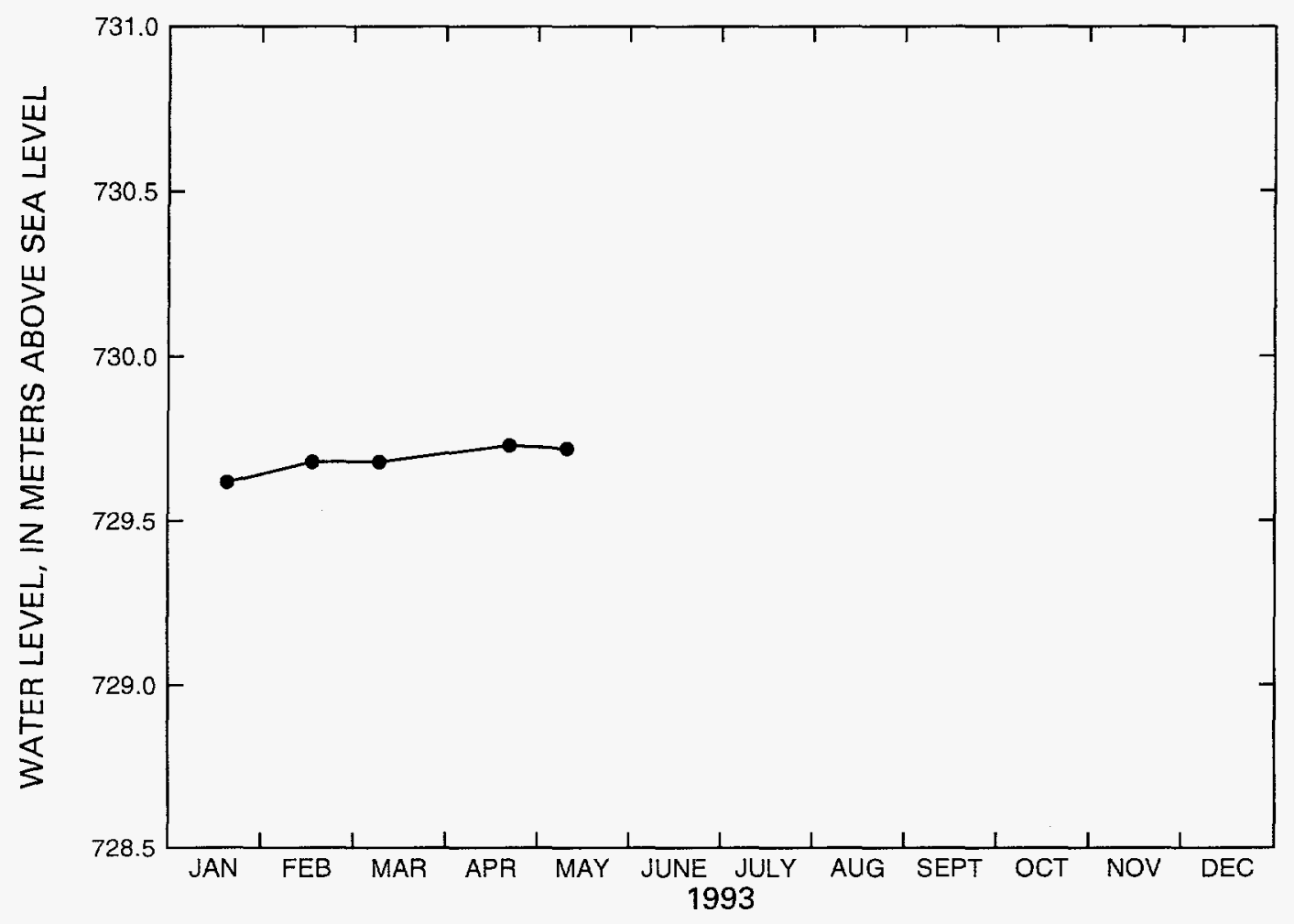

Figure 11. Water-level altitudes, 1993, for well UE-25 WT \#17. 


\section{Well UE-25 WT \#18}

Information about the history of well UE-25 WT \#18 and about previous data from the well was obtained from various sources. These sources are: Fenix \& Scisson, Inc. (1986a); Holmes \& Narver, Inc. (written commun., 1986); and Muller and Kibler (1985).

\section{Well specifications}

1. Location and identification:

Latitude and longitude: $36^{\circ} 52^{\prime} 07^{\prime \prime} \mathrm{N} ; 116^{\circ} 26^{\prime} 42^{\prime \prime} \mathrm{W}$.

Nevada State Central Zone Coordinates (m): N 235,052; E 172,168.

U.S. Geological Survey Site ID: 365207116264201.

2. Drilling and casing information:

Well started: May 9, 1984.

Well completed: May 23, 1984.

Drilling method: Rotary using rock bits and air-foam circulating medium; bottom-hole core obtained.

Bit diameter below water level: $222 \mathrm{~mm}$.

Casing: Surface casing only, to a depth of $27 \mathrm{~m}$.

Total depth drilled: $623 \mathrm{~m}$.

3. Access to and description of interval for measuring water levels:

62-mm inside-diameter tubing that has a 3.7-m-long well screen on the bottom; tubing and attached screen originally extended from land surface to a depth of $597 \mathrm{~m}$, but tubing was extended to a depth of 609 m, December 1990; saturated interval within tuffaceous beds of Calico Hills.

4. Information for calculating water-level altitude:

Reference point: Top of metal tag on well casing, altitude $1336.32 \mathrm{~m}$ (surveyed by U.S. Geological Survey, 1984).

Measuring point: Top of access tube, $0.210 \mathrm{~m}$.

Depth correction for borehole deviation from vertical: $0.155 \mathrm{~m}$, based on approximate depth to water of $607 \mathrm{~m}$.

\section{Water-level altitudes}

Measured water-level altitudes at well UE-25 WT \#18 ranged from 730.75 to $730.81 \mathrm{~m}$. Meanannual water-level altitude for 1993 was $730.77 \mathrm{~m}$. The mean altitude was $0.06 \mathrm{~m}$ lower than the mean altitude of $730.83 \mathrm{~m}$ for 1992 (O'Brien and others, 1995). Measured water-level altitudes are listed in table 14 and shown in figure 12. 
Table 14. Measured water-level altitudes and yearly mean water-level altitude, 1993, for well UE-25 WT \#18

[Method: C2, Chain \#2; C3, Chain \#3]

\begin{tabular}{ccc}
\hline Date & $\begin{array}{c}\text { Measured water-level altitude } \\
\text { (meters, above sea level) }\end{array}$ & Method \\
\hline $02 / 02 / 93$ & 730.75 & $\mathrm{C} 2$ \\
$03 / 03 / 93$ & 730.77 & $\mathrm{C} 2$ \\
$03 / 31 / 93$ & 730.77 & $\mathrm{C} 2$ \\
$04 / 28 / 93$ & 730.76 & $\mathrm{C} 2$ \\
$05 / 17 / 93$ & 730.75 & $\mathrm{C} 2$ \\
$06 / 28 / 93$ & 730.78 & $\mathrm{C} 2$ \\
$11 / 24 / 93$ & 730.80 & $\mathrm{C} 3$ \\
$12 / 29 / 93$ & 730.81 & $\mathrm{C} 3$ \\
\hline \multicolumn{2}{c}{1993 Mean $=730.77$ meters. }
\end{tabular}

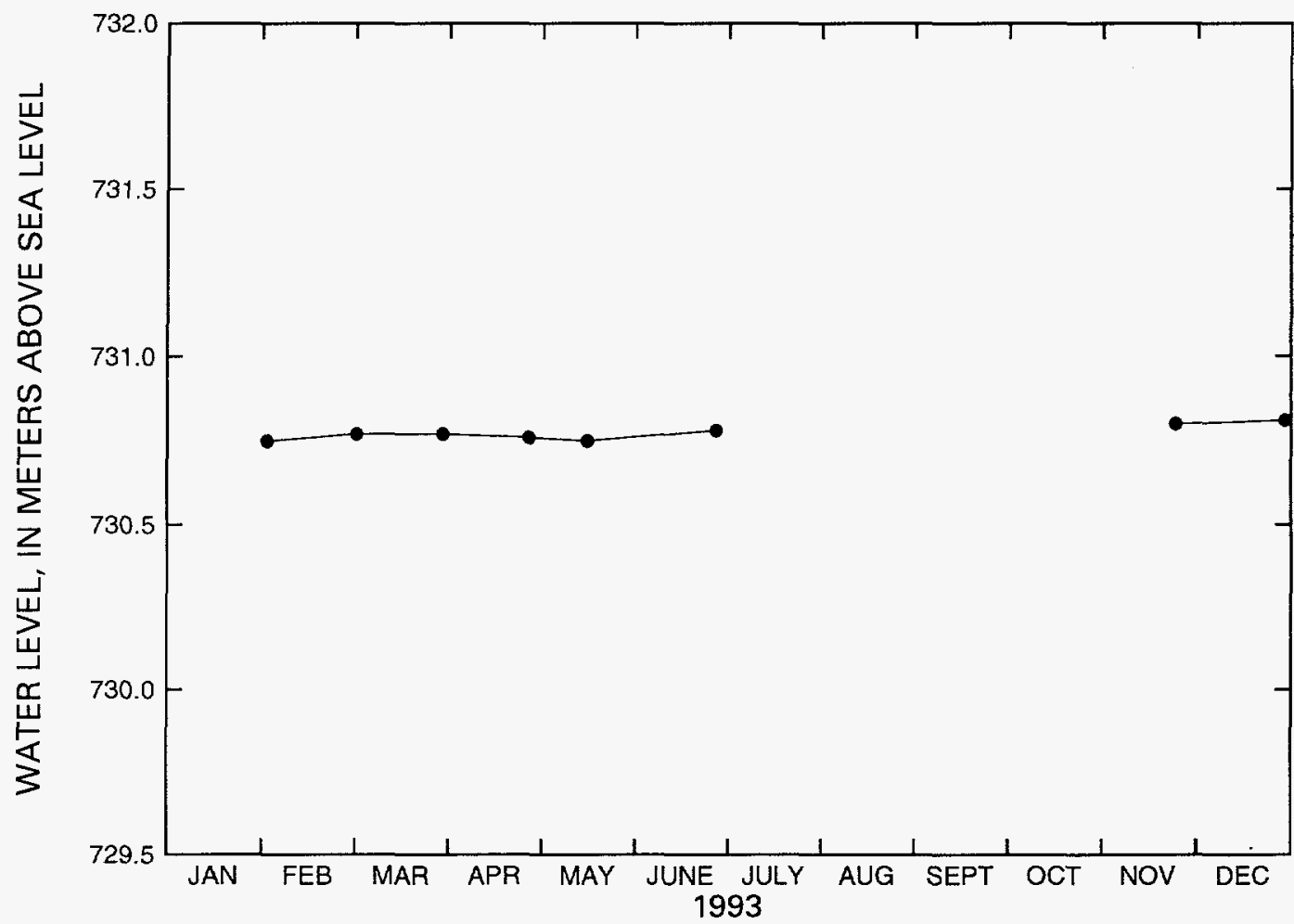

Figure 12. Water-level altitudes, 1993, for well UE-25 WT \#18. 


\section{Well UE-25b \#1}

Information about the history of well UE-25b \#1 and about previous data from the well was obtained from various sources. These sources are: Lobmeyer and others (1983); Lahoud and others (1984); Robison (1984, 1986); Robison and others (1988); and Fenix \& Scisson, Inc. (1986b, 1987c).

\section{Well specifications}

1. Location and identification:

Latitude and longitude: $36^{\circ} 51^{\prime} 08^{\prime \prime} \mathrm{N}$; $116^{\circ} 26^{\prime} 23^{\prime \prime} \mathrm{W}$.

Nevada State Central Zone Coordinates (m): N 233,246; E 172,644.

U.S. Geological Survey Site ID: 365108116262301.

2. Drilling and casing information:

Well started: April 3, 1981.

Well completed: September 22, 1981.

Drilling method: Rotary, using rock bits and air-foam circulating medium; cores obtained in selected intervals.

Bit diameter below water level: $311 \mathrm{~mm}$ to $520 \mathrm{~m} ; 222 \mathrm{~mm}$ to $650 \mathrm{~m} ; 216 \mathrm{~mm}$ from 650 to $1,220 \mathrm{~m}$.

Casing extending below water level: $226-\mathrm{mm}$ inside diameter to $518 \mathrm{~m}$; casing string is tack cemented in and perforated below the water level.

Total drilled depth: $1,220 \mathrm{~m}$.

3. Access to and description of interval for measuring water levels:

\section{Upper interval:}

48-mm inside-diameter tubing, open ended, to depth of about $488 \mathrm{~m}$; upper interval of borehole, from near water table to top of inflatable packer, within tuffaceous beds of Calico Hills, and Prow Pass, Bullfrog, and upper Tram Members of Crater Flat Tuff;

\section{Lower interval:}

62-mm inside-diameter tubing that has an inflatable packer on bottom end, to depth of 1,199 m; lower interval of borehole from below packer to bottom of well, within lower Tram Member of Crater Flat Tuff and Lithic Ridge Tuff.

4. Information for calculating water-level altitude:

Reference point: Top of metal tag on well casing; altitude 1,200.73 m (surveyed by U.S. Geological Survey, 1984).

Measuring point: Top of access tubes, $0.302 \mathrm{~m}$, upper interval; $0.134 \mathrm{~m}$, lower interval.

Depth correction for borehole deviation from vertical: $0.244 \mathrm{~m}$, based on approximate depth to water of $470 \mathrm{~m}$. 


\section{Transducer calibrations and comments}

\section{Upper interval:}

Hourly water-level measurements were obtained in well UE-25b \#1, upper interval, from 1/1/93 to $1 / 12 / 93$, when the monitoring frequency was changed to monthly. One calibration was performed during 1993. In addition, a calibration on 10/21/92 was used to calculate water-level altitudes at the beginning of 1993. Results of the calibrations and measured water-level altitudes obtained during the calibrations are as follows:

\begin{tabular}{ccccc}
\hline $\begin{array}{c}\text { Transducer } \\
\text { serial number }\end{array}$ & $\begin{array}{c}\text { Calibration } \\
\text { date }\end{array}$ & $\begin{array}{c}\text { Slope } \\
(\mathbf{m V} / \mathbf{m})\end{array}$ & $\begin{array}{c}\text { Coefficient of } \\
\text { determination } \\
\left(\mathbf{r}^{\mathbf{2}}\right)\end{array}$ & $\begin{array}{c}\text { Water-level } \\
\text { altitude } \\
(\text { meters })\end{array}$ \\
\hline 274148 & $10 / 21 / 92$ & 11.23 & 1.00 & 730.69 \\
274148 & $01 / 12 / 93$ & 11.19 & 1.00 & 730.61 \\
\hline
\end{tabular}

\section{Lower interval:}

Hourly water-level data collection in this interval was discontinued on 10/21/92, when the monitoring frequency was changed to monthly and transducers were no longer used in the well.

\section{Water-level altitudes}

\section{Upper interval:}

Measured water-level altitudes for well UE-25b \#1, upper interval, ranged from 730.52 to $730.76 \mathrm{~m}$ above sea level in 1993. Mean water-level altitude, calculated using a mean January water level of $730.68 \mathrm{~m}$, for 1993 was $730.61 \mathrm{~m}$ above sea level. The mean altitude was $0.10 \mathrm{~m}$ lower than the mean altitude of $730.71 \mathrm{~m}$ for 1992 (O'Brien and others, 1995). Measured waterlevel altitudes are listed in table 15 and shown in figure 13.

\section{Lower interval:}

Only one water-level measurement was obtained in the lower interval of well UE-25b \#1 in 1993 because of problems with the access tube. The water-level altitude measured on 2/2/93 was $729.92 \mathrm{~m}$ above sea level. 
Table 15. Measured water-level altitudes and yearly mean waterlevel altitude, 1993, for well UE-25b \#1, upper interval

[Method: $\mathrm{C} 1$, Chain \#1; C2, Chain \#2; C3, Chain \#3; T, transducer]

\begin{tabular}{ccc}
\hline Date & $\begin{array}{c}\text { Measured water-level altitude } \\
\text { (meters, above sea level) }\end{array}$ & Method \\
\hline $01 / 01 / 93$ & 730.69 & $\mathrm{~T}$ \\
$01 / 02 / 93$ & 730.70 & $\mathrm{~T}$ \\
$01 / 03 / 93$ & 730.62 & $\mathrm{~T}$ \\
$01 / 04 / 93$ & 730.64 & $\mathrm{~T}$ \\
$01 / 05 / 93$ & 730.66 & $\mathrm{~T}$ \\
$01 / 06 / 93$ & 730.68 & $\mathrm{~T}$ \\
$01 / 07 / 93$ & 730.74 & $\mathrm{~T}$ \\
$01 / 08 / 93$ & 730.76 & $\mathrm{~T}$ \\
$01 / 09 / 93$ & 730.71 & $\mathrm{~T}$ \\
$01 / 10 / 93$ & 730.73 & $\mathrm{~T}$ \\
$01 / 11 / 93$ & 730.63 & $\mathrm{~T}$ \\
$01 / 12 / 93$ & 730.61 & $\mathrm{C} 1$ \\
$02 / 17 / 93$ & 730.60 & $\mathrm{C} 2$ \\
$03 / 24 / 93$ & 730.65 & $\mathrm{C} 2$ \\
$04 / 21 / 93$ & 730.61 & $\mathrm{C} 2$ \\
$05 / 13 / 93$ & 730.61 & $\mathrm{C} 2$ \\
$06 / 28 / 93$ & 730.64 & $\mathrm{C} 2$ \\
$11 / 19 / 93$ & 730.52 & $\mathrm{C} 3$ \\
$12 / 13 / 93$ & 730.60 & $\mathrm{C} 3$ \\
\hline 1993 Mean $=730.61$ meters, calculated using a mean January water \\
level of 730.68 m above sea level. & \\
Values listed for 01/01/93 through 01/11/93 are mean daily water levels. &
\end{tabular}

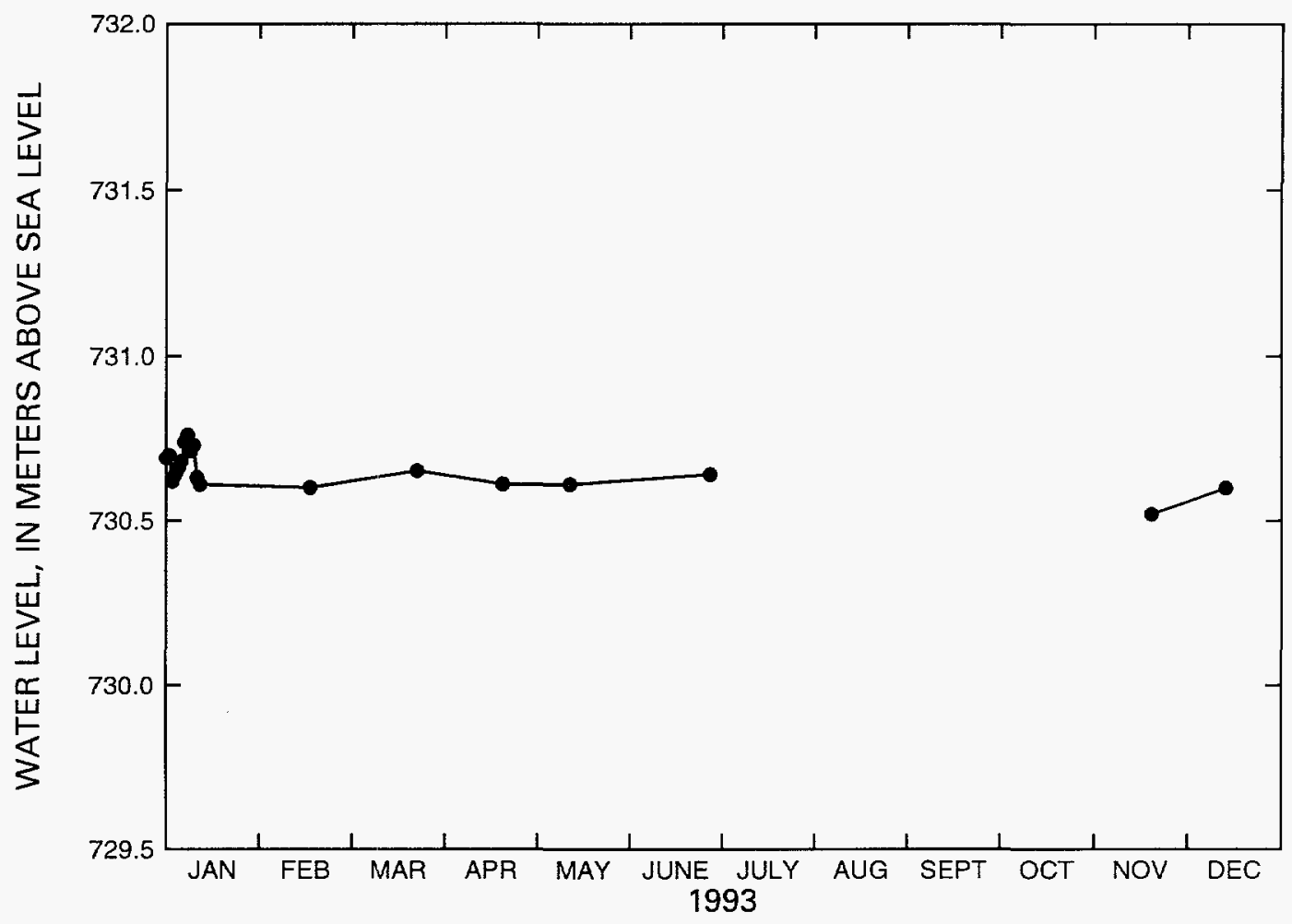

Figure 13. Water-level altitudes, 1993, for well UE-25b \#1, upper interval. 


\section{Well USW VH-1}

Information about the history of well USW VH-1 and about previous data from the well was obtained from various sources. These sources are: Robison (1984, 1986); Robison and others (1988); Holmes \& Narver, Inc. (written commun., 1986); Fenix \& Scisson, Inc. (1986b, 1987c); and Thordarson and Howells (1987).

\section{Well specifications}

1. Location and identification:

Latitude and longitude: $36^{\circ} 47^{\prime} 32^{\prime \prime N}$.; $116^{\circ} 33^{\prime} 07^{\prime \prime} \mathrm{W}$.

Nevada State Central Zone Coordinates (m): N 226,575; E 162,649.

U.S. Geological Survey Site ID: 364732116330701.

2. Drilling and casing information:

Well started: October 28, 1980.

Well completed: February 18, 1981.

Drilling method: Rotary, using rock bits, and air-foam and polymer circulating medium.

Bit diameter below water level: $222 \mathrm{~mm}$ to $278 \mathrm{~m}$; $159 \mathrm{~mm}$ from $278 \mathrm{~m}$ to total depth.

Casing extending below water level: $177-\mathrm{mm}$ inside diameter to $278 \mathrm{~m}$.

Total drilled depth: $762 \mathrm{~m}$.

3. Access to and description of interval for measuring water levels:

48-mm inside-diameter tubing, open ended from land surface to $205.4 \mathrm{~m}$; saturated interval of well within Tiva Canyon and Topopah Spring Members of the Paintbrush Tuff, and Prow Pass, and Bullfrog Members of Crater Flat Tuff. A pump was installed in the well on July 8, 1982, at a depth of $212.8 \mathrm{~m}$.

4. Information for calculating water-level altitude:

Reference point: Top of metal tag on well casing, altitude $963.23 \mathrm{~m}$ (surveyed by Holmes \& Narver, Inc., March 3, 1986).

Measuring point: Top of access tube, $0.631 \mathrm{~m}$.

Depth correction for borehole deviation from vertical: $0.049 \mathrm{~m}$, based on approximate depth to water of $184 \mathrm{~m}$.

Water-level altitudes

Measured water-level altitudes at well USW VH-1 ranged from 779.39 to $779.51 \mathrm{~m}$. Mean-annual water-level altitude for 1993 was $779.46 \mathrm{~m}$. The mean altitude was $0.03 \mathrm{~m}$ higher than the mean altitude of $779.43 \mathrm{~m}$ for 1992 (O'Brien and others, 1995). Measured water-level altitudes for well USW VH-1 are listed in table 16 and shown in figure 14. 
Table 16. Measured water-level altitudes and yearly mean water-level altitude, 1993, for well USW VH-1

[Method: C1, Chain \#1; C2, Chain \#2; C3, Chain \#3]

\begin{tabular}{ccc}
\hline Date & $\begin{array}{c}\text { Measured water-level altitude } \\
\text { (meters, above sea level) }\end{array}$ & Method \\
\hline $01 / 13 / 93$ & 779.48 & $\mathrm{C} 1$ \\
$02 / 04 / 93$ & 779.48 & $\mathrm{C} 2$ \\
$02 / 18 / 93$ & 779.48 & $\mathrm{C} 2$ \\
$03 / 02 / 93$ & 779.46 & $\mathrm{C} 2$ \\
$03 / 26 / 93$ & 779.49 & $\mathrm{C} 2$ \\
$04 / 09 / 93$ & 779.48 & $\mathrm{C} 2$ \\
$04 / 22 / 93$ & 779.51 & $\mathrm{C} 2$ \\
$05 / 11 / 93$ & 779.48 & $\mathrm{C} 2$ \\
$05 / 28 / 93$ & 779.46 & $\mathrm{C} 2$ \\
$06 / 14 / 93$ & 779.47 & $\mathrm{C} 2$ \\
$06 / 25 / 93$ & 779.46 & $\mathrm{C} 2$ \\
$07 / 16 / 93$ & 779.45 & $\mathrm{C} 2$ \\
$11 / 09 / 93$ & 779.41 & $\mathrm{C} 3$ \\
$12 / 23 / 93$ & 779.39 & $\mathrm{C} 3$ \\
\hline
\end{tabular}

1993 Mean $=779.46$ meters.

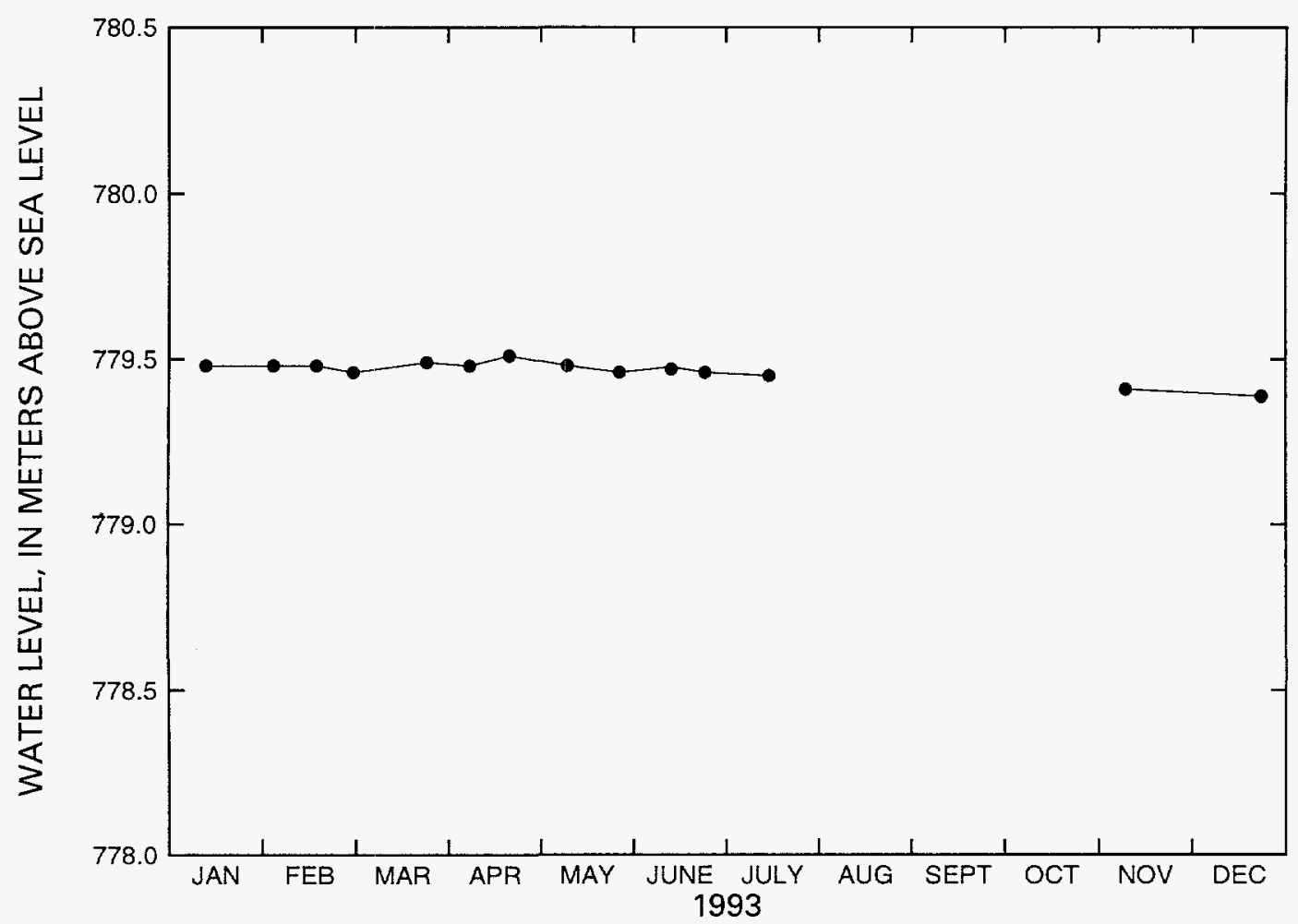

Figure 14. Water-level altitudes, 1993, for well USW VH-1. 


\section{Well USW G-2}

Information about the history of well USW G-2 and about previous data from the well was obtained from various sources. These sources are: Maldonado and Koether (1983); Robison $(1984,1986)$;

Robison and others (1988); Holmes \& Narver, Inc. (written commun., 1986); Fenix \& Scisson, Inc. (1987b, 1987c); and Nelson and Schimschal (1993).

\section{Well specifications}

1. Location and identification:

Latitude and longitude: $36^{\circ} 53^{\prime} 22^{\prime \prime} \mathrm{N} . ; 116^{\circ} 27^{\prime} 35^{\prime \prime} \mathrm{W}$.

Nevada State Central Zone Coordinates (m): N 778,825; E 560,503.

U.S. Geological Survey Site ID: 365322116273501.

2. Drilling and casing information:

Well started: March 25, 1981.

Well completed: October 24, 1981.

Drilling method: Rotary, using rock bits, with polymer mud to $88 \mathrm{~m}$; cored from $88 \mathrm{~m}$ to total depth.

Bit diameter below water level: $222 \mathrm{~mm}$ to $814 \mathrm{~m} ; 159 \mathrm{~mm}$ from 814 to $947 \mathrm{~m} ; 156 \mathrm{~mm}$ from 947 to $1,439 \mathrm{~m} ; 76 \mathrm{~mm}$ from $1,439 \mathrm{~m}$ to total depth.

Casing extending below water level: None (surface casing, $320 \mathrm{~mm}$ inside diameter, 0-85 m and 276-mm inside diameter, 0-242 $\mathrm{m}$ ).

Total drilled depth: $1,831 \mathrm{~m}$.

3. Access to and description of interval for measuring water levels:

Saturated interval of borehole within Topopah Springs Member of the Paintbrush Tuff, tuffaceous beds of the Calico Hills, Prow Pass, Bullfrog, and Tram Members of the Crater Flat Tuff, Lithic Ridge Tuff, and older flows and tuffs. Bridge plug at a depth of $806 \mathrm{~m}$.

4. Information for calculating water-level altitude:

Reference point: Top of metal tag on well casing, altitude $1,553.86 \mathrm{~m}$ (surveyed by U.S. Geological Survey, 1984).

Measuring point: Top of casing, $0.332 \mathrm{~m}$ after $2 / 3 / 93,0.033 \mathrm{~m}$ prior to $2 / 3 / 93$.

Depth correction for borehole deviation from vertical: $0.158 \mathrm{~m}$, based on approximate depth to water of $524 \mathrm{~m}$.

\section{Water-level altitudes}

Measured water-level altitudes at well USW G-2 ranged from 1,020.11 to 1,020.38 m. Meanannual water-level altitude for 1993 was $1,020.28 \mathrm{~m}$. The mean altitude was $8.56 \mathrm{~m}$ lower than the altitude of $1,028.84 \mathrm{~m}$ for $9 / 17 / 82$ reported by Robison and others (1988, p. 86), which was the most recent published water level for this well prior to this report. Measured water-level altitudes for well USW G-2 are listed in table 17 and shown in figure 15 . 
Table 17. Measured water-level altitudes and yearly mean water-level altitude, 1993, for well USW G-2

[Method: C2, Chain \#2; C3, Chain \#3]

\begin{tabular}{ccc}
\hline Date & $\begin{array}{c}\text { Measured water-level altitude } \\
\text { (meters, above sea level) }\end{array}$ & Method \\
\hline $02 / 03 / 93$ & $1,020.38$ & $\mathrm{C} 2$ \\
$03 / 10 / 93$ & $1,020.36$ & $\mathrm{C} 2$ \\
$04 / 19 / 93$ & $1,020.34$ & $\mathrm{C} 2$ \\
$05 / 07 / 93$ & $1,020.37$ & $\mathrm{C} 2$ \\
$06 / 28 / 93$ & $1,020.37$ & $\mathrm{C} 2$ \\
$10 / 20 / 93$ & $1,020.17$ & $\mathrm{C} 2$ \\
$11 / 24 / 93$ & $1,020.18$ & $\mathrm{C} 3$ \\
$12 / 29 / 93$ & $1,020.11$ & $\mathrm{C} 3$ \\
\hline
\end{tabular}

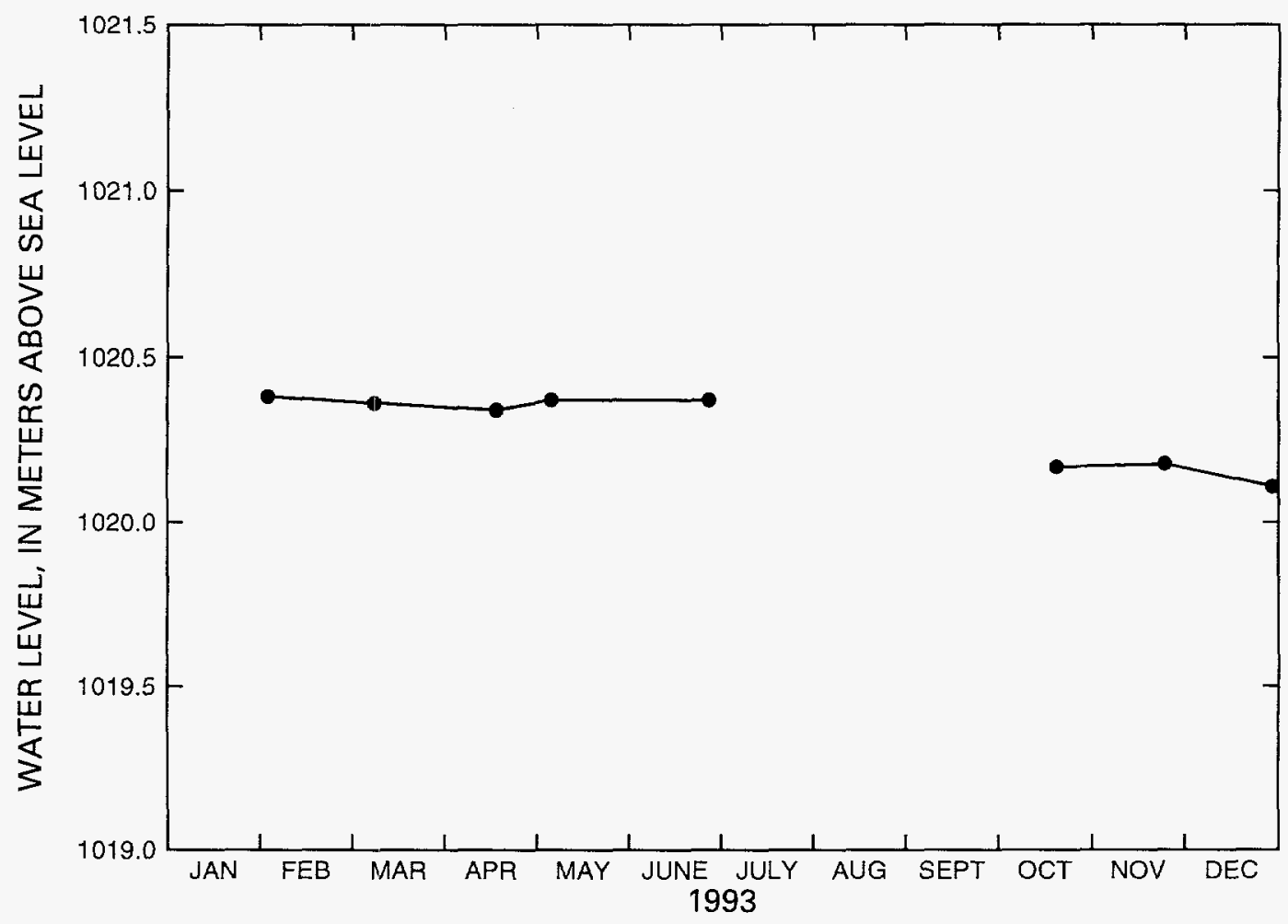

Figure 15. Water-level altitudes, 1993, for well USW G-2. 
Well J-11

Information about the history of well USW J-11 and about previous data from the well was obtained from R.A. Young, 1972, and Fenix \& Scisson, Inc., 1987.

\section{Well specifications}

1. Location and identification:

Latitude and longitude: $36^{\circ} 47^{\prime} 06^{\prime \prime} \mathrm{N}$.; $116^{\circ} 17^{\prime} 06^{\prime \prime} \mathrm{W}$.

Nevada State Central Zone Coordinates (m): N 740,968; E 611,764.

U.S. Geological Survey Site ID: 364706116170601.

2. Drilling and casing information:

Well started: June 4, 1957.

Well completed: July 19, 1957.

Drilling method: Cable-tool.

Bit diameter below water level: $400 \mathrm{~mm}$.

Casing extending below water level: $308-\mathrm{mm}$ inside-diameter casing extends from land surface to $404.5 \mathrm{~m}$.

Total drilled depth: $405 \mathrm{~m}$.

3. Access to and description of interval for measuring water levels:

$308-\mathrm{mm}$ inside-diameter casing; the casing is perforated from 328.3 to $334.4 \mathrm{~m}$ and from 379.2 to $396.2 \mathrm{~m}$. The well produces water from the basalt of Kiwi Mesa and from the welded-tuff aquifer, located within the Topopah Spring Member of the Paintbrush Tuff.

4. Information for calculating water-level altitude:

Reference point: Chiseled " $X$ " in concrete pad near well; altitude 1,049.45 m (surveyed by U.S. Geological Survey, 1993).

Measuring point: Top of casing, even with top of concrete block, $0.555 \mathrm{~m}$.

Depth correction for borehole deviation from vertical is not available.

Water-level altitudes

Measured water-level altitudes at well J-11 ranged from 732.10 to $732.33 \mathrm{~m}$. Mean water-level altitude for 1993 was $732.21 \mathrm{~m}$. The mean altitude $0.01 \mathrm{~m}$ higher than the mean altitude of $732.20 \mathrm{~m}$ for 1992 (O'Brien and others, 1995). Measured water-level altitudes are listed in table 18 and shown in figure 16. 
Table 18. Measured water-level altitudes and yearly mean water-level altitude, 1993, for well J-11

[Method: C2, Chain \#2; C3, Chain \#3; R, 2,800-foot reference tape]

\begin{tabular}{ccc}
\hline Date & $\begin{array}{c}\text { Measured water-level altitude } \\
\text { (meters, above sea level) }\end{array}$ & Method \\
\hline $02 / 02 / 93$ & 732.20 & $\mathrm{C} 2$ \\
$03 / 04 / 93$ & 732.10 & $\mathrm{C} 2$ \\
$03 / 30 / 93$ & 732.19 & $\mathrm{C} 2$ \\
$05 / 05 / 93$ & 732.23 & $\mathrm{C} 2$ \\
$06 / 01 / 93$ & 732.23 & $\mathrm{C} 2$ \\
$06 / 21 / 93$ & 732.22 & $\mathrm{C} 2$ \\
$12 / 01 / 93$ & 732.15 & $\mathrm{C} 3$ \\
$12 / 15 / 93$ & 732.33 & $\mathrm{R}$ \\
\hline
\end{tabular}

1993 Mean $=732.21$ meters.

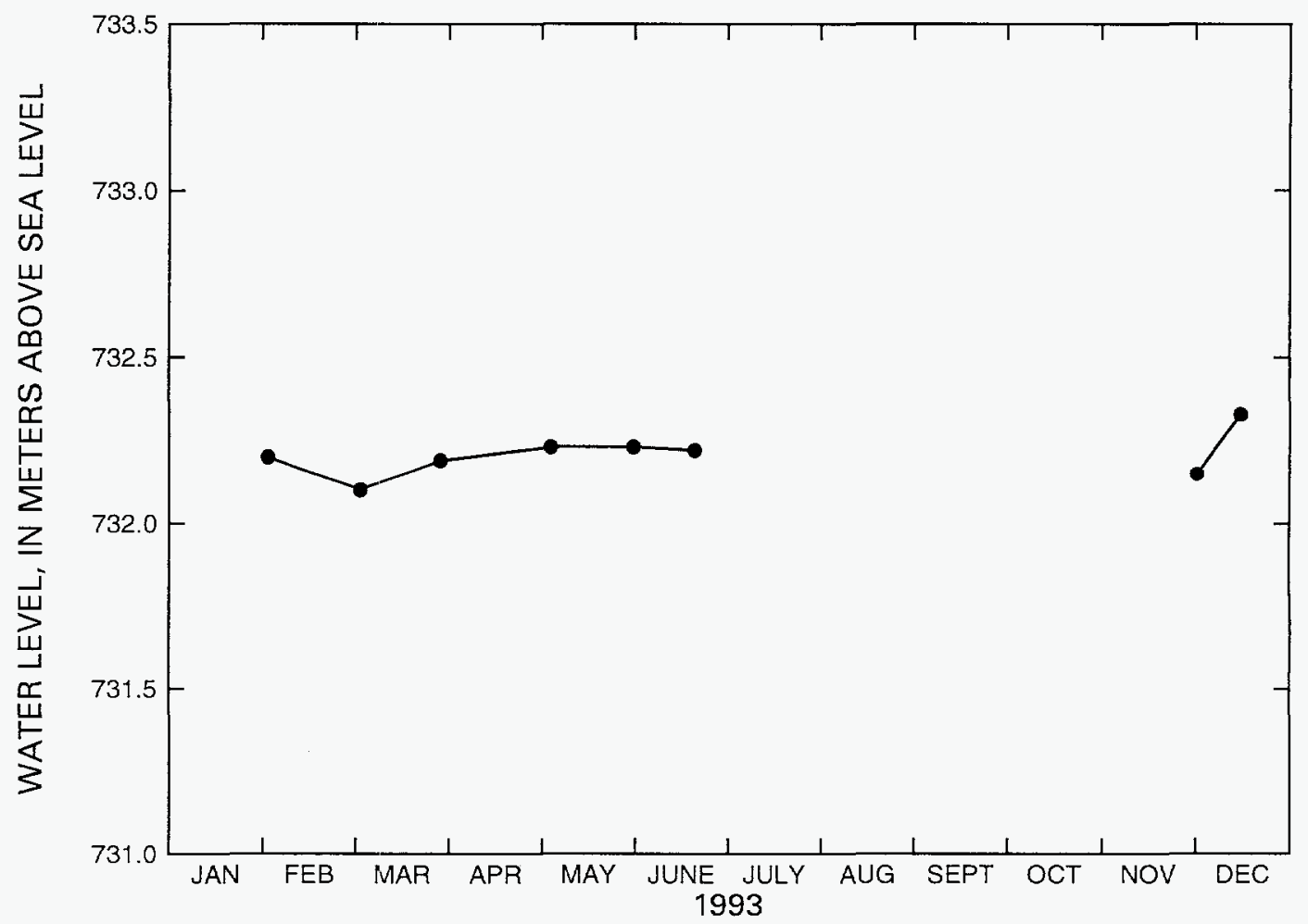

Figure 16. Water-level altitudes, 1993, for well J-11. 


\section{Well J-12}

Information about the history of well USW J-12 and about previous data from the well was obtained from R.A. Young, 1972, and Fenix \& Scisson, Inc., 1987.

\section{Well specifications}

1. Location and identification:

Latitude and longitude: $36^{\circ} 45^{\prime} 54^{\prime \prime} \mathrm{N}$.; $116^{\circ} 23^{\prime} 24^{\prime \prime} \mathrm{W}$.

Nevada State Central Zone Coordinates (m): N 733,508; E 581,012.

U.S. Geological Survey Site ID: 364554116232401.

2. Drilling and casing information:

Well started: August 4, 1957.

Well completed: October 9, 1957; well was deepened in August 1968.

Drilling method: Cable-tool (1957); unknown 1968.

Bit diameter below water level: $400 \mathrm{~mm}$ to $271 \mathrm{~m}, 298 \mathrm{~mm}$ to $347 \mathrm{~m}$.

Casing extending below water level: $308-\mathrm{mm}$ inside-diameter casing extending from land surface to $271 \mathrm{~m}$.

Total drilled depth: $271 \mathrm{~m}$ (1957); $347 \mathrm{~m}$ after the deepening in 1968.

3. Access to and description of interval for measuring water levels:

308-mm inside-diameter casing; the casing is perforated between $241-264 \mathrm{~m}$; the hole is open from 271 to $347 \mathrm{~m}$; access tube is 54-mm outside-diameter. The well produces water from the weldedtuff aquifer, located within the Topopah Spring Member of the Paintbrush Tuff.

4. Information for calculating water-level altitude:

Reference point: Top of well collar, altitude 954.54 m (surveyed by U.S. Geological Survey, 1993).

Measuring point: Top of the 54-mm outside-diameter access tube, $0.527 \mathrm{~m}$.

Depth correction for borehole deviation from vertical is not available.

5. The amount of water pumped from well J-12 in 1993 was approximately $94,600 \mathrm{~m}^{3}$ (R.A. LaCamera, U.S. Geological Survey, written commun., 1994).

\section{Water-level altitudes}

Measured water-level altitudes at well $\mathrm{J}-12$ ranged from 727.84 to $728.15 \mathrm{~m}$. Mean water-level altitude for 1993 was $727.97 \mathrm{~m}$. The mean altitude was $0.01 \mathrm{~m}$ higher than the mean altitude of $727.96 \mathrm{~m}$ for 1992 (O'Brien and others, 1995). Measured water-level altitudes are listed in table 19 and shown in figure 17. 
Table 19. Measured water-level altitudes and yearly mean water-level altitude, 1993, for well J-12

[Method: C1, Chain \#]; C2, Chain \#2; C3, Chain \#3]

\begin{tabular}{ccc}
\hline Date & $\begin{array}{c}\text { Measured water-level altitude } \\
\text { (meters, above sea level) }\end{array}$ & Method \\
\hline $01 / 19 / 93$ & 727.94 & $\mathrm{C} 1$ \\
$02 / 01 / 93$ & 727.99 & $\mathrm{C} 2$ \\
$02 / 08 / 93$ & 728.15 & $\mathrm{C} 2$ \\
$03 / 01 / 93$ & 727.94 & $\mathrm{C} 2$ \\
$03 / 08 / 93$ & 727.98 & $\mathrm{C} 2$ \\
$03 / 30 / 93$ & 727.96 & $\mathrm{C} 2$ \\
$03 / 31 / 93$ & 727.95 & $\mathrm{C} 2$ \\
$04 / 12 / 93$ & 727.99 & $\mathrm{C} 2$ \\
$04 / 28 / 93$ & 727.95 & $\mathrm{C} 2$ \\
$05 / 11 / 93$ & 728.03 & $\mathrm{C} 1$ \\
$06 / 01 / 93$ & 727.99 & $\mathrm{C} 2$ \\
$06 / 11 / 93$ & 727.99 & $\mathrm{C} 2$ \\
$06 / 29 / 93$ & 727.99 & $\mathrm{C} 2$ \\
$11 / 08 / 93$ & 727.92 & $\mathrm{C} 3$ \\
$12 / 01 / 93$ & 727.84 & $\mathrm{C} 3$ \\
$12 / 10 / 93$ & 727.92 & $\mathrm{C} 3$ \\
$12 / 30 / 93$ & 727.93 & $\mathrm{C} 3$ \\
\hline 1993 Mean $=727.97$ meters. & \\
\hline
\end{tabular}

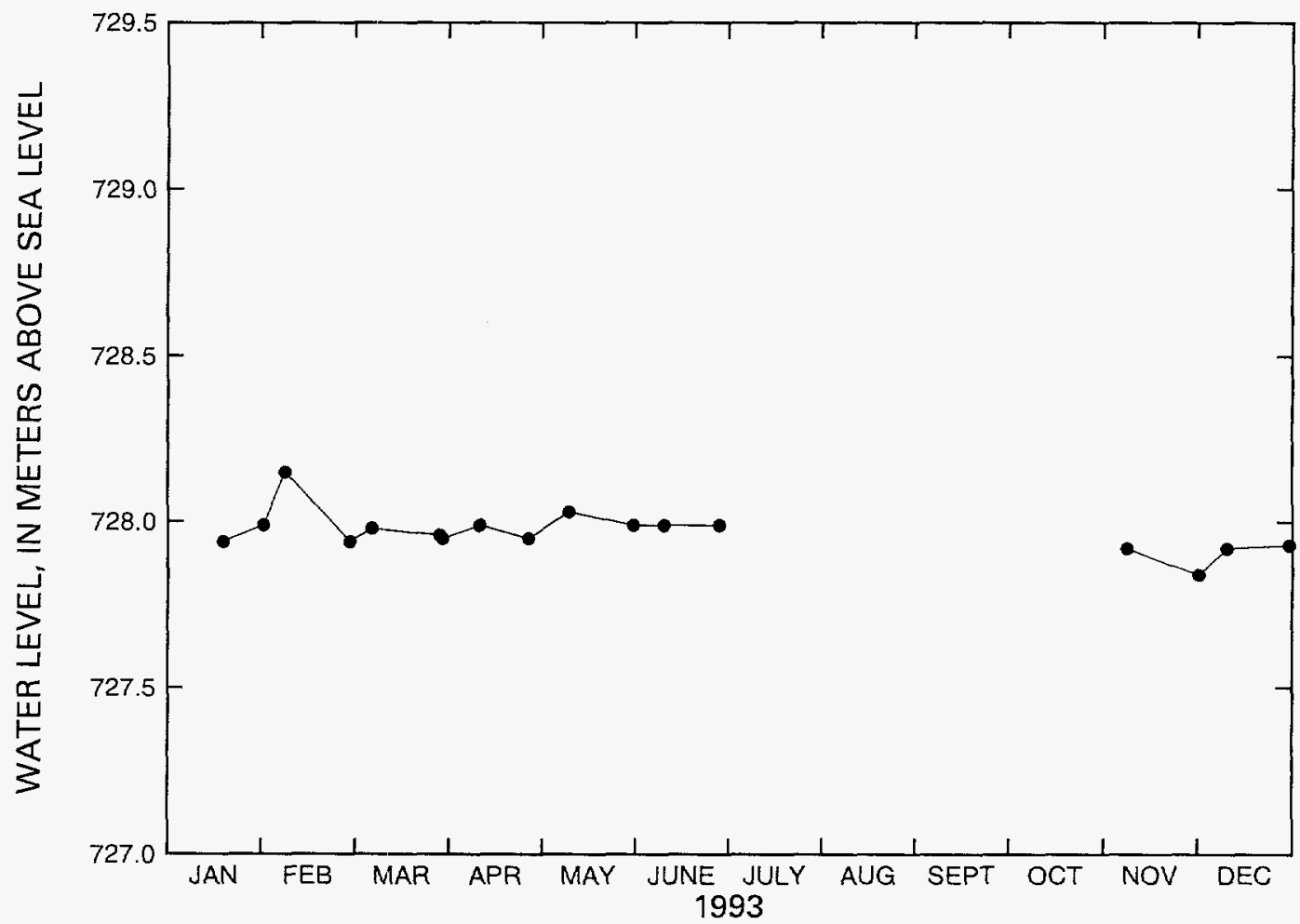

Figure 17. Water-level altitudes, 1993, for well J-12. 


\section{Well J-13}

Information about the history of well J-13 and about previous data from the well was obtained from various sources. These sources are: Robison (1984, 1986); Robison and others (1988); Holmes \& Narver, Inc. (written commun., 1986); Thordarson (1983); Young (1972); and Fenix \& Scisson (1987c). Well specifications

1. Location and identification:

Latitude and longitude: $36^{\circ} 48^{\prime} 29^{\prime \prime} \mathrm{N}$.; $116^{\circ} 23^{\prime} 40^{\prime \prime} \mathrm{W}$.

Nevada State Central Zone Coordinates (m): N 228,359; E 176,678.

U.S. Geological Survey Site ID: 364828116234001.

2. Drilling and casing information:

Well started: September 12, 1962.

Well completed: January 8, 1963.

Drilling method: Rotary, using air and aerated mud as circulating medium.

Bit diameter below water level: $438 \mathrm{~mm}$ to $402 \mathrm{~m} ; 380 \mathrm{~mm}$ from 402 to $471 \mathrm{~m} ; 194 \mathrm{~mm}$ from $471 \mathrm{~m}$ to total depth.

Casing extending below water level: $323-\mathrm{mm}$ inside diameter, from land surface to $396.5 \mathrm{~m}$; 282-mm inside diameter from 396.5 to $471.2 \mathrm{~m} ; 126-\mathrm{mm}$ inside diameter from 452.3 to 1,031.7 m; casing perforated from 303.6 to $423.7 \mathrm{~m}$ within Topopah Spring Member of Paintbrush Tuff, and from 819.9 to $1,009.5 \mathrm{~m}$ within Tram Member of Crater Flat Tuff and upper part of Lithic Ridge Tuff.

Total drilled depth: $1,063 \mathrm{~m}$.

3. Access to and description of interval for measuring water levels:

50.8-mm inside-diameter access tube, installed in 1986, in order for measuring equipment to bypass pump assembly.

4. Information for calculating water-level altitude:

Reference point: Chiseled square on concrete well collar, altitude $1,011.47 \mathrm{~m}$ (surveyed by U.S. Geological Survey, 1984).

Measuring point: Top of access tube, $0.165 \mathrm{~m}$.

Depth correction for borehole deviation from vertical is not available.

5. The amount of water pumped from well $\mathrm{J}-13$ in 1993 was approximately $157,000 \mathrm{~m}^{3}$

(R.A. LaCamera, U.S. Geological Survey, written commun., 1994).

\section{Water-level altitudes}

Measured water-level altitudes at well J-13 ranged from 728.38 to $728.69 \mathrm{~m}$. Mean-annual waterlevel altitude for 1993 was $728.47 \mathrm{~m}$. The mean altitude was $0.01 \mathrm{~m}$ higher than the mean altitude of $728.46 \mathrm{~m}$ for 1992 (O'Brien and others, 1995). Measured water-level altitudes are listed in table 20 and shown in figure 18. 
Table 20. Measured water-level altitudes and yearly mean water-level altitude, 1993, for well J-13

[Method: C1, Chain \#1; C2, Chain \#2; C3, Chain \#3]

\begin{tabular}{ccc}
\hline Date & $\begin{array}{c}\text { Measured water-level altitude } \\
\text { (meters, above sea level) }\end{array}$ & Method \\
\hline $01 / 19 / 93$ & 728.48 & $\mathrm{C} 1$ \\
$02 / 01 / 93$ & 728.45 & $\mathrm{C} 2$ \\
$02 / 08 / 93$ & 728.69 & $\mathrm{C} 2$ \\
$03 / 01 / 93$ & 728.46 & $\mathrm{C} 2$ \\
$03 / 15 / 93$ & 728.49 & $\mathrm{C} 2$ \\
$03 / 30 / 93$ & 728.47 & $\mathrm{C} 2$ \\
$04 / 21 / 93$ & 728.42 & $\mathrm{C} 2$ \\
$04 / 28 / 93$ & 728.39 & $\mathrm{C} 2$ \\
$05 / 14 / 93$ & 728.44 & $\mathrm{C} 2$ \\
$06 / 01 / 93$ & 728.50 & $\mathrm{C} 2$ \\
$06 / 11 / 93$ & 728.49 & $\mathrm{C} 2$ \\
$06 / 29 / 93$ & 728.50 & $\mathrm{C} 2$ \\
$11 / 08 / 93$ & 728.42 & $\mathrm{C} 3$ \\
$12 / 01 / 93$ & 728.38 & $\mathrm{C} 3$ \\
$12 / 10 / 93$ & 728.44 & $\mathrm{C} 3$ \\
$12 / 30 / 93$ & 728.44 & $\mathrm{C} 3$ \\
\hline
\end{tabular}

1993 Mean $=728.47$ meters.

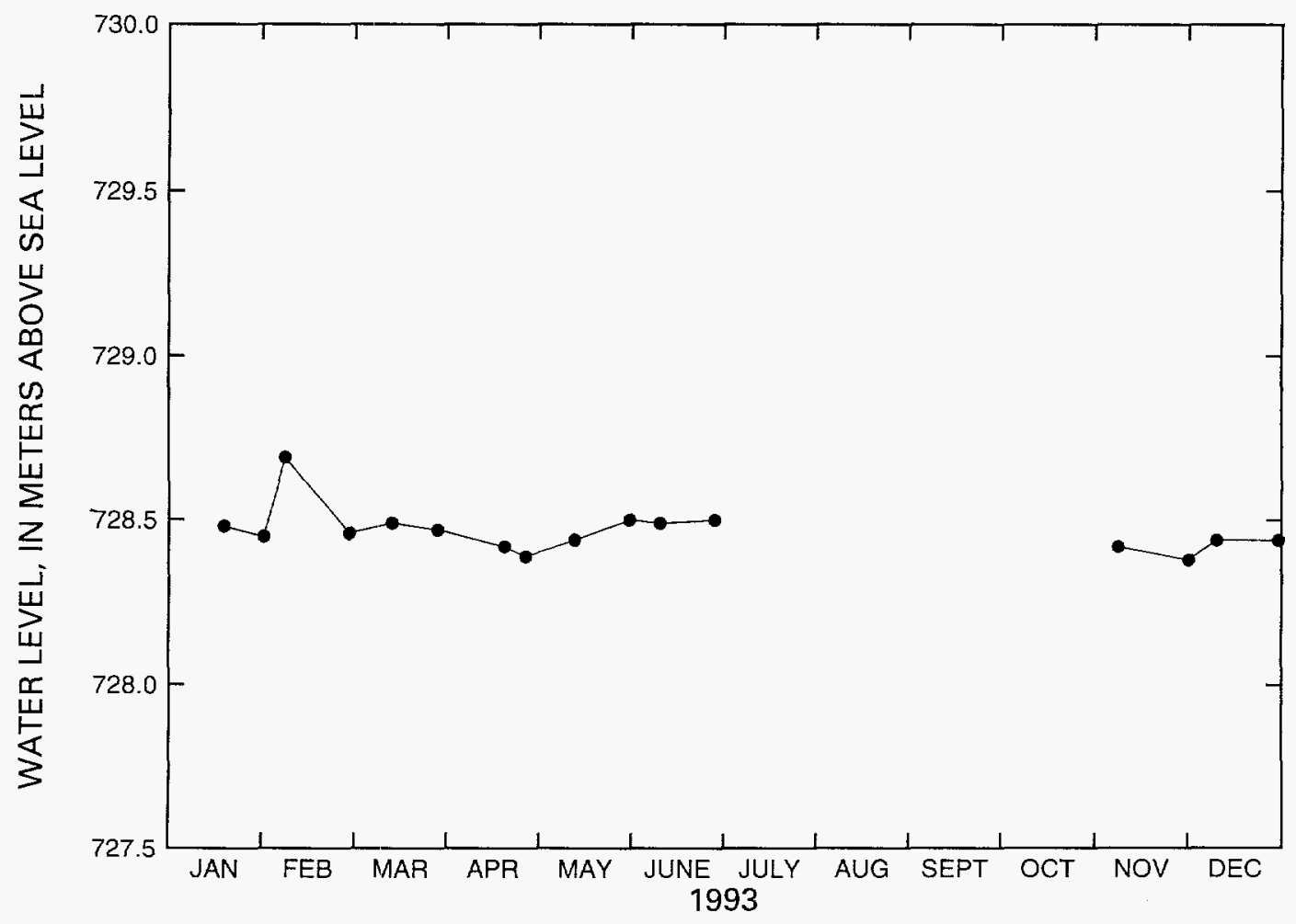

Figure 18. Water-level altitudes, 1993, for well J-13.

50 Water Levels in the Yucca Mountain Area, Nevada, 1993 


\section{Hourly Water-Level Measurements}

References or information sources, well specifications, calibration information, hydrographs of water-level altitudes, tables of mean monthly water levels and measured water-level altitudes (if appropriate) are presented for individual wells and monitored intervals in the hourly water-level network for 1993. Calibration information includes the transducer serial number, calibration date, slope of the regression line, coefficient of determination, and the water-level altitude determined at the time of calibration. Comments concerning any special conditions or information that might affect the results of the calibrations or conversion of data to water levels are included, as well as explanations for periods of missing water-level data.

Water-level altitudes are presented as annual hydrographs that were converted from the transducer data for 1993. Only those data that were evaluated as "valid" are presented. Tables are presented for each well or monitored interval of mean monthly water level. Yearly and monthly means are calculated from available daily means, regardless of amount of missing data. However, the number of missing daily means for each month is included in the tables. Daily means are not calculated if there are more than

300 consecutive minutes of missing data. Annual mean, minimum, and maximum water-level altitudes also are presented for each well or monitored interval.

\section{Well USW WT-2}

Information about the history of well USW WT-2 and about previous data from the well was obtained from various sources. These sources are: Robison $(1984,1986)$; Robison and others (1988); and Fenix \& Scisson, Inc. (1986a, 1987c).

\section{Well specifications}

1. Location and identification:

Latitude and longitude: $36^{\circ} 50^{\prime} 23^{\prime \prime} \mathrm{N}$.; $116^{\circ} 27^{\prime} 18^{\prime \prime} \mathrm{W}$.

Nevada State Central Zone Coordinates (m): N 231,849; E 171,274.

U.S. Geological Survey Site ID: 365023116271801.

2. Drilling and casing information:

Well started: July 8, 1983.

Well completed: July 16, 1983.

Drilling method: Rotary, using rock bits and air-foam circulating medium; bottom-hole core obtained.

Bit diameter below water level: $222 \mathrm{~mm}$.

Casing: Surface casing only, to a depth of $18 \mathrm{~m}$.

Total drilled depth: $628 \mathrm{~m}$.

3. Access to and description of interval for measuring water levels:

62-mm inside-diameter access tubing that has a 3.6-m-long well screen on bottom, extending from land surface to a depth of $622 \mathrm{~m}$; saturated interval of borehole within Prow Pass Member of Crater Flat Tuff.

4. Information for calculating water-level altitude:

Reference point: Top of metal tag on well casing; altitude 1,301.13 m (surveyed by

U.S. Geological Survey, 1984). 
Measuring point: Top of access tube, $0.305 \mathrm{~m}$ after 12/08/93, $0.146 \mathrm{~m}$ between $9 / 09 / 93$ and $12 / 08 / 93,0.311 \mathrm{~m}$ prior to $9 / 09 / 93$.

Depth correction for borehole deviation from vertical: $0.445 \mathrm{~m}$ after $12 / 08 / 93$ and $0.533 \mathrm{~m}$ prior to $12 / 08 / 93$, based on approximate depth to water of $571 \mathrm{~m}$.

\section{Transducer calibrations and comments}

Five calibrations of one transducer were performed during 1993. In addition, calibrations on 11/23/92 and 01/05/94 were used to calculate water-level altitudes at the beginning and end of 1993 . Results of the calibrations and measured water-level altitudes obtained during the calibrations are as follows:

\begin{tabular}{ccccc}
\hline $\begin{array}{c}\text { Transducer } \\
\text { serial number }\end{array}$ & $\begin{array}{c}\text { Calibration } \\
\text { date }\end{array}$ & $\begin{array}{c}\text { Slope } \\
(\mathbf{m} / \mathbf{m V})\end{array}$ & $\begin{array}{c}\text { Coefficient of } \\
\text { determination } \\
\left(\mathbf{r}^{2}\right)\end{array}$ & $\begin{array}{c}\text { Water-level } \\
\text { altitude } \\
(\mathbf{m})\end{array}$ \\
\hline 465819 & $11 / 23 / 92$ & 0.088 & 1.00 & 730.73 \\
465819 & $03 / 23 / 93$ & .088 & 1.00 & 730.70 \\
465819 & $07 / 23 / 93$ & .092 & 1.00 & 730.71 \\
465819 & $07 / 23 / 93$ & .088 & 1.00 & 730.71 \\
465819 & $08 / 09 / 93$ & .088 & 1.00 & 730.64 \\
465819 & $12 / 08 / 93$ & .088 & 1.00 & 730.55 \\
465819 & $01 / 05 / 94$ & .088 & 1.00 & 730.61 \\
\hline
\end{tabular}

Transducer data for 1993 generally were considered valid; however, one spike on 03/23/93, associated with a calibration, was considered invalid. No transducer data are available from 08/09/93 through $12 / 08 / 93$, because the monitoring equipment was removed from the well to allow it to be used for geophysical surveys.

\section{Water-level altitudes}

Water-level altitudes for well USW WT-2 ranged from 730.39 to $730.87 \mathrm{~m}$ above sea level in 1993 (fig. 19). The mean water-level altitude for 1993 was $730.68 \mathrm{~m}$ above sea level. This mean altitude was $0.03 \mathrm{~m}$ lower than the mean altitude of $730.71 \mathrm{~m}$ for 1992 (O'Brien and others, 1995). Mean monthly water-level altitudes are listed in table 21 . Two manual water-level measurements were obtained, using Chain \#2, while monitoring equipment was removed from the well for geophysical surveys. The water-level altitudes for those measurements, shown on figure 19, are as follows:

\begin{tabular}{cc}
\hline Date & Water-level altitude \\
\hline $09 / 09 / 93$ & $730.62 \mathrm{~m}$ \\
$10 / 21 / 93$ & $730.69 \mathrm{~m}$ \\
\hline
\end{tabular}




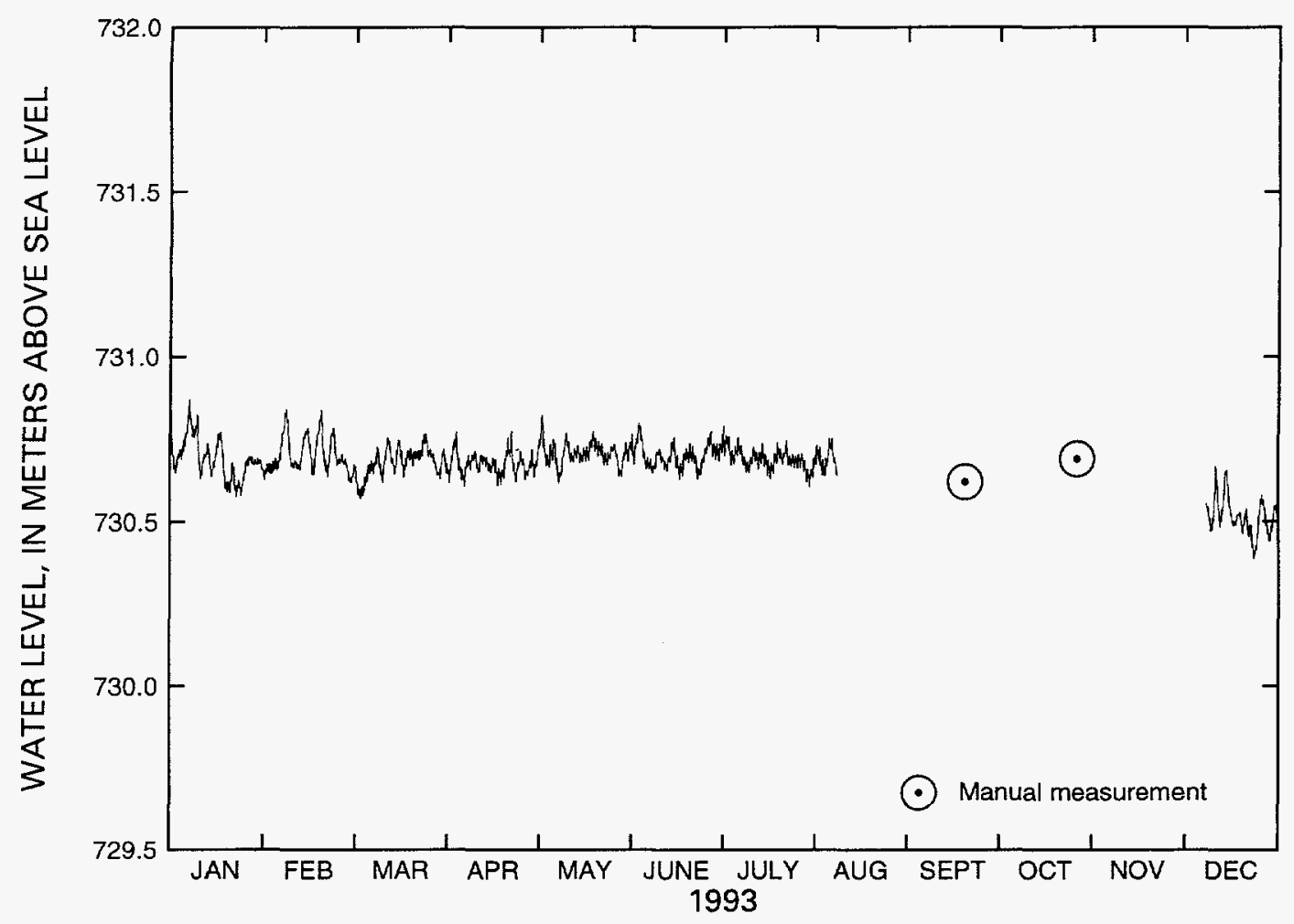

Figure 19. Water-level altitudes, 1993, for well USW WT-2.

Table 21. Mean monthly water-level altitudes, 1993 , for well USW WT-2

[NA, not available]

\begin{tabular}{lcc}
\hline Month & $\begin{array}{c}\text { Water-level altitude } \\
\text { (meters, above sea level) }\end{array}$ & $\begin{array}{c}\text { Number of missing } \\
\text { daily means }\end{array}$ \\
\hline January & 730.69 & 0 \\
February & 730.71 & 0 \\
March & 730.68 & 0 \\
April & 730.68 & 0 \\
May & 730.70 & 0 \\
June & 730.70 & 0 \\
July & 730.69 & 0 \\
August & 730.69 & 23 \\
September & NA & 30 \\
October & NA & 31 \\
November & NA & 30 \\
December & 730.51 & 8 \\
\hline
\end{tabular}




\section{Well UE-25 WT \#3}

Information about the history of well UE-25 WT \#3 and about previous data from the well was obtained from various sources. These sources are: Robison $(1984,1986)$; Robison and others (1988); and Fenix \& Scisson, Inc. (1986a, 1987c).

\section{Well specifications}

1. Location and identification:

Latitude and longitude: $36^{\circ} 47^{\prime} 57^{\prime \prime} \mathrm{N}$.; $116^{\circ} 24^{\prime} 58^{\prime \prime} \mathrm{W}$.

Nevada State Central Zone Coordinates (m): N 227,379; E 174,768.

U.S. Geological Survey Site ID: 364757116245801.

2. Drilling and casing information:

Well started: April 29, 1983.

Well completed: May 25, 1983.

Drilling method: Rotary, using rock bits and air-foam circulating medium; bottom-hole core obtained.

Bit diameter below water level: $222 \mathrm{~mm}$.

Casing: Surface casing only, to a depth of $12 \mathrm{~m}$.

Total drilled depth: $348 \mathrm{~m}$.

3. Access to and description of interval for measuring water levels:

62-mm inside-diameter tubing that has a 3.6-m-long well screen on bottom, extending from land surface to a depth of $343 \mathrm{~m}$; saturated interval of borehole within Bullfrog Member of Crater Flat Tuff.

4. Information for calculating water-level altitude:

Reference point: Top of metal tag on well casing; altitude 1,030.11 m (surveyed by U.S. Geological Survey, 1984).

Measuring point: Top of access tubing, $0.155 \mathrm{~m}$.

Depth correction for borehole deviation from vertical: $0.271 \mathrm{~m}$, based on approximate depth to water of $300 \mathrm{~m}$.

\section{Transducer calibrations and comments}

Five calibrations of one transducer were performed during 1993. In addition, calibrations on $09 / 10 / 92$ and $02 / 16 / 94$ were used to calculate water levels for 1993 . Results of the calibrations and measured water-level altitudes obtained during the calibrations are as follows:

\begin{tabular}{ccccc}
\hline $\begin{array}{c}\text { Transducer } \\
\text { serial number }\end{array}$ & $\begin{array}{c}\text { Calibration } \\
\text { date }\end{array}$ & $\begin{array}{c}\text { Slope } \\
(\mathbf{m} / \mathbf{m V})\end{array}$ & $\begin{array}{c}\text { Coefficient of } \\
\text { determination } \\
\left(\mathbf{r}^{2}\right)\end{array}$ & $\begin{array}{c}\text { Water-level } \\
\text { altitude } \\
(\mathbf{m})\end{array}$ \\
\hline 413600 & $09 / 10 / 92$ & 0.044 & 1.00 & 729.72 \\
413600 & $01 / 08 / 93$ & .044 & 1.00 & 729.78 \\
413600 & $05 / 06 / 93$ & .044 & 1.00 & 729.73 \\
413600 & $09 / 02 / 93$ & .044 & 1.00 & 729.67 \\
413600 & $10 / 18 / 93$ & .044 & 1.00 & 729.69 \\
413600 & $10 / 18 / 93$ & .044 & 1.00 & 729.69 \\
413600 & $02 / 16 / 94$ & .044 & 1.00 & 729.72 \\
\hline
\end{tabular}


No data were collected on 11/08,11/09, and 11/10/93, due to solar panel failure. The remainder of the data for 1993 are considered valid.

Water-level altitudes

Water-level altitudes for well UE-25 WT\#3 ranged from 729.61 to $729.85 \mathrm{~m}$ above sea level in 1993 (fig. 20). The mean water-level altitude for 1993 was $729.72 \mathrm{~m}$ above sea level. This mean altitude is $0.02 \mathrm{~m}$ lower than the mean altitude of $729.74 \mathrm{~m}$ for 1992 (O'Brien and others, 1995). [Mean monthly water-level altitudes for well UE-25 WT\#3 for 1992, reported by O'Brien and others (1995, table 19) were listed as $1 \mathrm{~m}$ higher than the actual mean altitudes.] Mean monthly waterlevel altitudes for 1993 are listed in table 22.

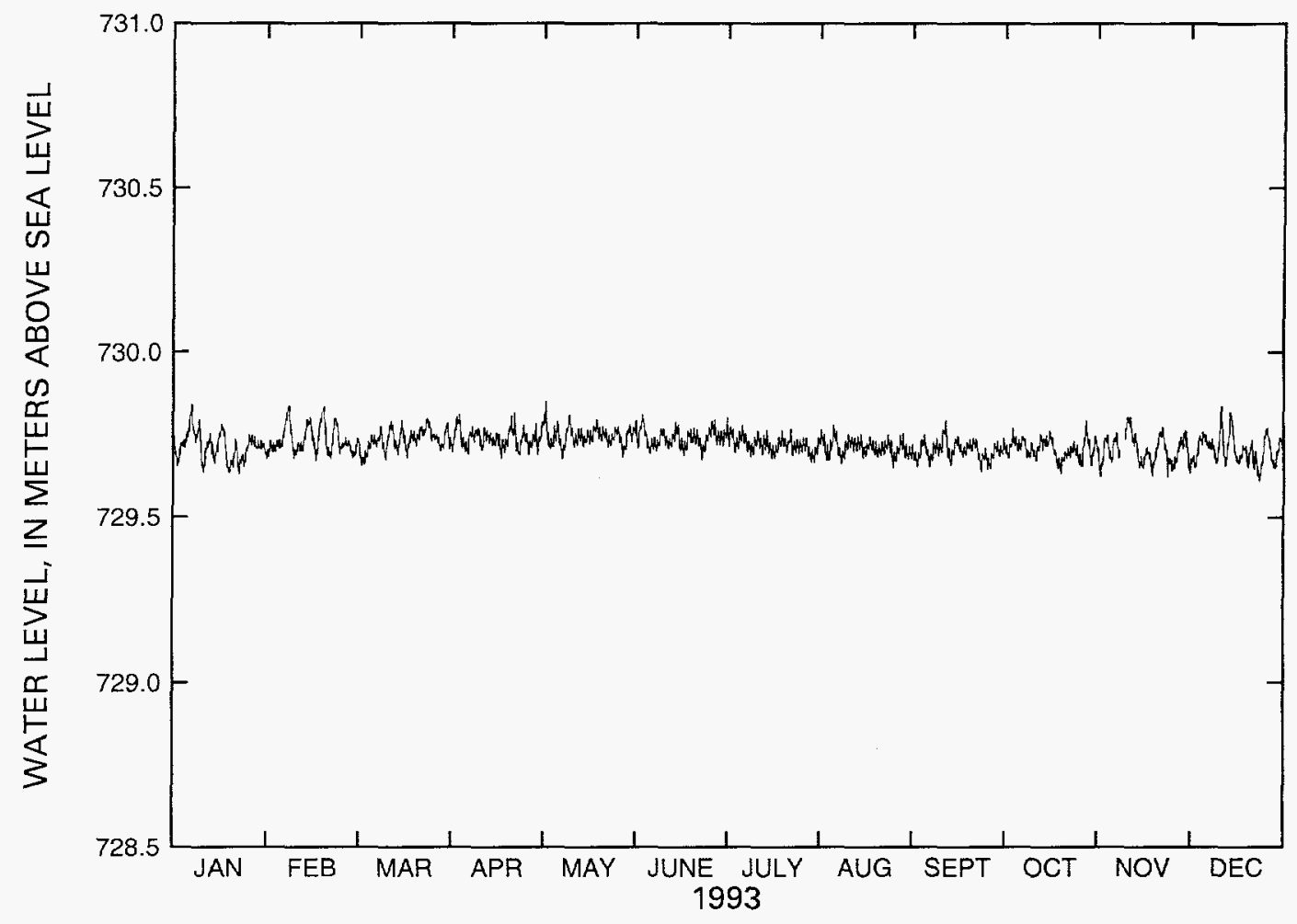

Figure 20. Water-level altitudes, 1993, for well UE-25 WT \#3. 
Table 22. Mean monthly water-level altitudes, 1993, for well UE-25 WT \#3

\begin{tabular}{lcc}
\hline Month & $\begin{array}{c}\text { Water-level altitude } \\
\text { (meters, above sea } \\
\text { level) }\end{array}$ & $\begin{array}{c}\text { Number of missing } \\
\text { daily means }\end{array}$ \\
\hline January & 729.71 & 0 \\
February & 729.74 & 0 \\
March & 729.73 & 0 \\
April & 729.74 & 0 \\
May & 729.74 & 0 \\
June & 729.74 & 0 \\
July & 729.72 & 0 \\
August & 729.71 & 0 \\
September & 729.70 & 0 \\
October & 729.71 & 0 \\
November & 729.71 & 3 \\
December & 729.70 & 0 \\
\hline
\end{tabular}

\section{Well USW WT-11}

Information about the history of well USW WT-11 and about previous data from the well was obtained from various sources. These sources are: Robison (1984, 1986); Robison and others (1988); and Fenix \& Scisson, Inc. (1986a, 1987c).

\section{Well specifications}

1. Location and identification:

Latitude and longitude: $36^{\circ} 46^{\prime} 49^{\prime \prime} \mathrm{N}$.; $116^{\circ} 28^{\prime} 02^{\prime \prime} \mathrm{W}$.

Nevada State Central Zone Coordinates (m): N 225,269; E 170,193.

U.S. Geological Survey Site ID: 364649116280201.

2. Drilling and casing information:

Well started: August 3, 1983.

Well completed: August 9, 1983.

Drilling method: Rotary, using rock bits and air-foam circulating medium; bottom-hole core obtained.

Bit diameter below water level: $222 \mathrm{~mm}$.

Casing: Surface casing only, to a depth of $14 \mathrm{~m}$.

Total drilled depth: $441 \mathrm{~m}$.

3. Access to and description of interval for measuring water levels:

62-mm inside-diameter tubing that has a 3.6-m-long well screen on bottom, extending from land surface to a depth of $416 \mathrm{~m}$; saturated interval of borehole within Topopah Spring Member of Paintbrush Tuff to tuffaceous beds of Calico Hills.

4. Information for calculating water-level altitude:

Reference point: Top of metal tag on well casing; altitude 1,094.11 m (surveyed by U.S. Geological Survey, 1984).

Measuring point: Top of access tube, $0.311 \mathrm{~m}$. 
Depth correction for borehole deviation from vertical: $0.116 \mathrm{~m}$, based on approximate depth to water of $363 \mathrm{~m}$.

\section{Transducer calibrations and comments}

Six calibrations of three transducers were performed during 1993. In addition, calibrations on 10/04/92 and 2/1/94 were used to calculate water levels at the beginning and end of 1993. Results of the calibrations and measured water-level altitudes obtained during the calibrations are as follows:

\begin{tabular}{ccccc}
\hline $\begin{array}{c}\text { Transducer } \\
\text { serial number }\end{array}$ & $\begin{array}{c}\text { Calibration } \\
\text { date }\end{array}$ & $\begin{array}{c}\text { Slope } \\
(\mathrm{m} / \mathrm{mV})\end{array}$ & $\begin{array}{c}\text { Coefficient of } \\
\text { determination } \\
\left(\mathbf{r}^{2}\right)\end{array}$ & $\begin{array}{c}\text { Water-level } \\
\text { altitude } \\
(\mathbf{m})\end{array}$ \\
\hline 308830 & $10 / 04 / 92$ & 0.085 & 1.00 & 730.65 \\
308830 & $02 / 04 / 93$ & .086 & 1.00 & 730.57 \\
308830 & $02 / 11 / 93$ & .085 & 1.00 & 730.61 \\
506113 & $02 / 11 / 93$ & .087 & 1.00 & 730.61 \\
506113 & $06 / 10 / 93$ & .086 & 1.00 & 730.72 \\
506101 & $06 / 10 / 93$ & .087 & 1.00 & 730.72 \\
506101 & $10 / 06 / 93$ & .086 & 1.00 & 730.72 \\
506101 & $02 / 01 / 94$ & .087 & 1.00 & 730.63 \\
\hline
\end{tabular}

Data are missing for $2 / 18$ to $2 / 20 / 93$, and $2 / 23$ to $2 / 28 / 93$, due to a loose wire that appeared to cause spikes, which were removed. Spikes on $3 / 1$ and $3 / 2 / 93$ were considered invalid, and removed. Missing data on $3 / 26$ to $3 / 31$ were due to a broken lead on the transducer cable. Water-levels in this well do not appear to be very responsive to earthtides or barometric pressure changes (O'Brien and others, 1995).

\section{Water-level altitudes}

Water-level altitudes for well USW WT-11 ranged from 730.51 to $730.82 \mathrm{~m}$ above sea level in 1993 (fig. 21). The mean water-level altitude for 1993 was $730.69 \mathrm{~m}$ above sea level. This mean altitude is $0.02 \mathrm{~m}$ lower than the mean altitude of $730.71 \mathrm{~m}$ for 1992 (O'Brien and others, 1995). Mean monthly water-level altitudes are listed in table 23 . 


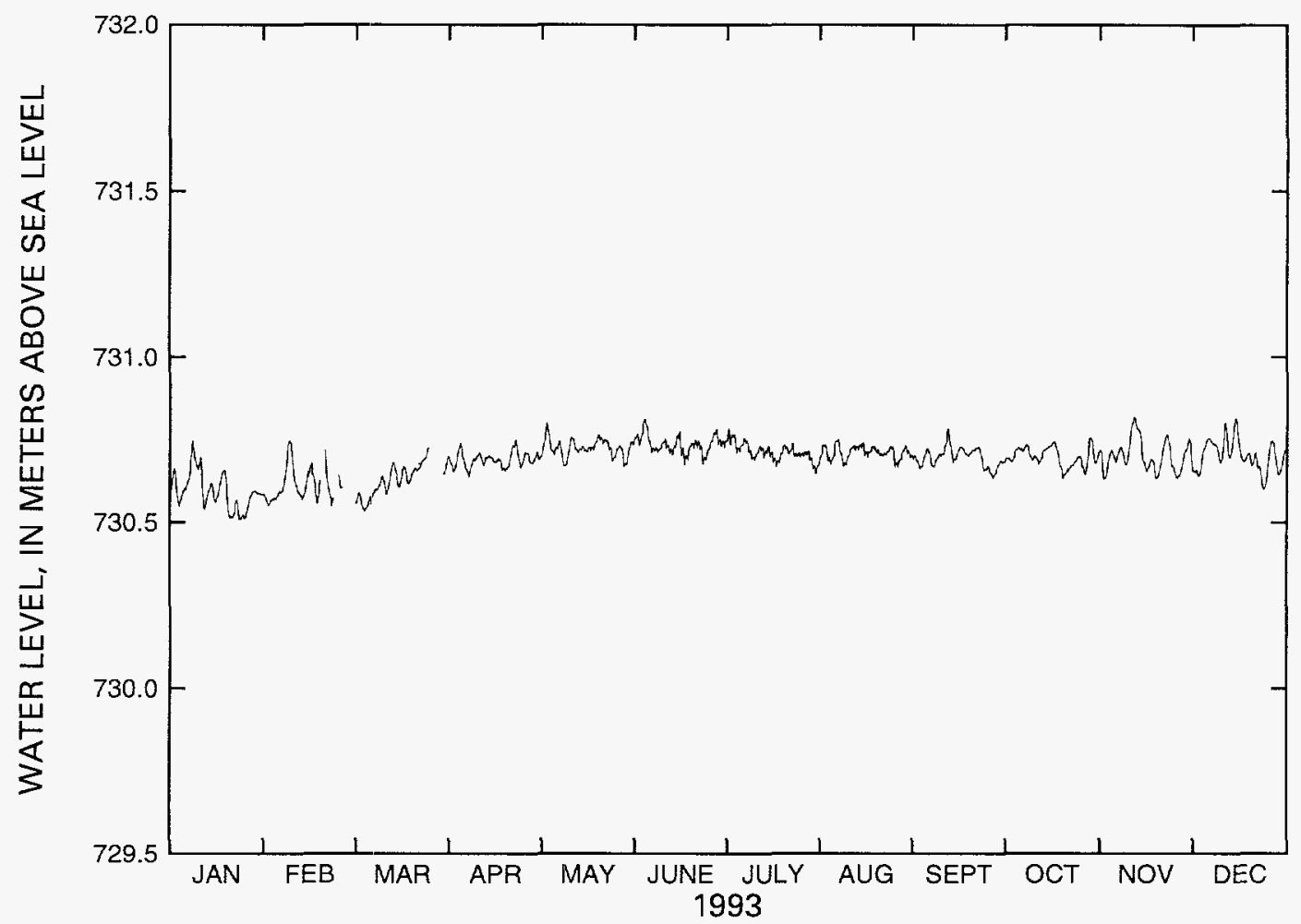

Figure 21. Water-level altitudes, 1993, for well USW WT-11.

Table 23. Mean monthly water-level altitudes, 1993, for well USW WT-11

\begin{tabular}{lcc}
\hline Month & $\begin{array}{c}\text { Water-level altitude } \\
\text { (meters, above sea level) }\end{array}$ & $\begin{array}{c}\text { Number of } \\
\text { missing daily } \\
\text { means }\end{array}$ \\
\hline January & 730.59 & 0 \\
February & 730.61 & 9 \\
March & 730.62 & 8 \\
April & 730.69 & 0 \\
May & 730.72 & 0 \\
June & 730.73 & 0 \\
July & 730.71 & 0 \\
August & 730.71 & 0 \\
September & 730.69 & 0 \\
October & 730.70 & 0 \\
November & 730.70 & 0 \\
December & 730.70 & 0 \\
\hline
\end{tabular}




\section{Well UE-25 WT \#13}

Information about the history of well UE-25 WT \#13 and about previous data from the well was obtained from various sources. These sources are: Robison $(1984,1986)$; Robison and others (1988); and Fenix \& Scisson, Inc. (1986a, 1987c).

\section{Well specifications}

1. Location and identification:

Latitude and longitude: $36^{\circ} 49^{\prime} 43^{\prime \prime} \mathrm{N}$.; $116^{\circ} 23^{\prime} 51^{\prime \prime} \mathrm{W}$.

Nevada State Central Zone Coordinates (m): N 230,647; E 176,405.

U.S. Geological Survey Site ID: 364945116235001.

2. Drilling and casing information:

Well started: June 29, 1983.

Well completed: July 7, 1983.

Drilling method: Rotary, using rock bits and air-foam circulating medium; bottom-hole core obtained.

Bit diameter below water level: $222 \mathrm{~mm}$.

Casing: Surface casing only, to a depth of $68 \mathrm{~m}$.

Total drilled depth: $354 \mathrm{~m}$.

3. Access to and description of interval for measuring water levels:

$62-\mathrm{mm}$ inside-diameter tubing that has a 3.6-m-long well screen on bottom, extending from land surface to a depth of $346 \mathrm{~m}$; saturated interval of borehole within Topopah Spring Member of Paintbrush Tuff.

4. Information for calculating water-level altitude:

Reference point: Top of metal tag on well casing; altitude $1,032.51 \mathrm{~m}$ (surveyed by U.S. Geological Survey, 1984).

Measuring point: Top of access tube, $0.305 \mathrm{~m}$.

Depth correction for borehole deviation from vertical: $0.012 \mathrm{~m}$, based on approximate depth to water of $304 \mathrm{~m}$.

\section{Transducer calibrations and comments}

Three calibrations of one transducer were performed during 1993. In addition, calibrations on $10 / 09 / 92$ and 1/27/94 were used to calculate water levels at the beginning and end of 1993 . Results of the calibrations and measured water-level altitudes obtained during the calibrations are as follows:

\begin{tabular}{ccccc}
\hline $\begin{array}{c}\text { Transducer } \\
\text { serial number }\end{array}$ & $\begin{array}{c}\text { Calibration } \\
\text { date }\end{array}$ & $\begin{array}{c}\text { Slope } \\
(\mathrm{m} / \mathrm{mV})\end{array}$ & $\begin{array}{c}\text { Coefficient of } \\
\text { determination } \\
\left(\mathrm{r}^{2}\right)\end{array}$ & $\begin{array}{c}\text { Water-level } \\
\text { altitude } \\
(\mathrm{m})\end{array}$ \\
\hline 465824 & $10 / 09 / 92$ & 0.088 & 1.00 & 729.16 \\
465824 & $02 / 05 / 93$ & .088 & 1.00 & 729.17 \\
465824 & $06 / 02 / 93$ & .089 & 1.00 & 729.07 \\
465824 & $09 / 30 / 93$ & .089 & 1.00 & 729.09 \\
465824 & $01 / 27 / 94$ & .089 & 1.00 & 729.15 \\
\hline
\end{tabular}


Transducer data from $7 / 3$ to $7 / 5 / 93$ are missing due to equipment problems. All other data for 1993 are considered valid.

\section{Water-level altitudes}

Water-level altitudes for well UE-25 WT \#13 ranged from 728.98 to $729.36 \mathrm{~m}$ above sea level in 1993 (fig. 22). The mean water-level altitude for 1993 was $729.11 \mathrm{~m}$ above sea level. This mean altitude is $0.03 \mathrm{~m}$ lower than the mean altitude of $730.14 \mathrm{~m}$ for 1992 (O'Brien and others, 1995). Mean monthly water-level altitudes are listed in table 24.

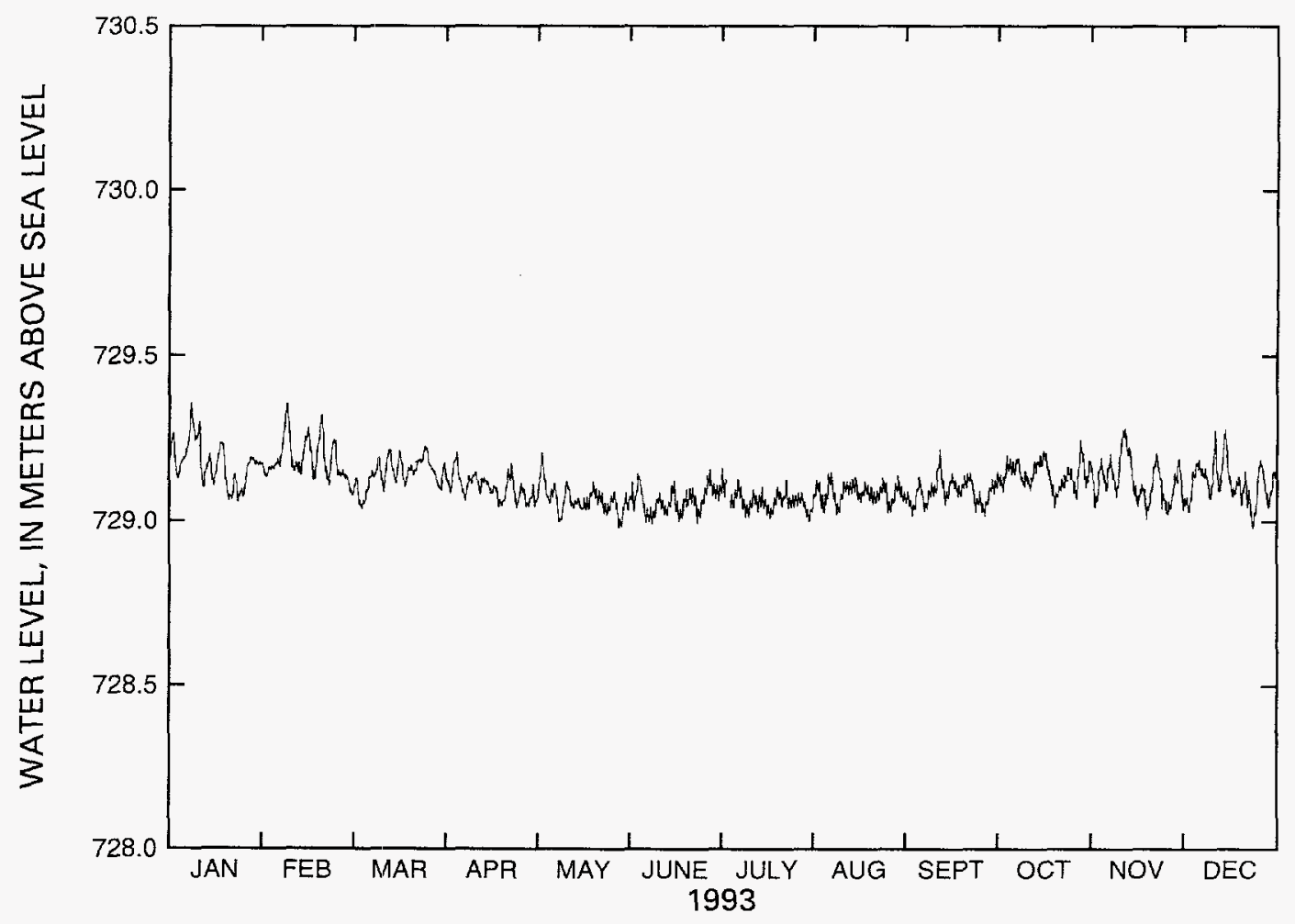

Figure 22. Water-level altitudes, 1993, for well UE-25 WT \#13. 
Table 24. Mean monthly water-level altitudes, 1993, for well UE-25 WT \#13

\begin{tabular}{lcc}
\hline Month & $\begin{array}{c}\text { Water-level altitude } \\
\text { (meters, above sea level) }\end{array}$ & $\begin{array}{c}\text { Number of missing } \\
\text { daily means }\end{array}$ \\
\hline January & 729.17 & 0 \\
February & 729.19 & 0 \\
March & 729.14 & 0 \\
April & 729.11 & 0 \\
May & 729.06 & 0 \\
June & 729.06 & 0 \\
July & 729.06 & 3 \\
August & 729.08 & 0 \\
September & 729.09 & 0 \\
October & 729.14 & 0 \\
November & 729.13 & 0 \\
December & 729.12 & 0 \\
\hline
\end{tabular}

\section{Well UE-25p \#1}

Information about the history of well UE-25p \#1 and about previous data from the well was obtained from various sources. These sources are: Craig and Johnson (1984); Craig and Robison (1984); Robison (1984, 1986); Robison and others (1988); and Fenix \& Scisson, Inc. (1986d, 1987c).

\section{Well specifications}

1. Location and identification:

Latitude and longitude: $36^{\circ} 49^{\prime} 38^{\prime \prime} \mathrm{N}$.; $116^{\circ} 25^{\prime} 21^{\prime \prime} \mathrm{W}$.

Nevada State Central Zone Coordinates (m): N 230,481; E 174,188.

U.S. Geological Survey Site ID: 364938116252102.

2. Drilling and casing information:

Well started: November 13, 1982.

Well completed: May 24, 1983.

Drilling method: Rotary, using rock bits and air-foam circulating medium; cores obtained in selected intervals.

Bit diameter below water level: $375 \mathrm{~mm}$ to $487 \mathrm{~m} ; 251 \mathrm{~mm}$ from 487 to $1,304 \mathrm{~m} ; 17 \mathrm{~mm}$ from 1,304 to $1,317 \mathrm{~m} ; 171 \mathrm{~mm}$ from 1,317 to $1,798 \mathrm{~m} ; 156 \mathrm{~mm}$ from 1,798 to $1,805 \mathrm{~m}$.

Casing extending below water level: $255-\mathrm{mm}$ inside diameter from land surface to $477 \mathrm{~m}$;

$177-\mathrm{mm}$ inside diameter from 453 to $1,297 \mathrm{~m}$; casing string is cemented in; has no perforations.

Total drilled depth: $1,805 \mathrm{~m}$.

3. Access to and description of interval for measuring water levels:

38 -mm inside-diameter tubing, open end, to depth of $418 \mathrm{~m}$; well construction is such that hydraulic head of the tuffs of Tertiary age is not monitored. Only the hydraulic head in the underlying carbonate rocks of Paleozoic age is measured (Tertiary-Paleozoic contact is at 1,244 m).

Note: A 38-mm inside-diameter tubing, closed end and filled with water, to a depth of $413 \mathrm{~m}$ below land surface, is also installed in the well to allow access for temperature logging. 
4. Information for calculating water-level altitude:

Reference point: Top of metal tag on well casing; altitude 1,114.21 m (surveyed by U.S. Geological Survey, 1984).

Measuring point: Top of access tube, $0.158 \mathrm{~m}$.

Depth correction for borehole deviation from vertical: $0.021 \mathrm{~m}$, based on approximate depth to water of $362 \mathrm{~m}$.

\section{Transducer calibrations and comments}

Five calibrations of one transducer were performed during 1993. In addition, calibrations on 11/17/92 and 3/31/94 were used to calculate water-level altitudes at the beginning and end of 1993 . Results of the calibrations and measured water-level altitudes obtained during the calibrations are as follows:

\begin{tabular}{ccccc}
\hline $\begin{array}{c}\text { Transducer } \\
\text { serial number }\end{array}$ & $\begin{array}{c}\text { Calibration } \\
\text { date }\end{array}$ & $\begin{array}{c}\text { Slope } \\
(\mathbf{m} / \mathbf{m} \mathbf{)})\end{array}$ & $\begin{array}{c}\text { Coefficient of } \\
\text { determination } \\
\left(\mathbf{r}^{2}\right)\end{array}$ & $\begin{array}{c}\text { Water-level } \\
\text { altitude } \\
(\mathbf{m})\end{array}$ \\
\hline 443988 & $11 / 17 / 92$ & 0.044 & 1.00 & 752.37 \\
443988 & $03 / 16 / 93$ & .044 & 1.00 & 752.45 \\
443988 & $03 / 17 / 93$ & .045 & 1.00 & 752.51 \\
443988 & $04 / 13 / 93$ & .044 & 1.00 & 752.50 \\
443988 & $08 / 02 / 93$ & .044 & 1.00 & 752.44 \\
443988 & $12 / 02 / 93$ & .044 & 1.00 & 752.49 \\
443988 & $03 / 31 / 94$ & .044 & 1.00 & 752.49 \\
\hline
\end{tabular}

Transducer data appeared to be very noisy; however, the data follow the barometric pressure trace and no equipment problems were found, so that the data are considered valid.

\section{Water-level altitudes}

Water-level altitudes for well UE-25p \#1 ranged from 752.31 to $752.67 \mathrm{~m}$ above sea level in 1993 (fig. 23). The mean water-level altitude for 1993 was $752.49 \mathrm{~m}$ above sea level. This mean altitude is $0.17 \mathrm{~m}$ higher than the mean altitude of $752.32 \mathrm{~m}$ for 1992 (O'Brien and others, 1995). Mean monthly water-level altitudes are listed in table 25 . 


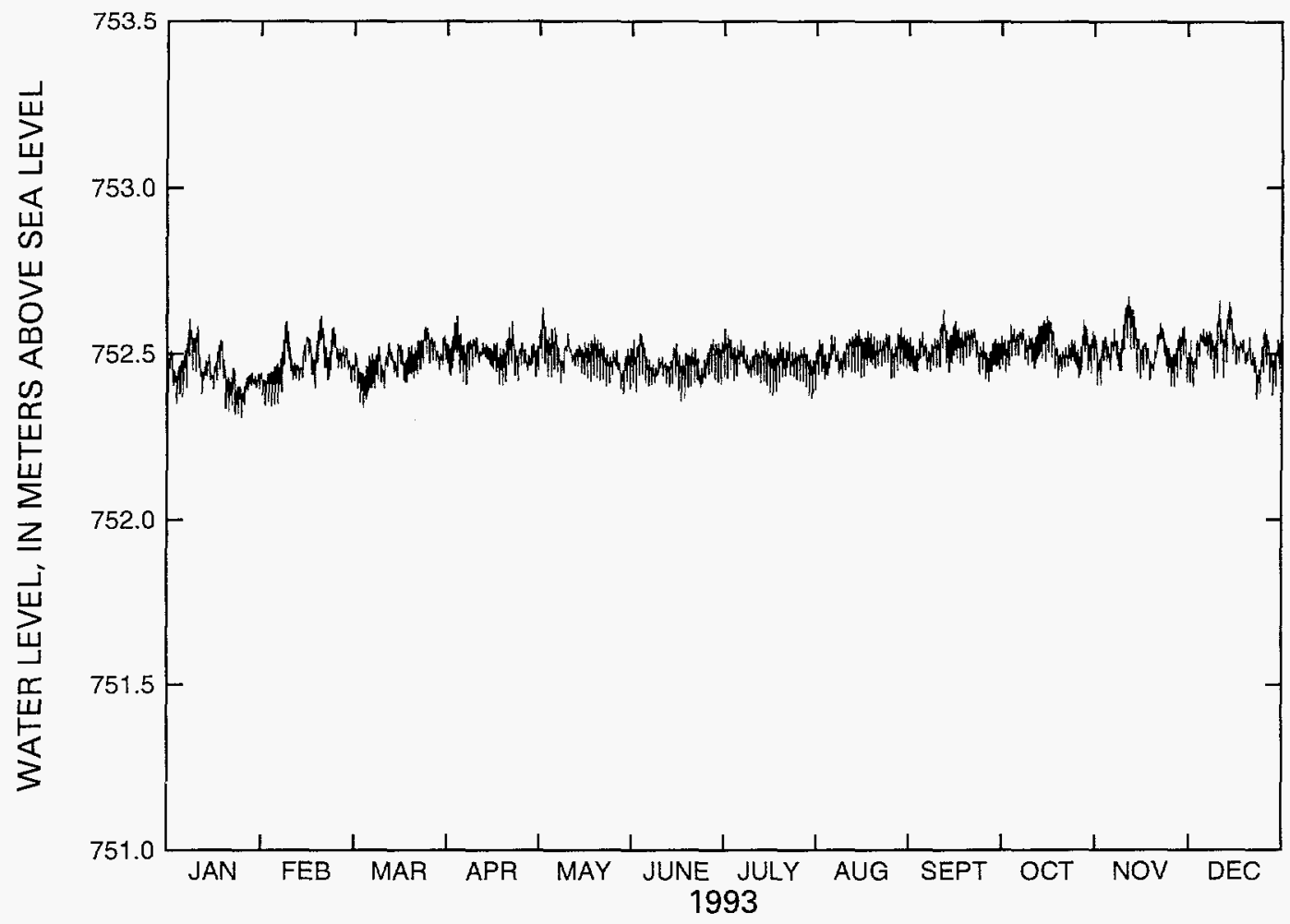

Figure 23. Water-level altitudes, 1993, for well UE-25p \#1.

Table 25. Mean monthly water-level altitudes, 1993, for well UE-25p \#1

\begin{tabular}{lcc}
\hline Month & $\begin{array}{c}\text { Water-level altitude } \\
\text { (meters, above sea level) }\end{array}$ & $\begin{array}{c}\text { Number of missing } \\
\text { daily means }\end{array}$ \\
\hline January & 752.44 & 0 \\
February & 752.48 & 0 \\
March & 752.47 & 0 \\
April & 752.50 & 0 \\
May & 752.49 & 0 \\
June & 752.46 & 0 \\
July & 752.48 & 0 \\
August & 752.50 & 0 \\
September & 752.51 & 0 \\
October & 752.17 & 0 \\
November & 752.51 & 0 \\
December & 752.51 & 0 \\
\hline
\end{tabular}




\section{Well USW G-3}

Information about the history of well USW G-3 and about previous data from the well was obtained from various sources. These sources are: Robison $(1984,1986)$; Robison and others (1988); and Fenix \& Scisson, Inc. (1987b, 1987c).

\section{Well specifications}

1. Location and identification:

Latitude and longitude: $36^{\circ} 49^{\prime} 05^{\prime \prime} \mathrm{N}$.; $116^{\circ} 28^{\prime} 01^{\prime \prime} \mathrm{W}$.

Nevada State Central Zone Coordinates (m): N 229,447; E 170,226.

U.S. Geological Survey Site ID: 364905116280101.

2. Drilling and casing information:

Well started: January 8, 1982.

Well completed: March 21, 1982.

Drilling method: Rotary, using mostly air-foam and occasional polymer added for circulating medium; many drilling problems encountered in upper part of hole, including lost circulation and lost or stuck tools; hole cored from $795 \mathrm{~m}$ to total depth.

Bit diameter below water level: $222 \mathrm{~mm}$ to $792 \mathrm{~m} ; 121 \mathrm{~mm}$ from 792 to $795 \mathrm{~m}$; $100 \mathrm{~mm}$ from $795 \mathrm{~m}$ to total depth.

Casing extending below water level: $126-\mathrm{mm}$ inside diameter to $792 \mathrm{~m}$; bottom casing tack cemented; no perforations.

Total drilled depth: $1,533 \mathrm{~m}$.

3. Access to and description of interval for measuring water levels:

Casing, 126-mm inside diameter, extending from land surface to a depth of $792 \mathrm{~m}$; saturated interval of borehole within Tram Member of the Crater Flat Tuff and the Lithic Ridge Tuff.

4. Information for calculating water-level altitude:

Reference point: Top of metal tag on well casing; altitude 1,480.47 m (surveyed by U.S. Geological Survey, 1984).

Measuring point: Top of access tube, $0.329 \mathrm{~m}$.

Depth correction for borehole deviation from vertical: $0.564 \mathrm{~m}$, based on approximate depth to water of $750 \mathrm{~m}$. 


\section{Transducer calibrations and comments}

Five calibrations of two transducers were performed during 1993. In addition, calibrations on 9/16/92 and 4/13/94 were used to calculate water-level altitudes at the beginning and end of 1993. Due to extreme borehole deviation from vertical, the water level in this well cannot be measured with steel tapes. Water levels must be measured using a multiconductor cable unit because steel tapes cannot be lowered to the water surface. Water-level altitudes are based on multiconductor cable unit measurements made on $9 / 16 / 92$ and 4/13/94. Results of the calibrations and measured water-level altitudes obtained during the calibrations are as follows:

\begin{tabular}{ccccc}
\hline $\begin{array}{c}\text { Transducer } \\
\text { serial number }\end{array}$ & $\begin{array}{c}\text { Calibration } \\
\text { date }\end{array}$ & $\begin{array}{c}\text { Slope } \\
(\mathbf{m} / \mathbf{m V})\end{array}$ & $\begin{array}{c}\text { Coefficient of } \\
\text { determination } \\
\left(\mathbf{r}^{2}\right)\end{array}$ & $\begin{array}{c}\text { Water-level } \\
\text { altitude } \\
(\mathbf{m})\end{array}$ \\
\hline 356012 & $09 / 16 / 92$ & 0.090 & 1.00 & 730.65 \\
356012 & $01 / 11 / 93$ & .088 & 1.00 & 730.57 \\
356012 & $05 / 06 / 93$ & .089 & 1.00 & 730.50 \\
356012 & $09 / 03 / 93$ & .091 & 1.00 & 730.42 \\
356012 & $12 / 16 / 93$ & .089 & 1.00 & 730.77 \\
592472 & $12 / 16 / 93$ & .090 & 1.00 & 730.77 \\
592472 & $04 / 13 / 94$ & .090 & 1.00 & 730.53 \\
\hline
\end{tabular}

Transducer data from $1 / 25$ to $1 / 30 / 93$, and on $5 / 22,5 / 23$, and $6 / 30 / 93$ were removed because of electronic problems. Water levels generally follow the trend of barometric pressure during the first nine months; however, water levels toward the end of the year appeared to drift away from the barometric trend. Whether these trends are an artifact of a malfunctioning transducer or are real could not been determined. The water levels are considered valid, largely due to a lack of any information that would deem them invalid.

\section{Water-level altitudes}

Water-level altitudes for well USW G-3 ranged from 730.37 to $730.90 \mathrm{~m}$ above sea level in 1993 (fig. 24). The mean water-level altitude for 1993 was $730.57 \mathrm{~m}$ above sea level. This mean altitude is $0.08 \mathrm{~m}$ higher than the mean altitude of $730.49 \mathrm{~m}$ for 1992 (O'Brien and others, 1995). Mean monthly water-level altitudes are listed in table 26. 


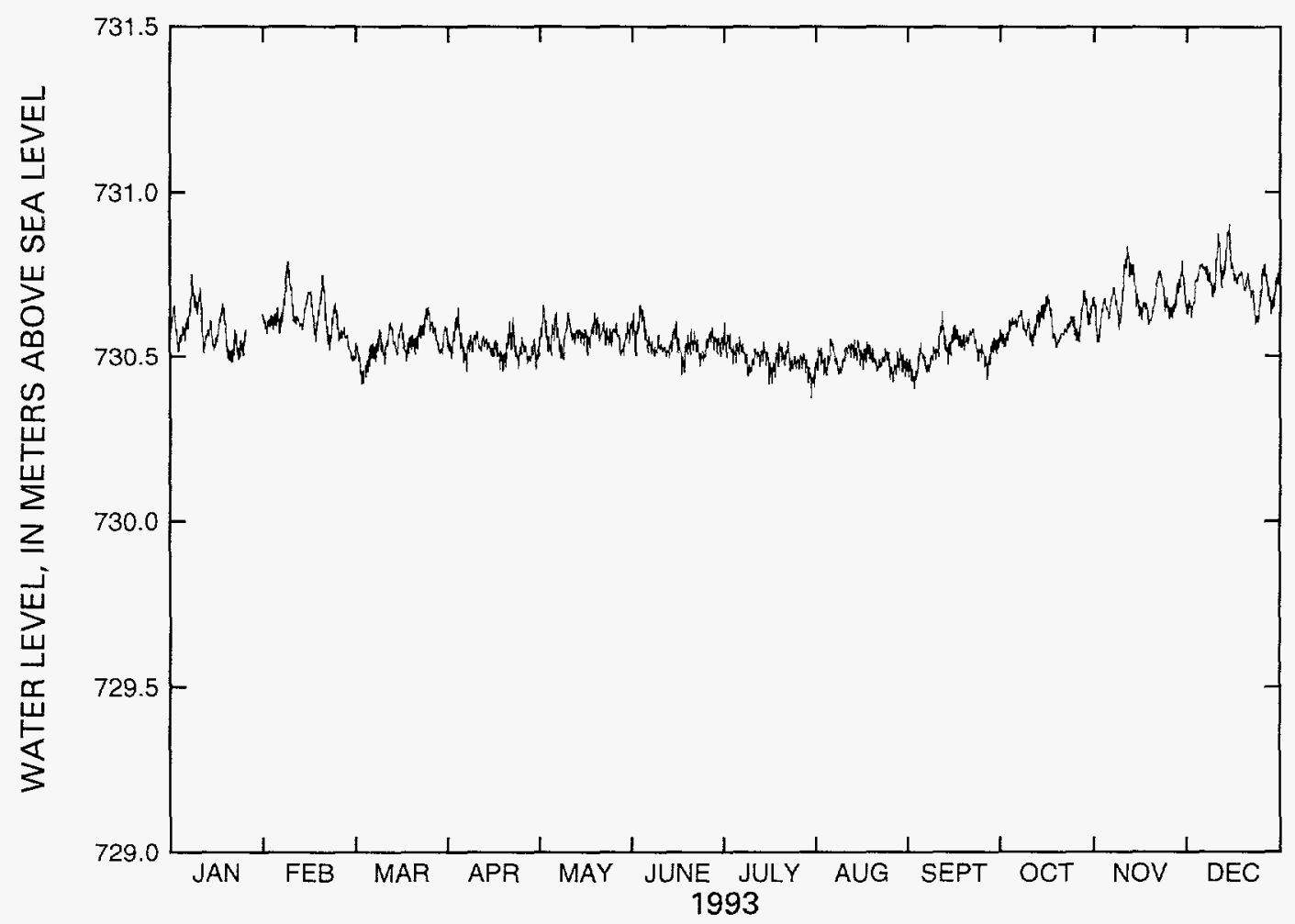

Figure 24. Water-level altitudes, 1993, for well USW G-3.

Table 26. Mean monthly water-level altitudes, 1993, for well USW G-3

\begin{tabular}{lcc}
\hline Month & $\begin{array}{c}\text { Water-level altitude } \\
\text { (meters, above sea level) }\end{array}$ & $\begin{array}{c}\text { Number of missing } \\
\text { daily means }\end{array}$ \\
\hline January & 730.58 & 7 \\
February & 730.62 & 0 \\
March & 730.54 & 0 \\
April & 730.53 & 0 \\
May & 730.56 & 2 \\
June & 730.54 & 0 \\
July & 730.50 & 1 \\
August & 730.49 & 0 \\
September & 730.52 & 0 \\
October & 730.60 & 0 \\
November & 730.68 & 0 \\
December & 730.73 & 1 \\
\hline
\end{tabular}




\section{Well USW H-1}

Information about the history of well USW H-1 and about previous data from the well was obtained from various sources. These sources are: Rush and others (1983); Rush and others (1984); Robison (1984, 1986); Robison and others (1988); and Fenix \& Scisson, Inc. (1987a, 1987c).

\section{Well specifications}

1. Location and identification:

Latitude and longitude: $36^{\circ} 51^{\prime} 57^{\prime \prime N}$.; $116^{\circ} 27^{\prime} 12^{\prime \prime} \mathrm{W}$.

Nevada State Central Zone Coordinates (m): N 234,774; E 171,416.

U.S. Geological Survey Site ID: 365157116271201.

2. Drilling and casing information:

Well started: September 3, 1980.

Well completed: January 25, 1981 (initial completion, including geophysical logging and hydraulic testing); July 6, 1982 (re-completion; four piezometers installed).

Drilling method: Rotary, using rock bits and air-foam circulating medium; cores obtained in selected intervals.

Bit diameter below water level: $311 \mathrm{~mm}$ to $688 \mathrm{~m} ; 222 \mathrm{~mm}$ from 688 to $1,829 \mathrm{~m}$.

Casing extending below water level: $226-\mathrm{mm}$ inside diameter to $687 \mathrm{~m}$. Casing string is tack cemented and perforated below the water table. See section 3 for description of intervals open to water.

Total drilled depth: $1,829 \mathrm{~m}$.

3. Access to and description of interval for measuring water levels:

Tube 1:

44-mm inside diameter, that has a 3.6-m-long well screen on bottom, extending from land surface to depth of $1,806 \mathrm{~m}$; responds to depth interval from 1,783 to $1,814 \mathrm{~m}$ within older flows and tuffs beneath the Lithic Ridge Tuff;

\section{Tube 2:}

44- $\mathrm{mm}$ inside diameter, that has a 3.6-m-long well screen on bottom, extending from land surface to depth of 1,115 m; responds to depth interval from 1,097 to 1,123 m within Tram Member of Crater Flat Tuff, and lava flow and flow breccia beneath the Tram Member;

Tube 3:

44-mm inside diameter, that has a 3.6-m-long well screen on bottom, extending from land surface to depth of $741 \mathrm{~m}$; responds to depth interval from 716 to $765 \mathrm{~m}$ within Bullfrog Member of Crater Flat Tuff;

\section{Tube 4:}

62-mm inside diameter, open ended, extending from land surface to depth of $640 \mathrm{~m}$; responds to depth interval from 572 to 673 m within Prow Pass Member of Crater Flat Tuff.

Note: During re-completion, a gravel pack was placed in the vicinity of the well screens for tubes 1,2, and 3; and other intervals were grouted with cement to ensure that the piezometers are isolated hydraulically from each other. 
4. Information for calculating water-level altitude:

Reference point: Top of metal tag on well casing; altitude 1,303.10 m (surveyed by U.S. Geological Survey, 1984).

Measuring point: Top of access tubes, $0.311 \mathrm{~m}$, all intervals.

Depth correction for borehole deviation from vertical: $0.143 \mathrm{~m}$ in tube 1 , based on approximate depth to water of $518 \mathrm{~m} ; 0.171 \mathrm{~m}$ in tube 2 , based on approximate depth to water of $567 \mathrm{~m}$;

$0.174 \mathrm{~m}$ in tubes 3 and 4, based on approximate depths to water of $572 \mathrm{~m}$.

Transducer calibrations and comments

Tube 1:

No transducers were used in tube 1 in 1993 because hourly water-level monitoring in tube 1 was discontinued on 10/27/92. Water levels were, thereafter, monitored monthly;

Tube 2:

Two calibrations of one transducer were performed during 1993. In addition, a calibration on $9 / 23 / 92$ was used to calculate water-level altitudes at the beginning of the year to $5 / 20 / 93$ when the transducer was removed. Data-collection frequency was to be monthly after the transducer was removed from the well. Three manual water-levels measurements were made during the remainder of the year. Results of the calibrations and measured water-level altitudes obtained during the calibrations are as follows:

\begin{tabular}{ccccc}
\hline $\begin{array}{c}\text { Transducer } \\
\text { serial number }\end{array}$ & $\begin{array}{c}\text { Calibration } \\
\text { date }\end{array}$ & $\begin{array}{c}\text { Slope } \\
(\mathbf{m} / \mathbf{m V})\end{array}$ & $\begin{array}{c}\text { Coefficient of } \\
\text { determination } \\
\left(\mathbf{r}^{2}\right)\end{array}$ & $\begin{array}{c}\text { Water-level } \\
\text { altitude } \\
(\mathbf{m})\end{array}$ \\
\hline 413604 & $09 / 23 / 92$ & 0.043 & 1.00 & 735.94 \\
413604 & $01 / 21 / 93$ & .043 & 1.00 & 735.92 \\
413604 & $05 / 20 / 93$ & .043 & 1.00 & 735.86 \\
\hline
\end{tabular}

Water levels in USW H-1, tube 2, have historically been insensitive to barometric pressure and earth tides; however, the transducer data for 1993 are considered valid.

\section{Tube 3:}

Three calibrations of one transducer were performed during 1993. In addition, calibrations on 9/23/92 and 1/7/94 were used to calculate water-level altitudes at the beginning and end of 1993 . Results of the calibrations and measured water-level altitudes obtained during the calibrations are as follows:

\begin{tabular}{ccccc}
\hline $\begin{array}{c}\text { Transducer } \\
\text { serial number }\end{array}$ & $\begin{array}{c}\text { Calibration } \\
\text { date }\end{array}$ & $\begin{array}{c}\text { Slope } \\
(\mathrm{m} / \mathrm{mV})\end{array}$ & $\begin{array}{c}\text { Coefficient of } \\
\text { determination } \\
\left(\mathbf{r}^{2}\right)\end{array}$ & $\begin{array}{c}\text { Water-level } \\
\text { altitude } \\
(\mathbf{m})\end{array}$ \\
\hline 255373 & $09 / 23 / 92$ & 0.090 & 1.00 & 730.62 \\
255373 & $01 / 21 / 93$ & .088 & 1.00 & 730.54 \\
255373 & $05 / 13 / 93$ & .088 & 1.00 & 730.62 \\
255373 & $09 / 09 / 93$ & .088 & 1.00 & 730.59 \\
255373 & $01 / 07 / 94$ & .087 & 1.00 & 730.70 \\
\hline
\end{tabular}


Spikes in the transducer data, probably caused by loose electrical connections, were removed for the following periods: $7 / 7$ to $7 / 9 / 93,8 / 11 / 93,08 / 12 / 93,8 / 19$ to $8 / 21 / 93,8 / 23$ to $8 / 25 / 93,8 / 27$ to $8 / 30 / 93$, and $9 / 2 / 93$.

Tube 4:

Three calibrations of one transducer were performed during 1993. In addition, calibrations on 9/23/92 and 1/06/94 were used to calculate water-level altitudes at the beginning and end of 1993 . Results of the calibrations and measured water-level altitudes obtained during the calibrations are as follows:

\begin{tabular}{ccccc}
\hline $\begin{array}{c}\text { Transducer } \\
\text { serial number }\end{array}$ & $\begin{array}{c}\text { Calibration } \\
\text { date }\end{array}$ & $\begin{array}{c}\text { Slope } \\
(\mathbf{m} / \mathbf{m V})\end{array}$ & $\begin{array}{c}\text { Coefficient of } \\
\text { determination } \\
\left(\mathbf{r}^{2}\right)\end{array}$ & $\begin{array}{c}\text { Water-level } \\
\text { altitude } \\
(\mathbf{m})\end{array}$ \\
\hline $2656 \mathrm{DJ}$ & $09 / 23 / 92$ & 0.090 & 1.00 & 730.90 \\
$2656 \mathrm{DJ}$ & $01 / 21 / 93$ & .090 & 1.00 & 730.82 \\
$2656 \mathrm{DJ}$ & $05 / 13 / 93$ & .089 & 1.00 & 730.90 \\
$2656 \mathrm{DJ}$ & $09 / 09 / 93$ & .089 & 1.00 & 730.88 \\
$2656 \mathrm{DJ}$ & $01 / 06 / 94$ & .091 & 1.00 & 730.83 \\
\hline
\end{tabular}

There appears to be minor noise in the transducer signal, but the data are considered valid. Spikes, probably caused by loose electrical connections, on the following days were removed: $3 / 5,6 / 8,8 / 11$, and $8 / 12 / 93$. A small spike on $7 / 12 / 93$ is associated with a magnitude 7.4 earthquake in the region of Hokkaido, Japan.

\section{Water-level altitudes}

Tube 1:

Water-level altitudes at well USW H-1, tube 1, ranged from 785.49 to $785.70 \mathrm{~m}$ above sea level. Mean-annual water-level altitude for 1993 was $785.58 \mathrm{~m}$. The mean altitude was $0.09 \mathrm{~m}$ lower than the mean altitude of $785.67 \mathrm{~m}$ for 1992 (O'Brien and others, 1995). Water-level altitudes are listed in table 27 and shown in figure 25.

\section{Tube 2:}

Water-level altitudes for well USW H-1, tube 2, ranged from 735.86 to $736.06 \mathrm{~m}$ above sea level in 1993 (fig. 26). The mean water-level altitude for 1993 was $735.94 \mathrm{~m}$ above sea level. This annual mean was calculated from monthly means for January through May and manual measurements for the remainder of the year. This mean altitude is $0.12 \mathrm{~m}$ lower than the mean altitude of $736.06 \mathrm{~m}$ for 1992 (O'Brien and others, 1995). [Water levels shown on figure 26 of O'Brien and others $(1995$, p. 56) are $5 \mathrm{~m}$ lower than actual values due to a drafting mistake.] Mean monthly water-level altitudes are listed in table 28. Manual measurements are as follows:

$\begin{array}{ll}05 / 20 / 93 & 735.86 \mathrm{~m} \text { above sea level, } \\ 06 / 24 / 93 & 736.06 \mathrm{~m} \text { above sea level, } \\ 11 / 19 / 93 & 735.87 \mathrm{~m} \text { above sea level, and } \\ 12 / 13 / 93 & 736.04 \mathrm{~m} \text { above sea level. }\end{array}$


Table 27. Measured water-level altitudes and yearly mean water-level altitude, 1993, for well H1, tube 1

[Method: C1, Chain \#1; C2, Chain \#2; C3, Chain \#3]

\begin{tabular}{ccc}
\hline Date & $\begin{array}{c}\text { Water-level altitude } \\
\text { (meters, above sea level) }\end{array}$ & Method \\
\hline $01 / 21 / 93$ & 785.49 & $\mathrm{C} 1$ \\
$02 / 17 / 93$ & 785.51 & $\mathrm{C} 2$ \\
$03 / 24 / 93$ & 785.50 & $\mathrm{C} 2$ \\
$04 / 21 / 93$ & 785.55 & $\mathrm{C} 2$ \\
$05 / 13 / 93$ & 785.63 & $\mathrm{C} 2$ \\
$06 / 24 / 93$ & 785.56 & $\mathrm{C} 2$ \\
$11 / 19 / 93$ & 785.70 & $\mathrm{C} 3$ \\
$12 / 13 / 93$ & 785.67 & $\mathrm{C} 3$ \\
\hline
\end{tabular}

1993 Mean $=785.58$ meters.

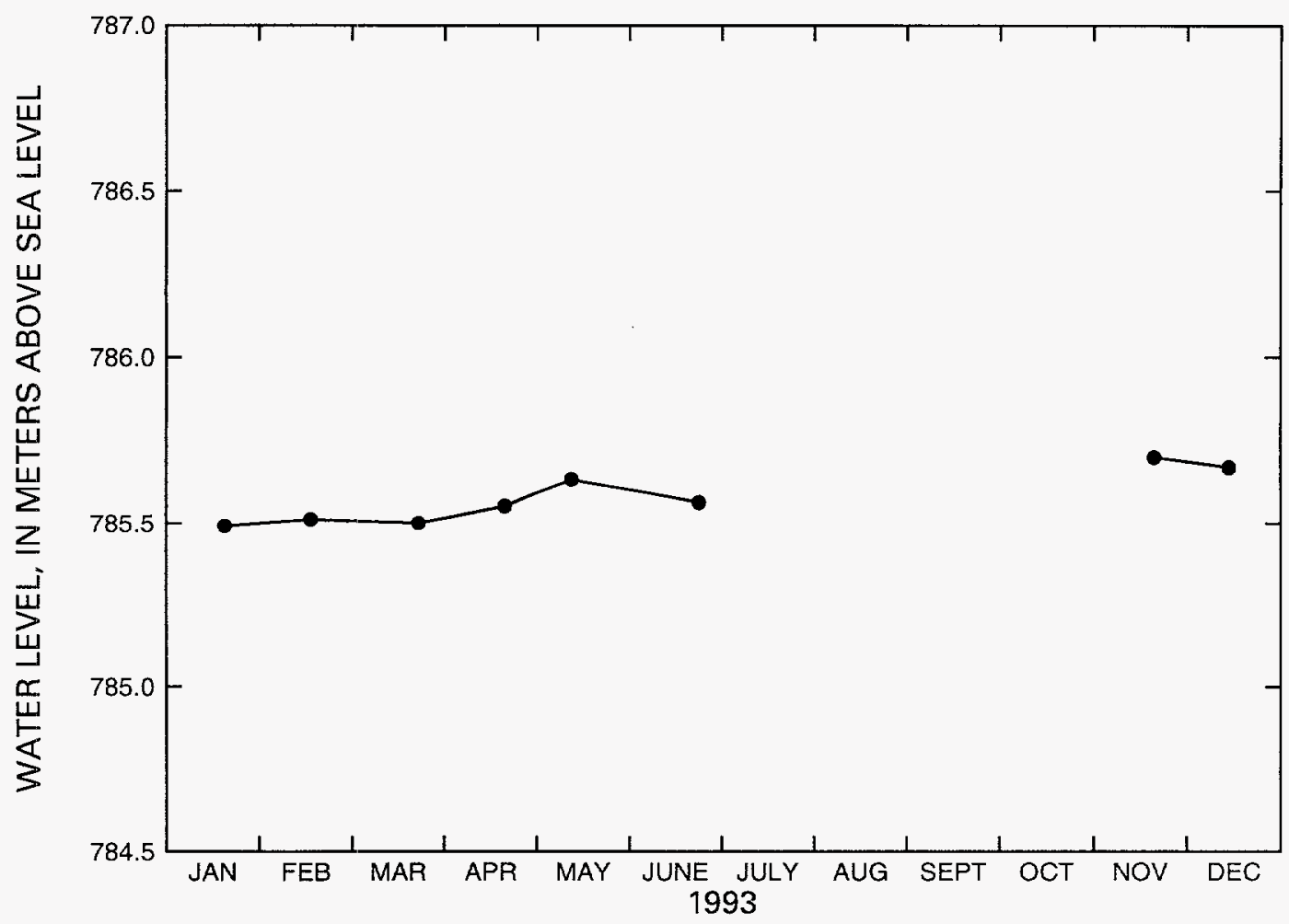

Figure 25. Water-level altitudes, 1993, for well USW H-1, tube 1. 


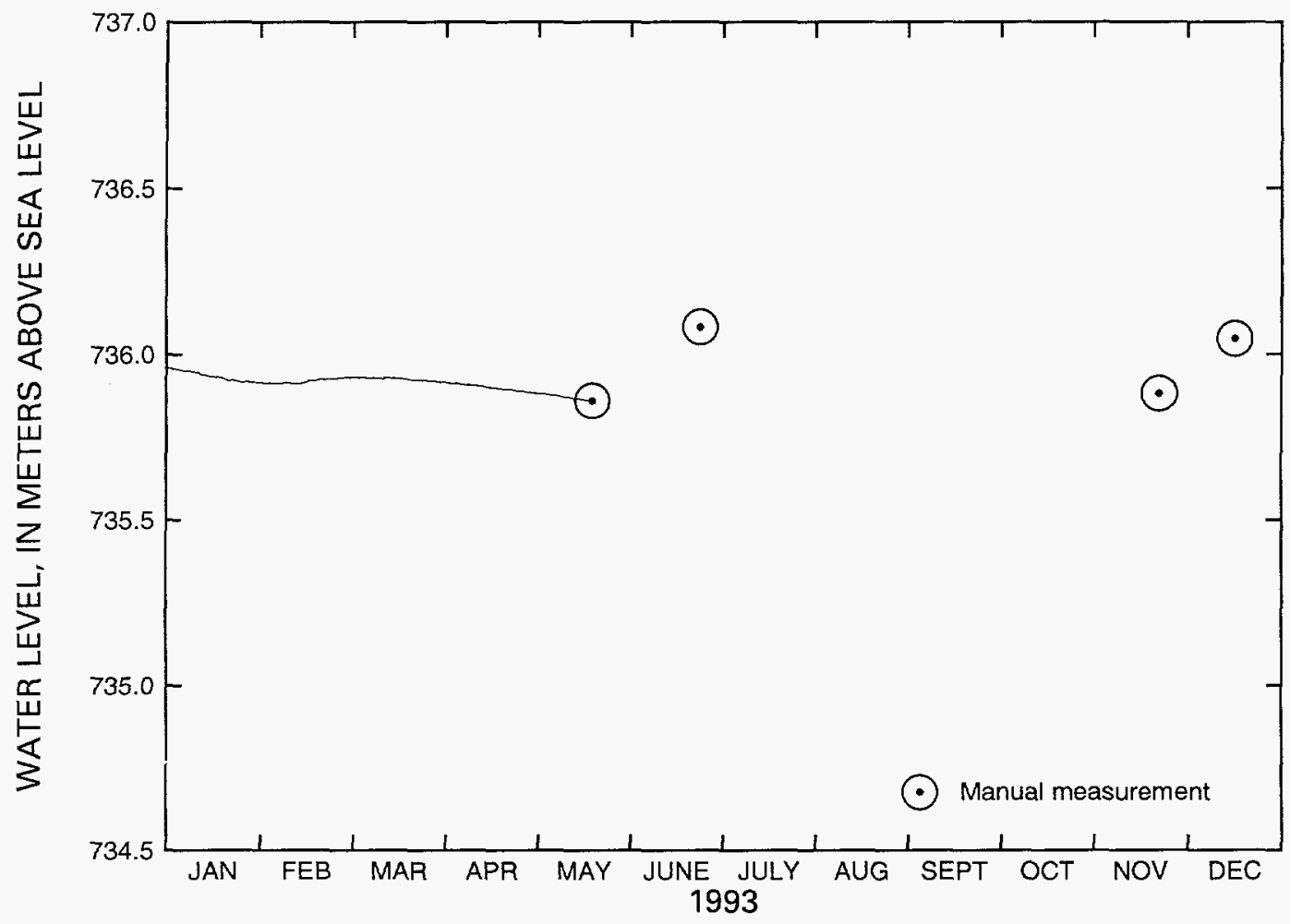

Figure 26. Water-level altitudes, 1993, for well USW H-1, tube 2.

Table 28. Mean monthly water-level altitudes, 1993, for well USW H-1, tube 2

[NA, not available]

\begin{tabular}{lcc}
\hline Month & $\begin{array}{c}\text { Water-level altitude } \\
\text { (meters, above sea level) }\end{array}$ & $\begin{array}{c}\text { Number of missing } \\
\text { daily means }\end{array}$ \\
\hline January & 735.93 & 0 \\
February & 735.92 & 0 \\
March & 735.93 & 0 \\
April & 735.90 & 0 \\
May & 735.87 & 12 \\
June & NA & \\
July & NA & \\
August & NA & \\
September & NA & \\
October & NA & \\
November & NA & \\
December & NA & \\
\hline
\end{tabular}




\section{Tube 3:}

Water-level altitudes for well USW H-1, tube 3, ranged from 730.50 to $730.86 \mathrm{~m}$ above sea level in 1993 (fig. 27). The mean water-level altitude for 1993 was 730.64 above sea level. This mean altitude is $0.07 \mathrm{~m}$ lower than the mean altitude of $730.71 \mathrm{~m}$ for 1992 (O'Brien and others, 1995). Mean monthly water-level altitudes are listed in table 29.

Tube 4:

Water-level altitudes for well USW H-1, tube 4, ranged from 730.72 to $731.11 \mathrm{~m}$ above sea level in 1993 (fig. 28). The mean water-level altitude for 1993 was $730.90 \mathrm{~m}$ above sea level. This mean altitude is $0.03 \mathrm{~m}$ lower than the mean altitude of $730.93 \mathrm{~m}$ for 1992 (O'Brien and others, 1995). Mean monthly water-level altitudes are listed in table 30.

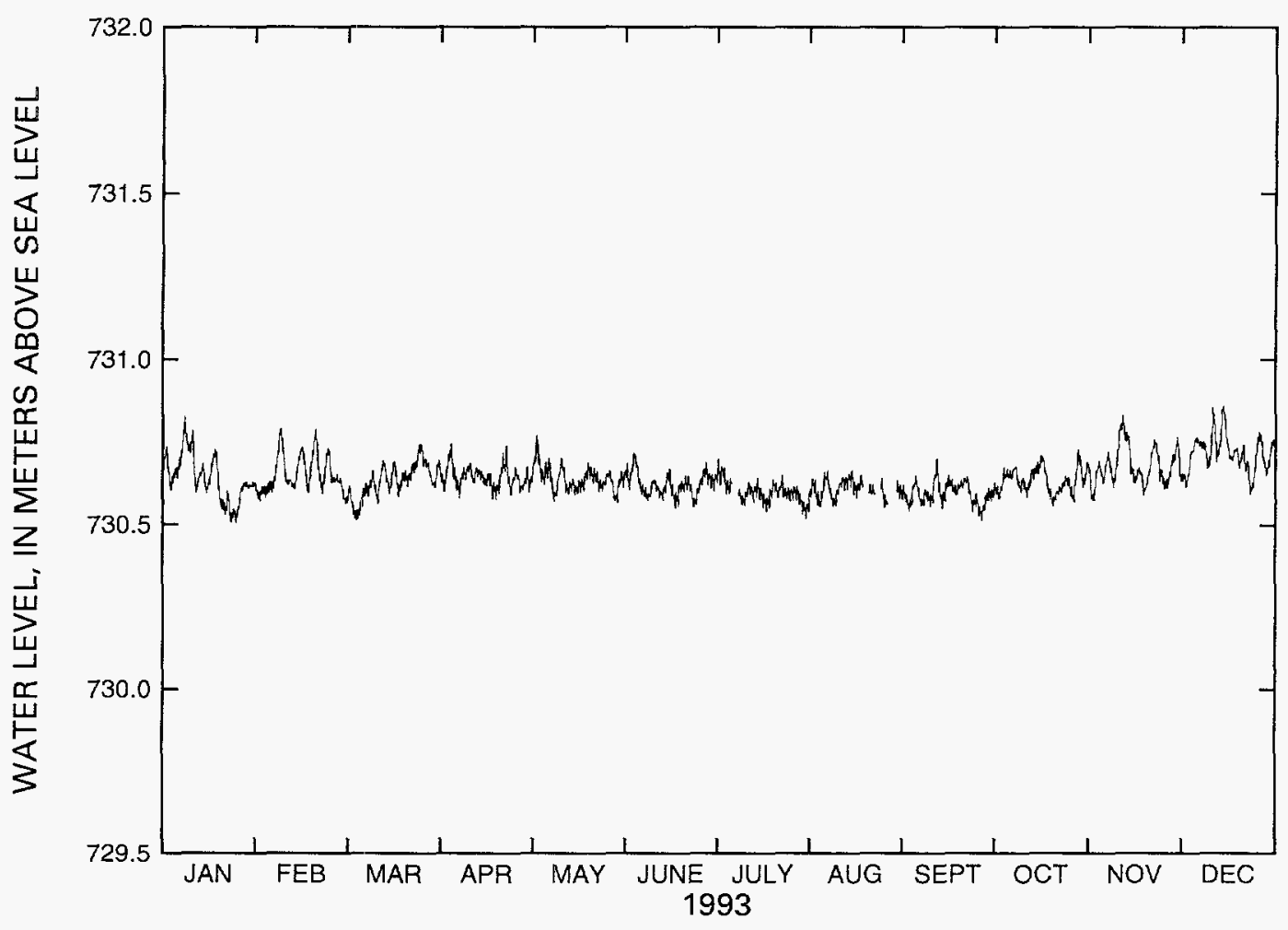

Figure 27. Water-level altitudes, 1993, for well USW H-1, tube 3. 
Table 29. Mean monthly water-level altitudes, 1993, for well USW $\mathrm{H}-1$, tube 3

\begin{tabular}{lcc}
\hline Month & $\begin{array}{c}\text { Water-level altitude } \\
\text { (meters, above sea level) }\end{array}$ & $\begin{array}{c}\text { Number of missing } \\
\text { daily means }\end{array}$ \\
\hline January & 730.64 & 0 \\
February & 730.66 & 0 \\
March & 730.63 & 0 \\
April & 730.65 & 0 \\
May & 730.64 & 0 \\
June & 730.62 & 0 \\
July & 730.60 & 3 \\
August & 730.61 & 12 \\
September & 730.60 & 1 \\
October & 730.63 & 0 \\
November & 730.68 & 0 \\
December & 730.72 & 0 \\
\hline
\end{tabular}

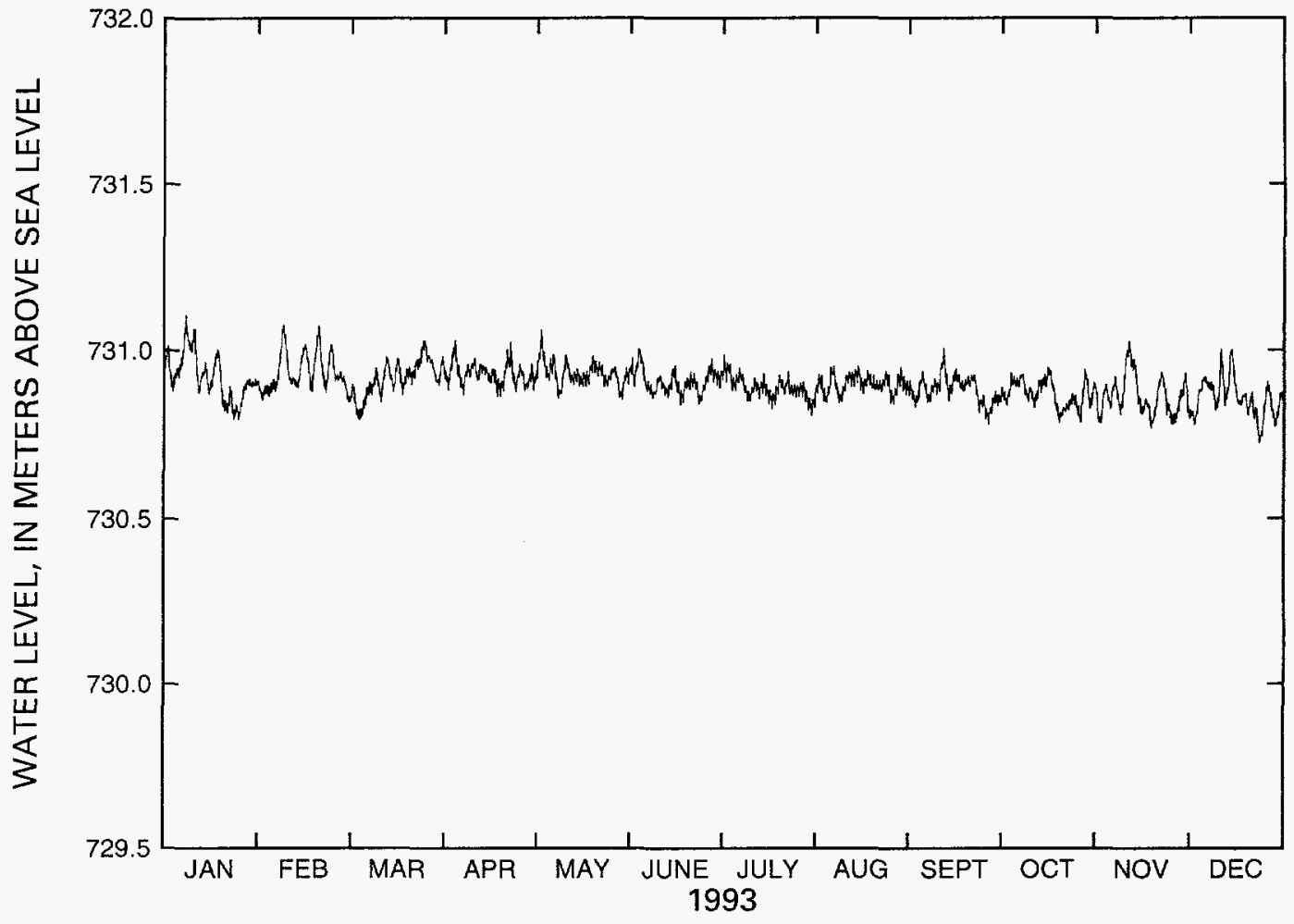

Figure 28. Water-level altitudes, 1993, for well USW H-1, tube 4. 
Table 30. Mean monthly water-level altitudes, 1993, for well USW $\mathrm{H}-1$, tube 4

\begin{tabular}{lcc}
\hline Month & $\begin{array}{c}\text { Water-level altitude } \\
\text { (meters, above sea level) }\end{array}$ & $\begin{array}{c}\text { Number of missing } \\
\text { daily means }\end{array}$ \\
\hline January & 730.92 & 0 \\
February & 730.94 & 0 \\
March & 730.91 & 0 \\
April & 730.93 & 0 \\
May & 730.93 & 0 \\
June & 730.91 & 0 \\
July & 730.89 & 0 \\
August & 730.90 & 0 \\
September & 730.88 & 0 \\
October & 730.87 & 0 \\
November & 730.86 & 0 \\
December & 730.85 & 0 \\
\hline
\end{tabular}

\section{Well USW H-3}

Information about the history of well USW H-3 and about previous data from the well was obtained from various sources. These sources are: Thordarson, Rush, Spengler, and Waddell (1984); Thordarson, Rush, and Waddell (1984); Robison (1984, 1986); Robison and others (1988); and Fenix \& Scisson, Inc. $(1987 \mathrm{a}, 1987 \mathrm{c})$.

\section{Well specifications}

1. Location and identification:

Latitude and longitude: $36^{\circ} 49^{\prime} 42^{\prime \prime} \mathrm{N}$.; $116^{\circ} 28^{\prime} 00^{\prime \prime} \mathrm{W}$.

Nevada State Central Zone Coordinates (m): N 230,594; E 170,216.

U.S. Geological Survey Site ID: 364942116280001.

2. Drilling and casing information:

Well started: January 27, 1982.

Well completed: March 19, 1982.

Drilling method: Rotary, using rock bits and air-foam circulating medium.

Bit diameter below water level: $375 \mathrm{~mm}$ to $808 \mathrm{~m} ; 222 \mathrm{~m}$ from 808 to $1,219 \mathrm{~m}$.

Casing extending below water level: $253 \mathrm{~mm}$ diameter to $792 \mathrm{~m}$, not perforated below the water level.

Total drilled depth: $1,219 \mathrm{~m}$.

3. Access to and description of intervals for measuring water levels:

\section{Upper interval:}

41-mm inside-diameter open-ended tubing, extending from land surface to depth of about $762 \mathrm{~m}$; upper interval of well, from near water table to top of inflatable packer, within bedded tuff and Tram Member of Crater Flat Tuff. 


\section{Lower interval:}

62-mm inside-diameter tubing that has an inflatable packer on bottom end extending from land surface to $1,114 \mathrm{~m}$; lower interval from below packer to bottom of well within Lithic Ridge Tuff.

Note: Inflatable packer installed January 1983 at a depth of $1,190 \mathrm{~m}$; removed late November 1983 during period of additional hydraulic testing; re-installed in May 1984 at depth of $1,114 \mathrm{~m}$.

4. Information for calculating water-level altitude:

Reference point: Top of metal tag on well casing; altitude $1483.47 \mathrm{~m}$ (surveyed by U.S. Geological Survey, 1984).

Measuring point: Top of access tubes, $0.174 \mathrm{~m}$, upper interval; $0.201 \mathrm{~m}$, lower interval.

Depth correction for borehole deviation from vertical: $0.079 \mathrm{~m}$, upper interval, based on - approximate depth to water of $752 \mathrm{~m} ; 0.058 \mathrm{~m}$, lower interval, based on approximate depth to water of $728 \mathrm{~m}$.

\section{Transducer calibrations and comments}

\section{Upper interval:}

Four calibrations of one transducer were performed during 1993. In addition, calibrations on 12/09/92 and 3/22/94 were used to calculate water-level altitudes at the beginning and end of 1993 . Results of the calibrations and measured water-level altitudes obtained during the calibrations are as follows:

\begin{tabular}{ccccc}
\hline $\begin{array}{c}\text { Transducer } \\
\text { serial number }\end{array}$ & $\begin{array}{c}\text { Calibration } \\
\text { date }\end{array}$ & $\begin{array}{c}\text { Slope } \\
(\mathbf{m} / \mathbf{m V})\end{array}$ & $\begin{array}{c}\text { Coefficient of } \\
\text { determination } \\
\left(\mathbf{r}^{\mathbf{2}}\right)\end{array}$ & $\begin{array}{c}\text { Water-level } \\
\text { altitude } \\
(\mathbf{m})\end{array}$ \\
\hline 264709 & $12 / 09 / 92$ & 0.089 & 1.00 & 731.18 \\
264709 & $04 / 07 / 93$ & .089 & 1.00 & 731.15 \\
264709 & $07 / 22 / 93$ & .090 & 1.00 & 731.22 \\
264709 & $07 / 22 / 93$ & .089 & 1.00 & 731.22 \\
264709 & $11 / 23 / 93$ & .090 & 1.00 & 731.28 \\
264709 & $03 / 22 / 94$ & .090 & 1.00 & 731.33 \\
\hline
\end{tabular}

Data missing on 1/28/93 are due to a calibration and water-level measurements made in lower zone.

\section{Lower interval:}

Five calibrations of one transducer were performed during 1993. In addition, calibrations on 10/2/92 and 3/22/94 were used to calculate water-level altitudes at the beginning and end of 1993 . Results of the calibrations and measured water-level altitudes obtained during the calibrations are as follows: 


\begin{tabular}{ccccc}
\hline $\begin{array}{c}\text { Transducer } \\
\text { serial number }\end{array}$ & $\begin{array}{c}\text { Calibration } \\
\text { date }\end{array}$ & $\begin{array}{c}\text { Slope } \\
(\mathbf{m} / \mathbf{m V})\end{array}$ & $\begin{array}{c}\text { Coefficient of } \\
\text { determination } \\
\left(\mathbf{r}^{2}\right)\end{array}$ & $\begin{array}{c}\text { Water level } \\
\text { altitude } \\
(\mathbf{m})\end{array}$ \\
\hline 264707 & $10 / 02 / 92$ & 0.086 & 1.00 & 755.48 \\
264707 & $01 / 28 / 93$ & .087 & 1.00 & 756.11 \\
264707 & $05 / 25 / 93$ & .087 & 1.00 & 756.70 \\
264707 & $09 / 22 / 93$ & .087 & 1.00 & 757.21 \\
264707 & $11 / 03 / 93$ & .085 & 1.00 & 757.29 \\
264707 & $11 / 23 / 93$ & .087 & 1.00 & 757.45 \\
264707 & $03 / 22 / 94$ & .087 & 1.00 & 757.87 \\
\hline
\end{tabular}

Data associated with calibrations on $1 / 28,11 / 03$, and $11 / 23 / 93$, were not converted to water levels. A spike on $8 / 12 / 93$ was removed because there are no supporting data to indicate that this fluctuation was real. Spikes on 11/03 and 11/23/93 associated with calibrations were removed.

\section{Water-level altitudes}

\section{Upper interval:}

Water-level altitudes for well USW H-3, upper interval, ranged from 731.06 to $731.41 \mathrm{~m}$ above sea level in 1993 (fig. 29). The mean water-level altitude for 1993 was $731.21 \mathrm{~m}$ above sea level. This mean altitude is $0.02 \mathrm{~m}$ lower than the mean altitude of $731.23 \mathrm{~m}$ for 1992 (O'Brien and others, 1995). Mean monthly water-level altitudes are listed in table 31.

\section{Lower interval:}

Water-level altitudes for well USW H-3, lower interval, ranged from 755.95 to $757.64 \mathrm{~m}$ above sea level in 1993 (fig. 30). The mean water-level altitude for 1993 was $756.83 \mathrm{~m}$ above sea level. This mean altitude is $2.13 \mathrm{~m}$ higher than the mean altitude of $754.70 \mathrm{~m}$ for 1992 (O'Brien and others, 1995). The inflatable packer, which divides the well into two intervals, was moved to a different location on 12/14/90. The water level in the lower interval has been rising, in the process of reaching equilibration, to a new static water-level since that time. Mean monthly water-level altitudes are listed in table 32. 


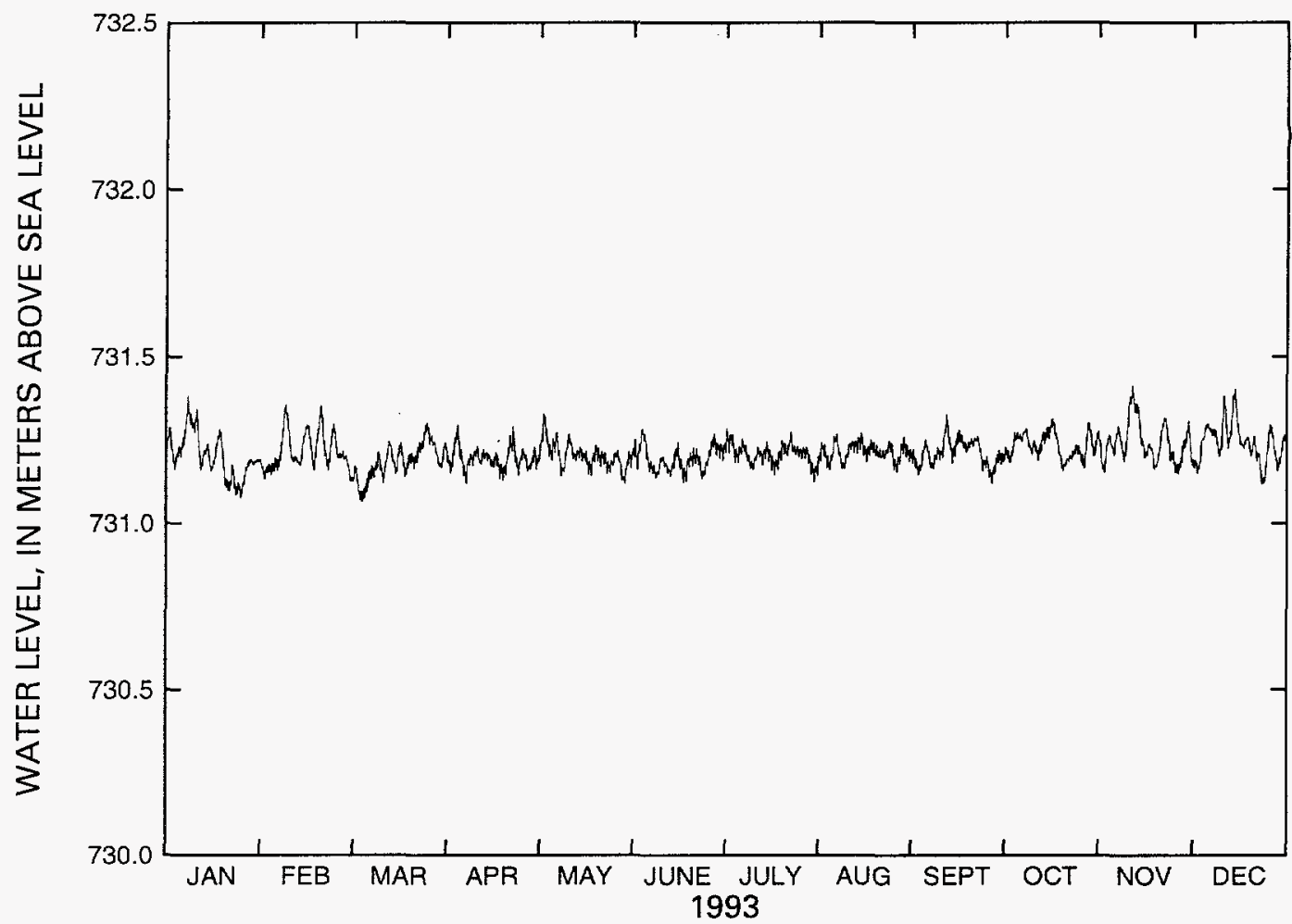

Figure 29. Water-level altitudes, 1993, for well USW H-3, upper interval.

Table 31. Mean monthly water-level altitudes, 1993, for well USW H-3, upper interval

\begin{tabular}{lcc}
\hline Month & $\begin{array}{c}\text { Water-level altitude } \\
\text { (meters, above sea level) }\end{array}$ & $\begin{array}{c}\text { Number of missing } \\
\text { daily means }\end{array}$ \\
\hline January & 731.20 & 1 \\
February & 731.22 & 0 \\
March & 731.18 & 0 \\
April & 731.20 & 0 \\
May & 731.20 & 0 \\
June & 731.19 & 0 \\
July & 731.21 & 0 \\
August & 731.21 & 0 \\
September & 731.21 & 0 \\
October & 731.23 & 0 \\
November & 731.24 & 0 \\
December & 731.24 & 0 \\
\hline
\end{tabular}




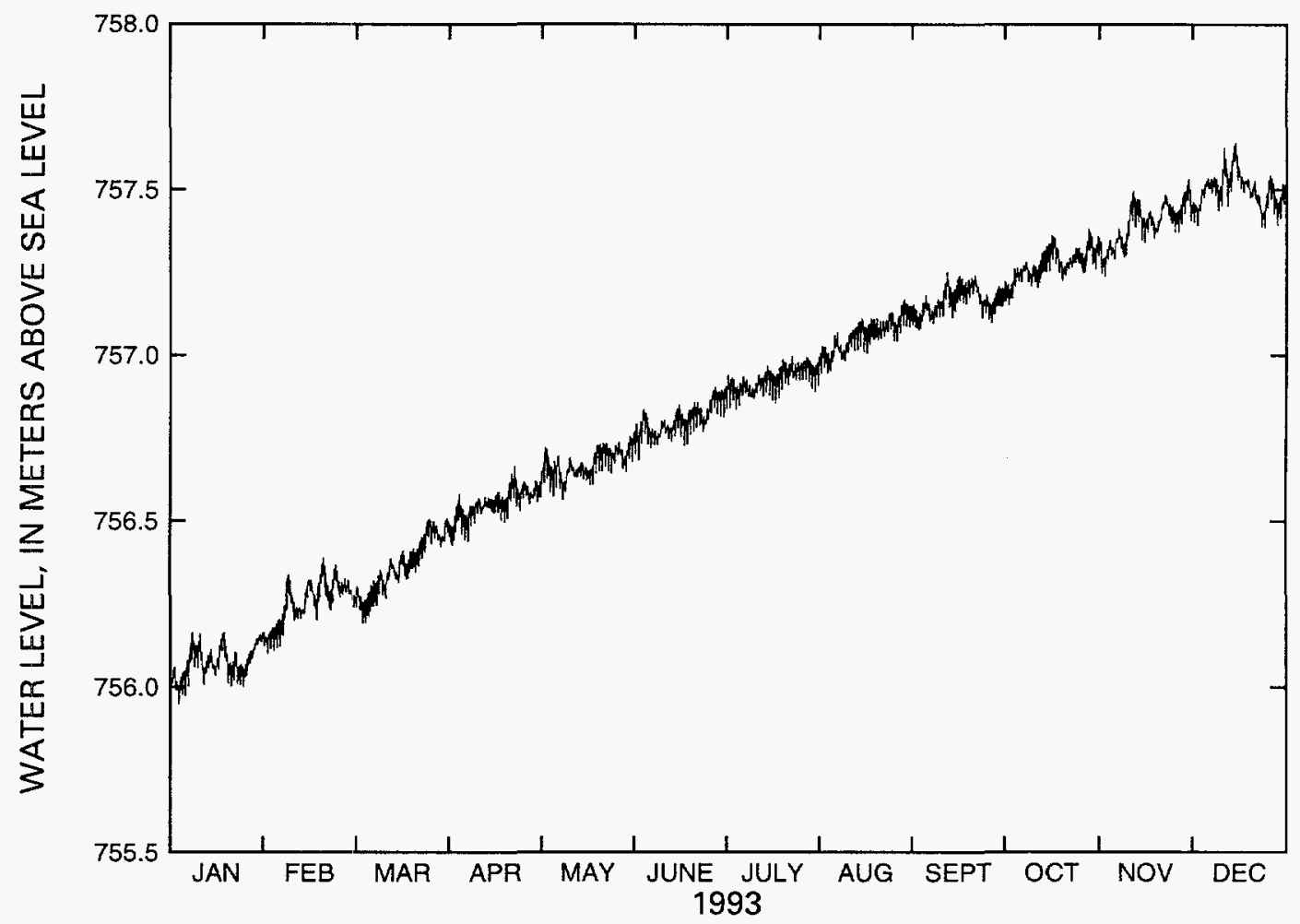

Figure 30. Water-level altitudes, 1993, for well USW H-3, lower interval.

Table 32. Mean monthly water-level altitudes, 1993, for well USW $\mathrm{H}-3$, lower interval

\begin{tabular}{lcc}
\hline Month & $\begin{array}{c}\text { Water-level altitude } \\
\text { (meters, above sea level) }\end{array}$ & $\begin{array}{c}\text { Number of missing } \\
\text { daily means }\end{array}$ \\
\hline January & 756.07 & 1 \\
February & 756.26 & 0 \\
March & 756.35 & 0 \\
April & 756.54 & 0 \\
May & 756.66 & 0 \\
June & 756.80 & 0 \\
July & 756.92 & 0 \\
August & 757.06 & 0 \\
September & 757.16 & 0 \\
October & 757.27 & 0 \\
November & 757.40 & 2 \\
December & 757.50 & 0 \\
\hline
\end{tabular}




\section{Well USW H-4}

Information about the history of well USW H-4 and about previous data from the well was obtained from various sources. These sources are: Whitfield and others (1984); Whitfield and others (1985); Robison (1984, 1986); Robison and others (1988); Erickson and Waddell (1985); and Fenix \& Scisson, Inc. $(1987 \mathrm{a}, 1987 \mathrm{c})$.

\section{Well specifications}

1. Location and identification:

Latitude and longitude: $36^{\circ} 50^{\prime} 32^{\prime \prime} \mathrm{N}$.; $116^{\circ} 26^{\prime} 54^{\prime \prime} \mathrm{W}$.

Nevada State Central Zone Coordinates (m): N 232,149; E 171,880.

U.S. Geological Survey Site ID: 365032116265401.

2. Drilling and casing information:

Well started: March 22, 1982.

Well completed: June 7, 1982.

Drilling method: Rotary, using rock bits and air-foam circulating medium; selected core obtained.

Bit diameter below water level: $375 \mathrm{~mm}$ to $564 \mathrm{~m} ; 222 \mathrm{~mm}$ from 564 to $1,219 \mathrm{~m}$.

Casing extending below water level: $253 \mathrm{~mm}$ diameter to $561 \mathrm{~m}$, perforated below the water level.

Total drilled depth: $1,219 \mathrm{~m}$.

3. Access to and description of interval for measuring water levels:

\section{Upper interval:}

48-mm inside-diameter open-ended tubing, extending from land surface to depth of $525 \mathrm{~m}$; upper interval of well near water table to top of inflatable packer within Prow Pass, Bullfrog, and Tram Members of Crater Flat Tuff, bedded tuff, and upper Lithic Ridge Tuff;

\section{Lower interval:}

62-mm inside-diameter tubing with inflatable packer on bottom end, extending from surface to $1,188 \mathrm{~m}$; lower interval of well within Lithic Ridge Tuff.

4. Information for calculating water-level altitude:

Reference point: Top of metal tag on well casing; altitude 1,248.74 m (surveyed by U.S. Geological Survey, 1984).

Measuring point: Top of access tubes, $0.597 \mathrm{~m}$, upper interval; $0.308 \mathrm{~m}$, lower interval.

Depth correction for borehole deviation from vertical: $0.064 \mathrm{~m}$, based on approximate depth to water of $518 \mathrm{~m}$.

\section{Transducer calibrations and comments}

\section{Upper interval:}

Three calibrations of one transducer were performed during 1993. In addition, calibrations on 12/11/92 and 3/30/94 were used to calculate water-level altitudes at the beginning and end of 1993. Results of the calibrations and measured water-level altitudes obtained during the calibrations are as follows: 


\begin{tabular}{ccccc}
\hline $\begin{array}{c}\text { Transducer } \\
\text { serial number }\end{array}$ & $\begin{array}{c}\text { Calibration } \\
\text { date }\end{array}$ & $\begin{array}{c}\text { Slope } \\
(\mathrm{m} / \mathrm{mV})\end{array}$ & $\begin{array}{c}\text { Coefficient of } \\
\text { determination } \\
\left(\mathbf{r}^{2}\right)\end{array}$ & $\begin{array}{c}\text { Water-Jevel } \\
\text { altitude } \\
(\mathrm{m})\end{array}$ \\
\hline 365013 & $12 / 11 / 92$ & 0.089 & 1.00 & 730.46 \\
365013 & $04 / 08 / 93$ & .090 & 1.00 & 730.38 \\
365013 & $07 / 29 / 93$ & .089 & 1.00 & 730.37 \\
365013 & $11 / 30 / 93$ & .090 & 1.00 & 730.46 \\
365013 & $03 / 30 / 94$ & .090 & 1.00 & 730.31 \\
\hline
\end{tabular}

Data from $1 / 5$ to $1 / 6 / 93$ were not valid due to a calibration of the lower interval. A spike on $7 / 29 / 93$, associated with a calibration of the upper interval, was removed, as was a spike on $8 / 22 / 93$ that was probably caused by electronic noise.

\section{Lower interval:}

Five calibrations of two transducers were performed during 1993. In addition, calibrations on $12 / 10 / 92$ and 4/26/94 were used to calculate water-level altitudes at the beginning of 1993 . Results of the calibrations and measured water-level altitudes obtained during the calibrations are as follows:

\begin{tabular}{ccccc}
\hline $\begin{array}{c}\text { Transducer } \\
\text { serial number }\end{array}$ & $\begin{array}{c}\text { Calibration } \\
\text { date }\end{array}$ & $\begin{array}{c}\text { Slope } \\
(\mathrm{m} / \mathrm{mV})\end{array}$ & $\begin{array}{c}\text { Coefficient of } \\
\text { determination } \\
\left(\mathbf{r}^{2}\right)\end{array}$ & $\begin{array}{c}\text { Water-level } \\
\text { altitude } \\
(\mathrm{m})\end{array}$ \\
\hline 473980 & $12 / 10 / 92$ & 11.23 & 1.00 & 730.49 \\
255367 & $01 / 05 / 93$ & 0.090 & 1.00 & 730.58 \\
255367 & $04 / 08 / 93$ & .088 & 1.00 & 730.51 \\
255367 & $07 / 29 / 93$ & .084 & 1.00 & 730.49 \\
567098 & $09 / 01 / 93$ & .088 & 1.00 & 730.45 \\
567098 & $12 / 28 / 93$ & .088 & 1.00 & 730.46 \\
567098 & $04 / 26 / 94$ & .088 & 1.00 & 730.57 \\
\hline
\end{tabular}

Transducer data from $1 / 1$ to $1 / 6 / 93$, and from $6 / 25$ to $9 / 3 / 93$, are invalid because of transducer failure. A spike on $9 / 17 / 93$, probably caused by electronic noise, was removed.

\section{Water-level altitudes}

Upper interval:

Water-level altitudes for well USW H-4, upper interval, ranged from 730.29 to $730.57 \mathrm{~m}$ above sea level in 1993 (fig. 31). The mean water-level altitude for 1993 was $730.53 \mathrm{~m}$ above sea level. This mean altitude is $0.04 \mathrm{~m}$ lower than the mean altitude of $730.57 \mathrm{~m}$ for 1992 (O'Brien and others, 1995). Mean monthly water-level altitudes are listed in table 33.

\section{Lower interval:}

Water-level altitudes for well USW H-4, lower interval, ranged from 730.37 to $730.72 \mathrm{~m}$ above sea level in 1993 (fig. 32). The mean water-level altitude for $1993 \mathrm{was} 730.41 \mathrm{~m}$ above sea level. This mean altitude is $0.16 \mathrm{~m}$ lower than the mean altitude of $730.58 \mathrm{~m}$ for 1992 (O'Brien and others, 1995). Mean monthly water-level altitudes are listed in table 34. 


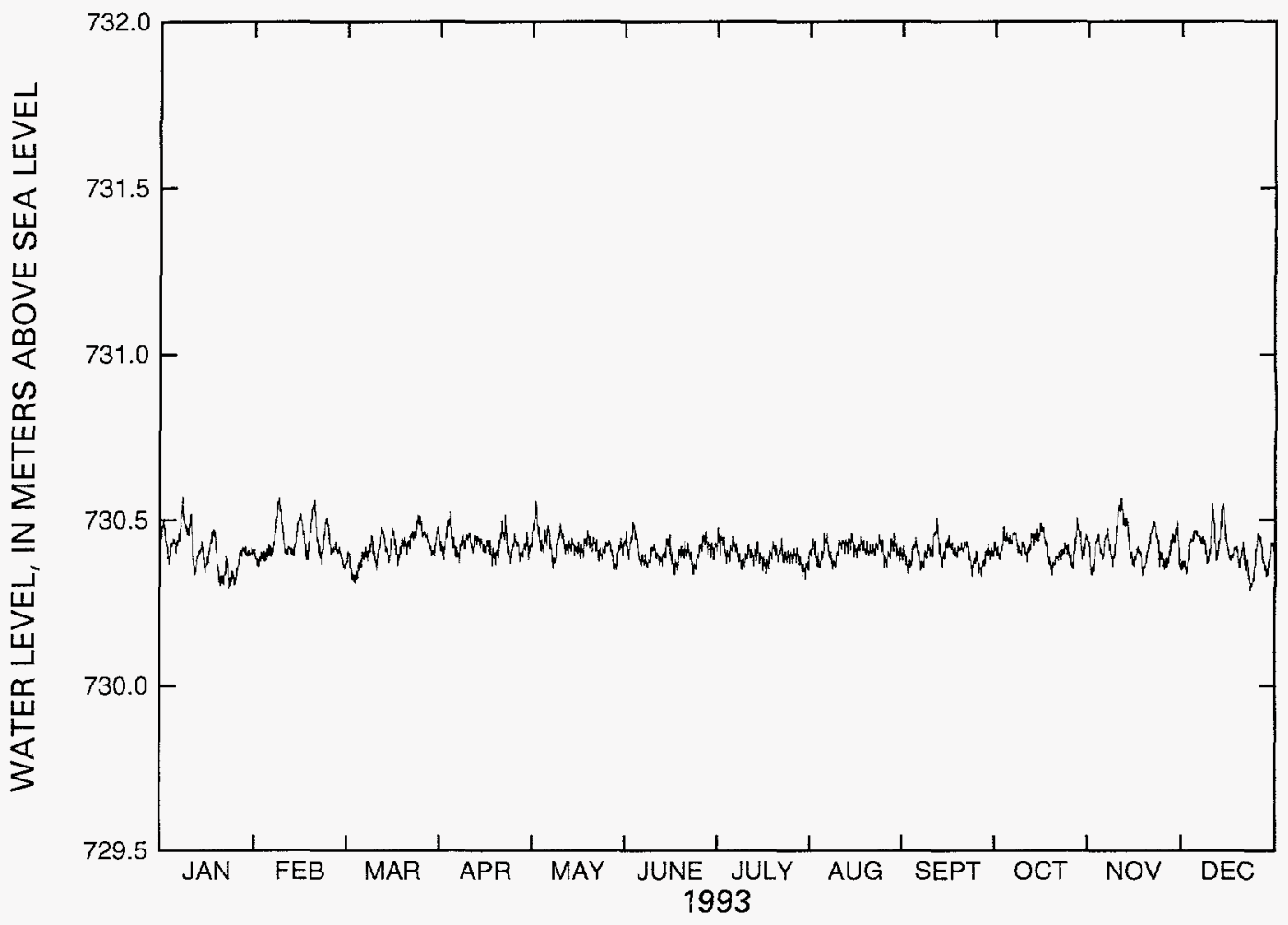

Figure 31. Water-level altitudes, 1993, for well USW H-4, upper interval.

Table 33. Mean monthly water-level altitudes, 1993, for well USW H-4, upper interval

\begin{tabular}{lcc}
\hline Month & $\begin{array}{c}\text { Water-level altitude } \\
\text { (meters, above sea level) }\end{array}$ & $\begin{array}{c}\text { Number of missing } \\
\text { daily means }\end{array}$ \\
\hline January & 730.40 & 2 \\
February & 730.44 & 0 \\
March & 730.41 & 0 \\
April & 730.43 & 0 \\
May & 730.42 & 0 \\
June & 730.40 & 0 \\
July & 730.40 & 0 \\
August & 730.41 & 0 \\
September & 730.40 & 0 \\
October & 730.42 & 0 \\
November & 730.42 & 0 \\
December & 730.41 & 0 \\
\hline
\end{tabular}




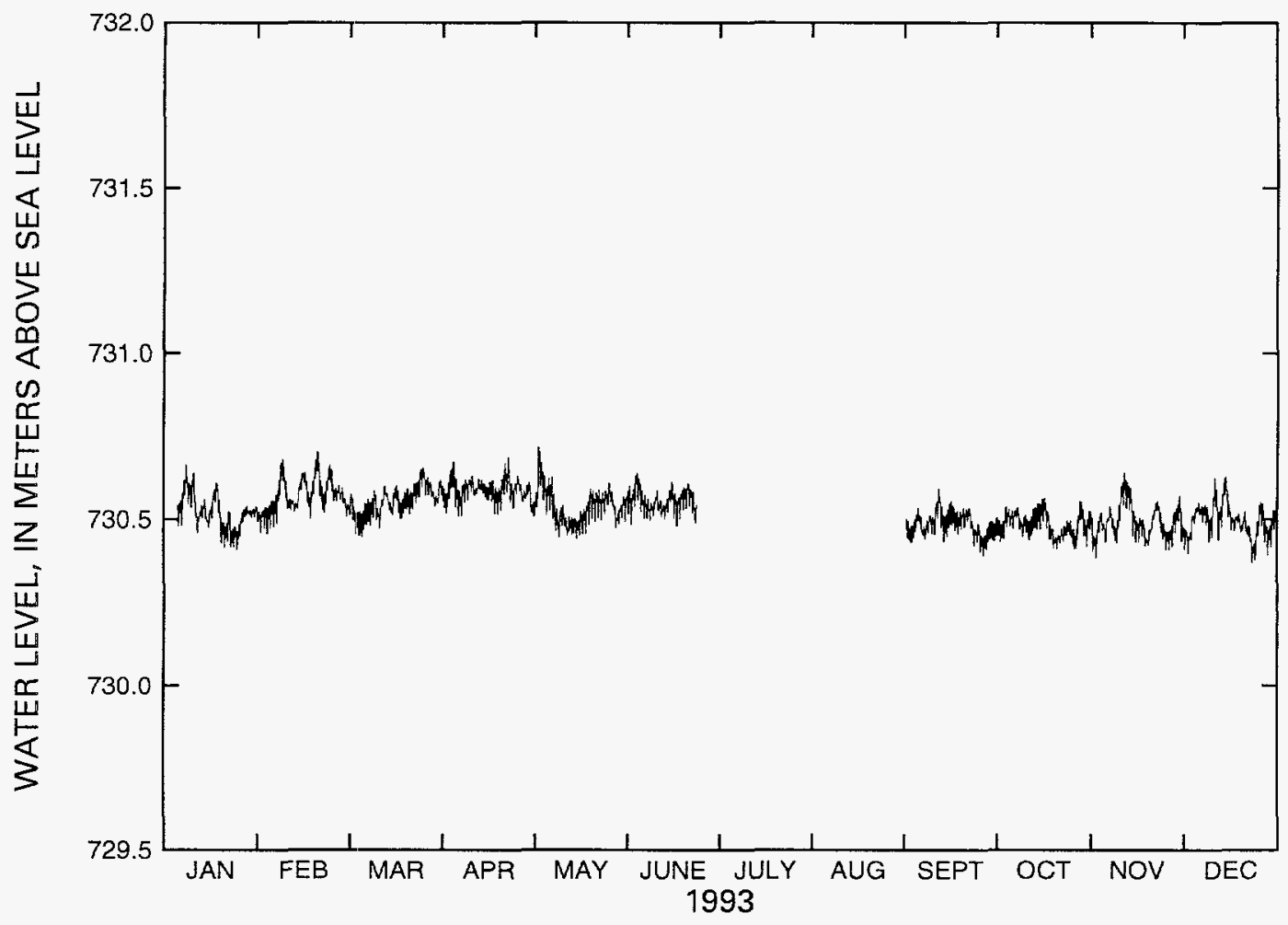

Figure 32. Water-level altitudes, 1993, for well USW H-4, lower interval.

Table 34. Mean monthly water-level altitudes, 1993, for well USW H-4, lower interval

[NA, not available]

\begin{tabular}{lcc}
\hline Month & $\begin{array}{c}\text { Water-level altitude } \\
\text { (meters, above sea level) }\end{array}$ & $\begin{array}{c}\text { Number of missing } \\
\text { daily means }\end{array}$ \\
\hline January & 730.52 & 6 \\
February & 730.57 & 0 \\
March & 730.55 & 0 \\
April & 730.59 & 0 \\
May & 730.53 & 0 \\
June & 730.55 & 6 \\
July & NA & 31 \\
August & NA & 31 \\
September & 730.48 & 2 \\
October & 730.48 & 0 \\
November & 730.49 & 0 \\
December & 730.49 & 0 \\
\hline
\end{tabular}




\section{Well USW H-5}

Information about the history of well USW H-5 and about previous data from the well was obtained from various sources. These sources are: Bentley and others (1983); Robison $(1984,1986)$; Robison and others (1988); and Fenix \& Scisson, Inc. (1987a, 1987c).

Well specifications

1. Location and identification:

Latitude and longitude: $36^{\circ} 51^{\prime 2} 22^{\prime \prime} \mathrm{N}$.; $116^{\circ} 27^{\prime} 55^{\prime \prime} \mathrm{W}$.

Nevada State Central Zone Coordinates (m): N 233,670; E 170,355.

U.S. Geological Survey Site ID: 365122116275502.

2. Drilling and casing information:

Well started: May 19, 1982.

Well completed: August 1, 1982.

Drilling method: Rotary, using rock bits and air-foam circulating medium; selected core obtained.

Bit diameter below water level: $375 \mathrm{~mm}$ to $792 \mathrm{~m} ; 222 \mathrm{~mm}$ from 792 to $1,219 \mathrm{~m}$.

Casing extending below water level: $255 \mathrm{~mm}$ diameter to $788 \mathrm{~m}$, perforated below the water level.

Total drilled depth: $1,219 \mathrm{~m}$.

3. Access to and description of interval for measuring water levels:

\section{Upper interval:}

48-mm inside-diameter open-ended tubing, extending from land surface to a depth of $709 \mathrm{~m}$; upper saturated interval of borehole within Bullfrog and Tram Members of Crater Flat Tuff, bedded tuff, and unnamed lava beneath the Tram Member (Carr, 1988, p. 37).

\section{Lower interval:}

62-mm inside-diameter tubing that has a 3.6-m-long inflatable packer on bottom end, extending from land surface to $846 \mathrm{~m}$; lower interval within the Tram Member of Crater Flat Tuff, and within an unnamed lava unit below the Tram (Carr, 1988, p. 37).

Note: The packer was reset at its present depth $(846 \mathrm{~m})$ on $3 / 25 / 93$, from its previous depth of 1,091 m (G.M. O'Brien, U.S. Geological Survey, written commun., 1993).

4. Information for calculating water-level altitude:

Reference point: Top of metal tag on well casing; altitude 1,478.94 m (surveyed by U.S. Geological Survey, 1984).

Measuring point: Top of access tubes, $0.329 \mathrm{~m}$, upper interval; $0.235 \mathrm{~m}$, lower interval.

Depth correction for borehole deviation from vertical: $0.079 \mathrm{~m}$, based on approximate depth to water of $703 \mathrm{~m}$.

\section{Transducer calibrations and comments}

\section{Upper interval:}

Six calibrations of one transducer were performed during 1993. In addition, calibrations on 9/21/92 and 1/10/94 were used to calculate water-level altitudes at the beginning and end of 1993 . 
Results of the calibrations and measured water-level altitudes obtained during the calibrations are as follows:

\begin{tabular}{ccccc}
\hline $\begin{array}{c}\text { Transducer } \\
\text { serial number }\end{array}$ & $\begin{array}{c}\text { Calibration } \\
\text { date }\end{array}$ & $\begin{array}{c}\text { Slope } \\
(\mathrm{m} / \mathrm{mV})\end{array}$ & $\begin{array}{c}\text { Coefficient of } \\
\text { determination } \\
\left(\mathbf{r}^{2}\right)\end{array}$ & $\begin{array}{c}\text { Water-level } \\
\text { altitude } \\
(\mathrm{m})\end{array}$ \\
\hline 506116 & $09 / 21 / 92$ & 0.089 & 1.00 & 775.63 \\
506116 & $01 / 20 / 93$ & .089 & 1.00 & 775.63 \\
506116 & $03 / 12 / 93$ & .089 & 1.00 & 775.57 \\
506116 & $04 / 05 / 93$ & .090 & 1.00 & 775.57 \\
506116 & $04 / 16 / 93$ & .090 & 1.00 & 775.55 \\
506116 & $07 / 15 / 93$ & .089 & 1.00 & 775.55 \\
506116 & $11 / 10 / 93$ & .090 & 1.00 & 775.59 \\
506116 & $01 / 10 / 94$ & .090 & 1.00 & 775.54 \\
\hline
\end{tabular}

No data are available on $1 / 20,3 / 12,4 / 5,4 / 16,7 / 15$, and $11 / 10 / 93$, due to transducer calibrations. No data are available on $3 / 5,4 / 14,4 / 15,5 / 21,5 / 22,7 / 4,7 / 12,8 / 11,9 / 3,9 / 27,11 / 22,12 / 7$, and 12/14/93, due to equipment problems. No data are available from $3 / 13$ to $4 / 4 / 93$, because of repairs to the lower interval of the well. Data from 12/18 through 12/31/93 are invalid because of transducer failure.

\section{Lower interval:}

Six calibrations of two transducers were performed during 1993. In addition, a calibration on 01/20/94 was used to calculate water-level altitudes at the end of 1993 . Results of the calibrations and measured water-level altitudes obtained during the calibrations are as follows:

\begin{tabular}{ccccc}
\hline $\begin{array}{c}\text { Transducer } \\
\text { serial number }\end{array}$ & $\begin{array}{c}\text { Calibration } \\
\text { date }\end{array}$ & $\begin{array}{c}\text { Slope } \\
(\mathrm{m} / \mathrm{mV})\end{array}$ & $\begin{array}{c}\text { Coefficient of } \\
\text { determination } \\
\left(\mathrm{r}^{2}\right)\end{array}$ & $\begin{array}{c}\text { Water-level } \\
\text { altitude } \\
(\mathrm{m})\end{array}$ \\
\hline 502725 & $04 / 15 / 93$ & 0.089 & 1.00 & 775.77 \\
502725 & $07 / 15 / 93$ & .089 & 1.00 & 775.80 \\
502725 & $09 / 27 / 93$ & .089 & 1.00 & 775.64 \\
567089 & $09 / 27 / 93$ & .089 & 1.00 & 775.64 \\
567089 & $12 / 14 / 93$ & .089 & 1.00 & 775.80 \\
567095 & $12 / 14 / 93$ & .089 & 1.00 & 775.80 \\
567095 & $01 / 20 / 94$ & .089 & 1.00 & 775.66 \\
\hline
\end{tabular}

No data were collected from $1 / 1$ to $4 / 20 / 93$, because the small-diameter packer and the transducer were stuck in lower-interval access tubing. After the equipment was pulled free, the packer used to isolate the lower interval was raised from 1,091 to $846 \mathrm{~m}$ below land surface on $04 / 15 / 93$. This reconfiguration allows for monitoring of a larger interval with more water-bearing fractures than the previous configuration. Data are missing on $5 / 21$ and $5 / 22 / 93$, due to changes to equipment programs. A small spike on 7/12/93, at 0700 hours, is associated with an earthquake near Hokkaido, Japan. 


\section{Water-level altitudes}

\section{Upper interval:}

Water-level altitudes for well USW H-5, upper interval, ranged from 775.45 to $775.89 \mathrm{~m}$ above sea level in 1993 (fig. 33). The mean water-level altitude for 1993 was $775.59 \mathrm{~m}$ above sea level. This mean altitude is $0.06 \mathrm{~m}$ lower than the mean altitude of $775.65 \mathrm{~m}$ for 1992 (O'Brien and others, 1995). Mean monthly water-level altitudes are listed in table 35 .

\section{Lower interval:}

Water-level altitudes recorded by hourly monitoring for well USW H-5, lower interval, ranged from 775.51 to $775.88 \mathrm{~m}$ above sea level in 1993 (fig. 34). The mean water-level altitude for 1993 was $775.72 \mathrm{~m}$ above sea level. This mean altitude is $0.17 \mathrm{~m}$ higher than the mean altitude of $775.55 \mathrm{~m}$ for 1992 (O'Brien and others, 1995). Mean monthly water-level altitudes are listed in table 36. A manual water-level measurement of $775.80 \mathrm{~m}$ above sea level was obtained using Chain \#2 on $3 / 25 / 93$.

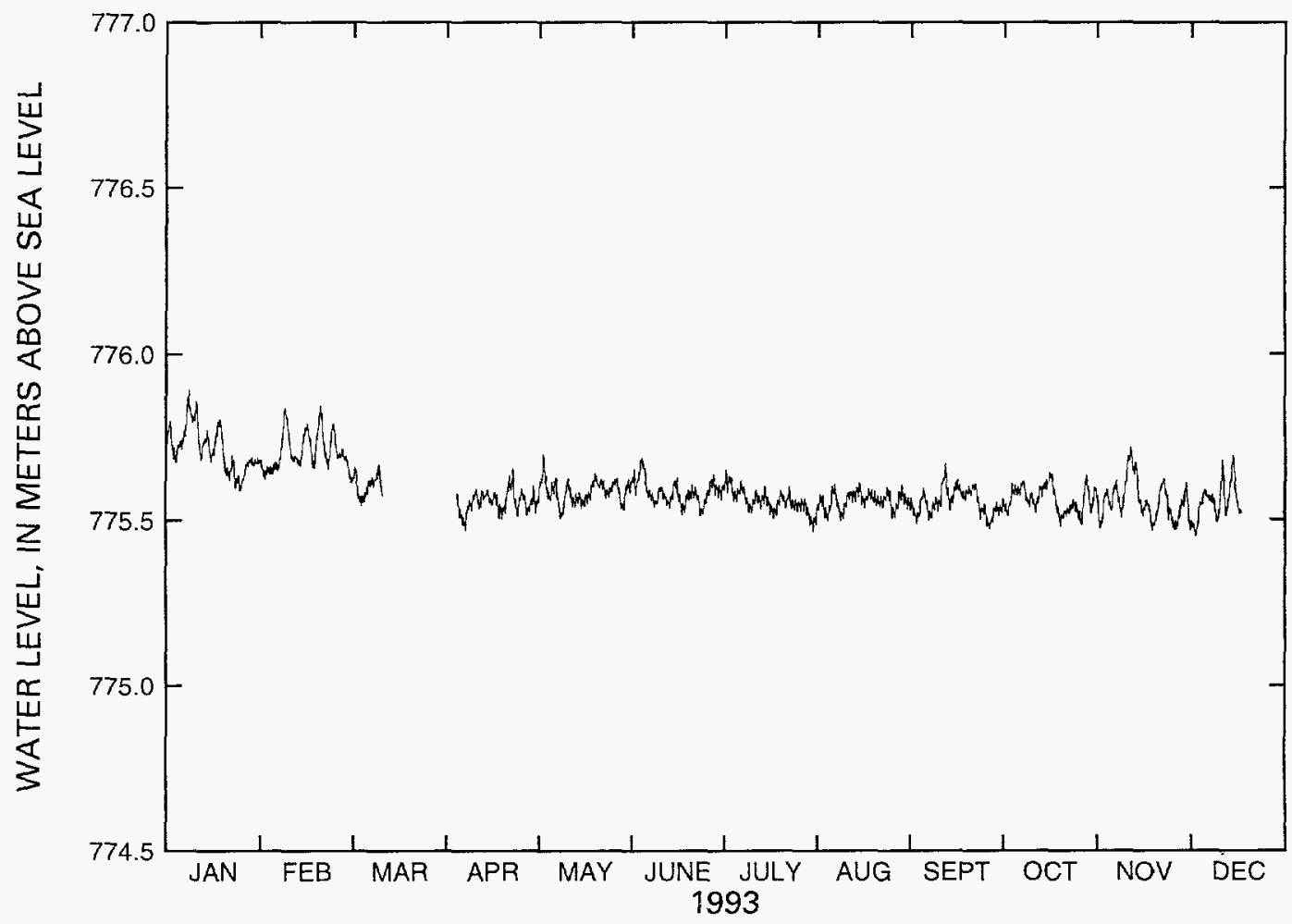

Figure 33. Water-level altitudes, 1993, for well USW H-5, upper interval. 
Table 35. Mean monthly water-level altitudes, 1993, for well USW H-5, upper interval

\begin{tabular}{lcc}
\hline Month & $\begin{array}{c}\text { Water-level altitude } \\
\text { (meters, above sea level) }\end{array}$ & $\begin{array}{c}\text { Number of missing } \\
\text { daily means }\end{array}$ \\
\hline January & 775.72 & 1 \\
February & 775.71 & 0 \\
March & 775.61 & 21 \\
April & 775.55 & 8 \\
May & 775.58 & 2 \\
June & 775.58 & 1 \\
July & 775.55 & 3 \\
August & 775.55 & 1 \\
September & 775.56 & 2 \\
October & 775.56 & 0 \\
November & 775.56 & 2 \\
December & 775.55 & 16 \\
\hline
\end{tabular}

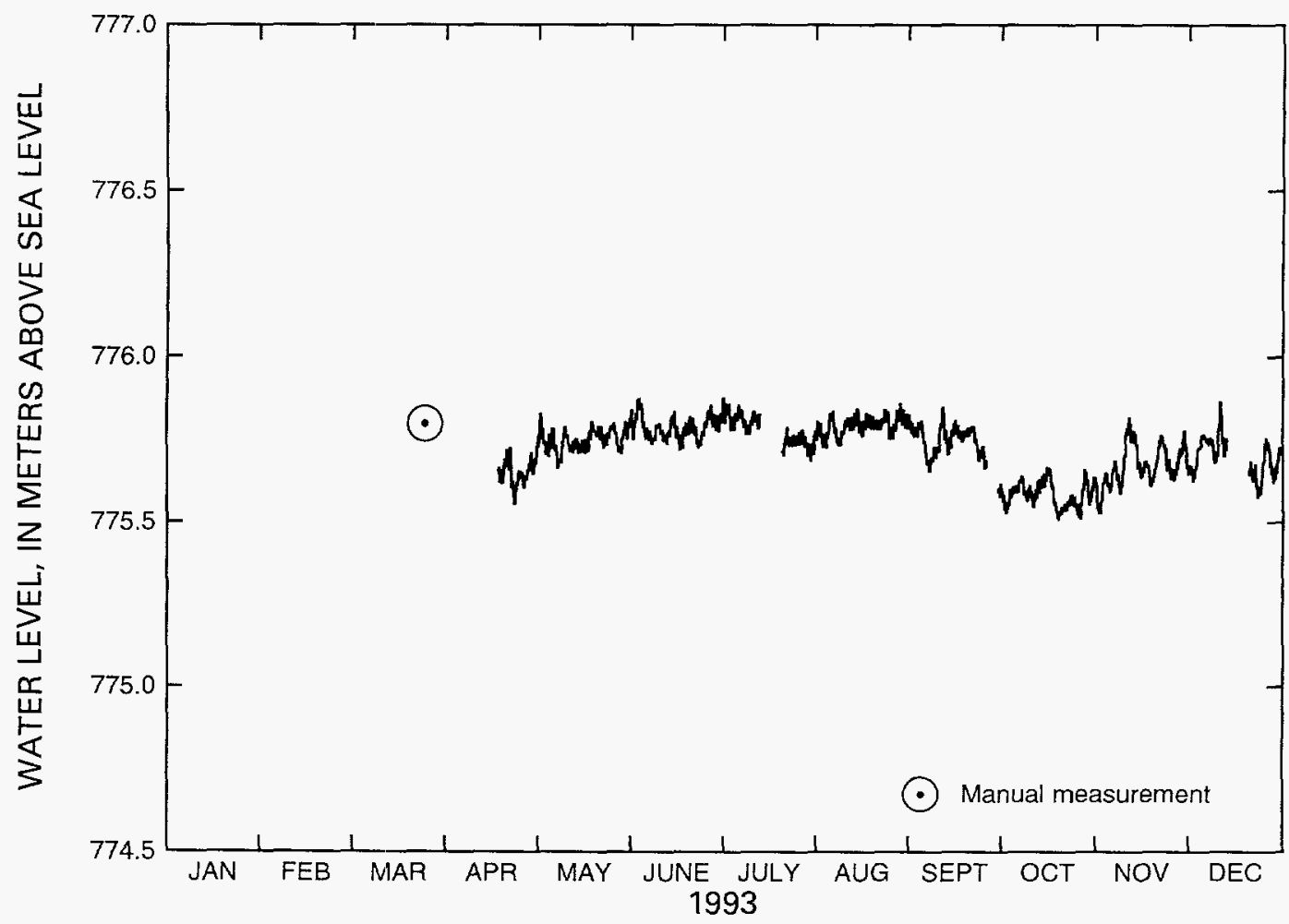

Figure 34. Water-level altitudes, 1993 , for well USW H-5, lower interval. 
Table 36. Mean monthly water-level altitudes, 1993, for well USW H-5, lower interval

[NA, not available]

\begin{tabular}{lcc}
\hline Month & $\begin{array}{c}\text { Water-level altitude } \\
\text { (meters, above sea level) }\end{array}$ & $\begin{array}{c}\text { Number of missing } \\
\text { daily means }\end{array}$ \\
\hline January & NA & 31 \\
February & NA & 28 \\
March & NA & 31 \\
April & 775.64 & 20 \\
May & 775.74 & 2 \\
June & 775.78 & 0 \\
July & 775.79 & 8 \\
August & 775.79 & 1 \\
September & 775.75 & 4 \\
October & 775.58 & 0 \\
November & 775.67 & 0 \\
December & 775.70 & 8 \\
\hline
\end{tabular}

\section{Well USW H-6}

Information about the history of well USW H-6 and about previous data from the well was obtained from various sources. These sources are: Craig and others (1983); Robison $(1984,1986)$; Robison and others (1988); and Fenix \& Scisson, Inc. (1987a, 1987c).

\section{Well specifications}

1. Location and identification:

Latitude and longitude: $36^{\circ} 50^{\prime} 49^{\prime \prime} \mathrm{N} . ; 116^{\circ} 28^{\prime} 55^{\prime \prime} \mathrm{W}$.

Nevada State Central Zone Coordinates (m): N 232,654; E 168,882.

U.S. Geological Survey Site ID: 365049116285501.

2. Drilling and casing information:

Well started: August 7, 1982.

Well completed: October 28, 1982.

Drilling method: Rotary, using rock bits and air-foam circulating medium; selected core obtained.

Bit diameter below water level: $375 \mathrm{~mm}$ to $583 \mathrm{~m} ; 222 \mathrm{~mm}$ from 583 to $1,216 \mathrm{~m} ; 156 \mathrm{~mm}$ from 1,216 to $1,220 \mathrm{~m}$.

Casing extending below water level: $250-\mathrm{mm}$ diameter to $581 \mathrm{~m}$, perforated below the water level.

Total drilled depth: $1,220 \mathrm{~m}$.

3. Access to and description of interval for measuring water levels:

\section{Upper interval:}

48-mm inside-diameter open-ended tubing, extending from land surface to $533 \mathrm{~m}$; saturated upper interval within Prow Pass, Bullfrog, and Tram Members of Crater Flat Tuff, and bedded tuff. 


\section{Lower interval:}

62-mm inside-diameter tubing with inflatable packer on bottom end, extending from land surface to $752 \mathrm{~m}$; lower interval within Tram Member of Crater Flat Tuff, bedded tuff, unnamed lava between Tram Member and Lithic Ridge Tuff (Carr, 1988 p. 37) and Lithic Ridge Tuff.

4. Information for calculating water-level altitude:

Reference point: Top of metal tag on well casing; altitude 1,302.06 m (surveyed by U.S. Geological Survey, 1984).

Measuring point: Top of access tubes, $0.207 \mathrm{~m}$, upper interval; $0.235 \mathrm{~m}$, lower interval.

Depth correction for borehole deviation from vertical: $0.052 \mathrm{~m}$, based on approximate depth to water of $526 \mathrm{~m}$.

\section{Transducer calibrations and comments}

\section{Upper interval:}

Four calibrations of one transducer were performed during 1993. In addition, calibrations on 11/04/92 and 2/11/94 were used to calculate water-level altitudes at the beginning and end of 1993. Results of the calibrations and measured water-level altitudes obtained during the calibrations are as follows:

\begin{tabular}{ccccc}
\hline $\begin{array}{c}\text { Transducer } \\
\text { serial number }\end{array}$ & $\begin{array}{c}\text { Calibration } \\
\text { date }\end{array}$ & $\begin{array}{c}\text { Slope } \\
(\mathbf{m} / \mathbf{m V})\end{array}$ & $\begin{array}{c}\text { Coefficient of } \\
\text { determination } \\
\left(\mathbf{r}^{2}\right)\end{array}$ & $\begin{array}{c}\text { Water-level } \\
\text { altitude } \\
(\mathbf{m})\end{array}$ \\
\hline 255365 & $11 / 04 / 92$ & 0.088 & 1.00 & 776.01 \\
255365 & $03 / 02 / 93$ & .088 & 1.00 & 776.02 \\
255365 & $06 / 23 / 93$ & .089 & 1.00 & 776.08 \\
255365 & $06 / 25 / 93$ & .088 & 1.00 & 776.02 \\
255365 & $10 / 25 / 93$ & .088 & 1.00 & 776.05 \\
255365 & $02 / 11 / 94$ & .088 & 1.00 & 776.07 \\
\hline
\end{tabular}

Data are missing for $6 / 23 / 93$ due to a calibration. Transducer data were erratic and considered unreliable from $7 / 7$ to $7 / 11 / 93$. A spike on $12 / 21 / 93$, probably caused by electronic noise, was considered invalid.

\section{Lower interval:}

Eight calibrations of four transducers were performed during 1993. In addition, calibrations on 11/04/92 and 4/8/94 were used to calculate water-level altitudes at the beginning and end of 1993. Results of the calibrations and measured water-level altitudes obtained during the calibrations are as follows: 


\begin{tabular}{ccccc}
\hline $\begin{array}{c}\text { Transducer } \\
\text { serial number }\end{array}$ & $\begin{array}{c}\text { Calibration } \\
\text { date }\end{array}$ & $\begin{array}{c}\text { Slope } \\
(\mathbf{m} / \mathbf{m V})\end{array}$ & $\begin{array}{c}\text { Coefficient of } \\
\text { determination } \\
\left(\mathbf{r}^{2}\right)\end{array}$ & $\begin{array}{c}\text { Water-level } \\
\text { altitude } \\
(\mathbf{m})\end{array}$ \\
\hline 506114 & $11 / 04 / 92$ & 0.089 & 1.00 & 775.97 \\
506114 & $03 / 02 / 93$ & .089 & 1.00 & 775.97 \\
506114 & $06 / 23 / 93$ & .089 & 1.00 & 775.99 \\
465820 & $07 / 21 / 93$ & .089 & 1.00 & 776.01 \\
465820 & $08 / 03 / 93$ & .090 & 1.00 & 776.00 \\
567093 & $08 / 04 / 93$ & .090 & 1.00 & 775.98 \\
567093 & $11 / 29 / 93$ & .090 & 1.00 & 776.10 \\
567093 & $12 / 21 / 93$ & .090 & 1.00 & 776.00 \\
525612 & $12 / 21 / 93$ & .356 & 1.00 & 776.00 \\
525612 & $04 / 08 / 94$ & .358 & 1.00 & 776.05 \\
\hline
\end{tabular}

Data are missing on $6 / 23 / 93$, due to a calibration. Data are missing $6 / 29,7 / 15$ to $7 / 21$, and $7 / 27$ to $8 / 4 / 93$, due to transducer failure. Data from $10 / 12$ to $12 / 22 / 93$ were considered unreliable due to excessive transducer drift. A small spike on $7 / 12 / 93$ at 0700 hrs was associated with an earthquake near Hokkaido, Japan.

\section{Water-level altitudes}

\section{Upper interval:}

Water-level altitudes for well USW H-6, upper interval, ranged from 775.94 to $776.23 \mathrm{~m}$ above sea level in 1993 (fig. 35). The mean water-level altitude for 1993 was $776.07 \mathrm{~m}$ above sea level. This mean altitude is $0.05 \mathrm{~m}$ higher than the mean altitude of $776.02 \mathrm{~m}$ for 1992 (O'Brien and others, 1995). Mean monthly water-level altitudes are listed in table 37.

\section{Lower interval:}

Water-level altitudes for well USW H-6, lower interval, ranged from 775.82 to $776.18 \mathrm{~m}$ above sea level in 1993 (fig. 36). The mean water-level altitude for 1993 was $775.97 \mathrm{~m}$ above sea level. This mean altitude is $0.04 \mathrm{~m}$ higher than the mean altitude of $775.93 \mathrm{~m}$ for 1992 (O'Brien and others, 1995). Mean monthly water-level altitudes are listed in table 38. 


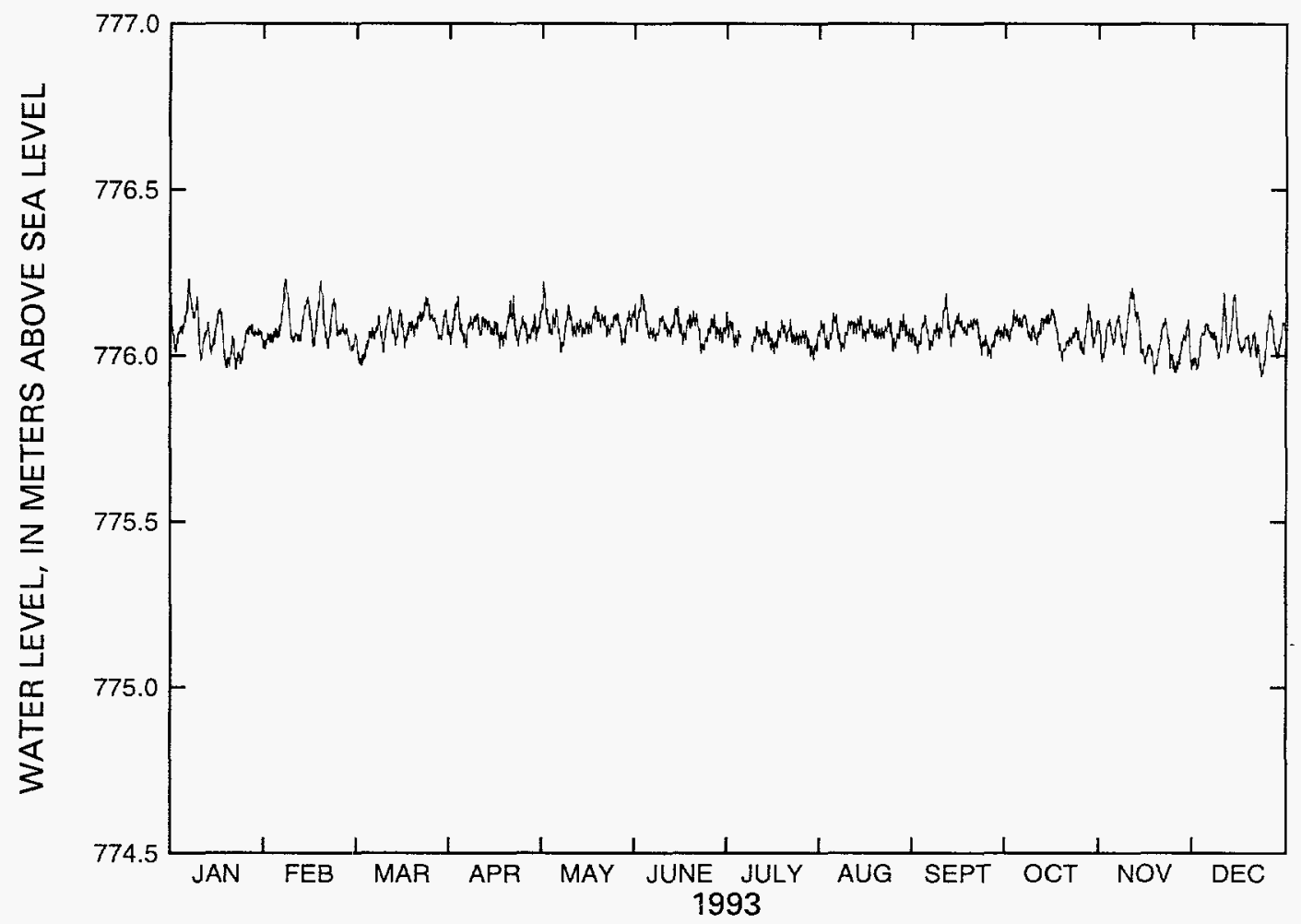

Figure 35. Water-level altitudes, 1993, for well USW H-6, upper interval.

Table 37. Mean monthly water-level altitudes, 1993, for well USW $H-6$, upper interval

\begin{tabular}{lcc}
\hline Month & $\begin{array}{c}\text { Water-level altitude } \\
\text { (meters, above sea level) }\end{array}$ & $\begin{array}{c}\text { Number of missing } \\
\text { daily means }\end{array}$ \\
\hline January & 776.07 & 0 \\
February & 776.09 & 0 \\
March & 776.07 & 0 \\
April & 776.09 & 0 \\
May & 776.09 & 0 \\
June & 776.09 & 1 \\
July & 776.06 & 5 \\
August & 776.07 & 2 \\
September & 776.07 & 0 \\
October & 776.07 & 0 \\
November & 776.05 & 0 \\
December & 776.05 & 1 \\
\hline
\end{tabular}




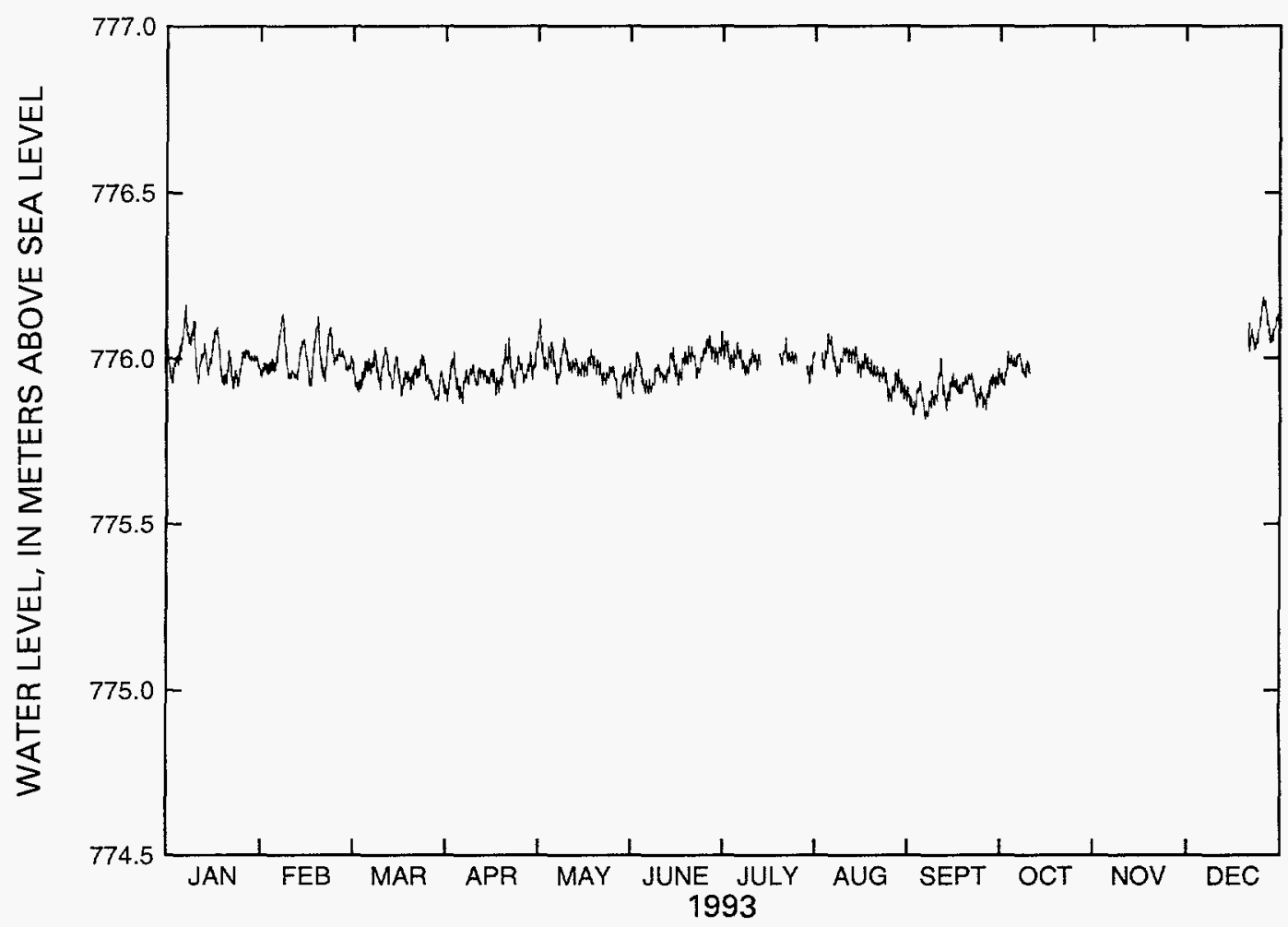

Figure 36. Water-level altitudes, 1993, for well USW H-6, lower interval.

Table 38. Mean monthly water-level altitudes, 1993, for well USW H-6, lower interval

[NA, not available]

\begin{tabular}{lcc}
\hline Month & $\begin{array}{c}\text { Water-level altitude } \\
\text { (meters, above sea level) }\end{array}$ & $\begin{array}{c}\text { Number of missing } \\
\text { daily means }\end{array}$ \\
\hline January & 776.00 & 0 \\
February & 776.00 & 0 \\
March & 775.95 & 0 \\
April & 775.95 & 0 \\
May & 775.98 & 0 \\
June & 775.97 & 2 \\
July & 776.00 & 11 \\
August & 775.97 & 3 \\
September & 775.90 & 0 \\
October & 775.97 & 20 \\
November & NA & 31 \\
December & 776.10 & 22 \\
\hline
\end{tabular}




\section{REFERENCES CITED}

Bentley, C.B., Robison, J.H., and Spengler, R.W., 1983, Geohydrologic data for test well USW H-5, Yucca Mountain area, Nye County, Nevada: U.S. Geological Survey Open-File Report 83-853, 34 p. (NNA.870519.0098)

Blee, J.W.H., Herlong, H.E., Kauffman, C.D., Jr., Hardee, J.H., Field, M.L., and Middleburg, R.F., Jr., 1986, GOES datacollection system instrumentation, installation, and maintenance manual: U.S. Geological Survey Open-File Report 86-479, [variously paged]. (NNA.940520.0054)

Boucher, M.S., 1994, Precision and accuracy of manual water-level measurements taken in the Yucca Mountain area, Nye County, Nevada, 1988-90: U.S. Geological Survey Water-Resources Investigations Report 93-4025, 18 p. (NNA.930323.0149)

Boucher, M.S., 1994, Water levels in wells J-11 and J-12, 1989-91, Yucca Mountain area, Nevada: U.S. Geological Survey Open-File Report 94-303, 9 p.

Byers, F.M., Jr., Carr, W.J., Orkild, P.P., Quinlivan, W.D., and Sargent, K.A., 1976, Volcanic suites and related cauldrons of Timber Mountain-Oasis Valley caldera complex, southern Nevada: U.S. Geological Survey Professional Paper 919, 70 p. (NNA.870406.0239)

Carr, W.J., Byers, F.M., Jr., and Orkild, P.P., 1986, Stratigraphic and volcano-tectonic relations of Crater Flat Tuff and some older volcanic units, Nye County, Nevada: U.S. Geological Survey Professional Paper 1323, 28 p. (HQS.880517.1115)

Carr, W.J., 1988, Volcano-tectonic setting of Yucca Mountain and Crater Flat, southwestern Nevada, in Carr, M.D., and Yount, J.C., eds., Geologic and hydrologic investigations of a potential nuclear waste disposal site at Yucca Mountain, southern Nevada: U.S. Geological Survey Bulletin 1790, p. 35-49. (NNA.891114.0346)

Craig, R.W., and Johnson, K.A., 1984, Geohydrologic data for test well UE-25p \#1, Yucca Mountain area, Nye County, Nevada: U.S. Geological Survey Open-File Report 84-450, 63 p. (NNA.870406.0256)

Craig, R.W., Reed, R.L., and Spengler, R.W., 1983, Geohydrologic data for test well USW H-6, Yucca Mountain area, Nye County, Nevada: U.S. Geological Survey Open-File Report 83-856, 35 p. (NNA.870406.0058)

Craig, R.W., and Robison, J.H., 1984, Geohydrology of test well UE-25p \#1, Yucca Mountain area, Nye County, Nevada: U.S. Geological Survey Water-Resources Investigations Report 84-4248, 57 p. (HQS.880517.1133)

Erickson, J.R., and Waddell, R.K., 1985, Identification and characterization of hydrologic properties of fractured tuff using hydraulic and tracer tests--Test well USW H-4, Yucca Mountain, Nye County, Nevada: U.S. Geological Survey Water-Resources Investigations Report 85-4066, 30 p. (NNA.870407.0184)

Fenix \& Scisson, Inc., 1986a, NNWSI hole histories-UE-25 WT \#3, UE-25 WT \#4, UE-25 WT \#5, UE-25 WT \#6, UE-25 WT \#12, UE-25 WT \#13, UE-25 WT \#14, UE-25 WT \#15, UE-25 WT \#16, UE-25 WT \#17, UE-25 WT \#18, USW WT-1, USW WT-2, USW WT-7, USW WT-10, USW WT-11: U.S. Department of Energy DOE/NV/10322-10, 111 p. (NNA.870317.0155)

1986b, NNWSI hole history-UE-25b \#1: U.S. Department of Energy DOE/NV/10322-13, 37 p. (HQS.880517.1200) 1986c, NNWSI hole history-UE-25p \#1: U.S. Department of Energy DOE/NV/10322-16, 39 p. (NNA.900326.0029) 1986d, NNWSI hole histories-UE-25c \#1, UE-25c \#2, UE-25c \#3: U.S. Department of Energy, DOE/NV/10322-14, 60 p. (HQS.880517.1201)

1987a, NNWSI hole histories-USW H-1, USW H-3, USW H-4, USW H-5, USW H-6: U.S. Department of Energy DOE/NV/10322-18, 99 p. (NNA.900330.0184)

1987b, NNWSI hole histories-USW G-1, USW G-2, USW G-3, USW G-4, USW GA-1, USW GU-3: U.S. Department of Energy DOE/NV/10322-19, 187 p. (HQS.880517.1194)

1987c, NNWSI drilling and mining summary: U.S. Department of Energy DOE/NV/10322-24, 45 p.

(NNA.890922.0283)

Garber, M.S., and Koopman, F.C., 1968, Methods of measuring water levels in deep wells: U.S. Geological Survey

Techniques of Water-Resources Investigations, book 8, chap. A-1, 23 p. (NNA.900104.0472)

Gemmell, J.M., 1990, Water levels in periodically measured wells in the Yucca Mountain area, Nevada, 1988: U.S. Geological Survey Open-File Report 90-113, 47 p. (NNA.900221.0001)

Lahoud, R.G., Lobmeyer, D.H., and Whitfield, M.S., Jr., 1984, Geohydrology of volcanic tuff penetrated by test well UE-25b \#1, Yucca Mountain, Nye County, Nevada: U.S. Geological Survey Water-Resources Investigations Report 84-4253, 44 p. (NNA.870519.0107)

Lobmeyer, D.H., Luckey, R.R., O'Brien, G.M., and Burkhardt, D.J., 1995, Water levels in continuously monitored wells in the Yucca Mountain area, Nevada, 1989: U.S. Geological Survey Open-File Report 93-098, 173 p. (NNA.930917.0086) 
Lobmeyer, D.H., Whitfield, M.S., Jr., Lahoud, R.G., and Bruckheimer, Laura, 1983, Geohydrologic data for test well UE-25b \#1, Nevada Test Site, Nye County, Nevada: U.S. Geological Survey Open-File Report 83-855, 48 p. (NNA.870406.0060)

Luckey, R.R., Lobmeyer, D.H., and Burkhardt, Douglas, 1993, Water levels in continuously monitored wells in the Yucca Mountain area, Nevada, 1985-88: U.S. Geological Survey Open-File Report 91-493, 252 p. (NNA.930112.0131)

Muller, D.C., and Kibler, J.E., 1985, Preliminary analysis of geophysical logs from WT series drill holes, Yucca Mountain, Nye County, Nevada: U.S. Geological Survey Open-File Report 86-46, 29 p. (NNA.940520.0056)

Nelson, P.H., Muller, D.C., Schimschal, Ulrich, and Kibler, J.E., 1991, Geophysical logs and core measurements from forty boreholes at Yucca Mountain, Nevada: U.S. Geological Survey Geophysical Investigations Map GP-1001, 64 p., 40 pls. (NNA.920211.0022)

Nelson, P.H., and Schimschal, Ulrich, 1993, Assessment of geophysical logs from borehole USW G-2, Yucca Mountain, Nevada: U.S. Geological Survey Open-File Report 92-572, 34 p. (NNA.921211.0173)

O’Brien, G.M., 1991, Water levels in periodically measured wells in the Yucca Mountain area, Nevada, 1989: U.S. Geological Survey Open-File Report 91-178, 51 p. (NNA.910708.0041)

1992, Earthquake-induced water-level fluctuations at Yucca Mountain, Nevada, April, 1992: U.S. Geological Survey Open-File Report 92-137, 10 p. (NNA.920626.0001)

1993, Earthquake-induced water-level fluctuations at Yucca Mountain, Nevada, June, 1992: U.S. Geological Survey Open-File Report 93-73, 12 p. (NNA.930326.0022)

O'Brien, G.M., Tucci, Patrick, and Burkhardt, D.J., 1995, Water levels in the Yucca Mountain area, Nevada, 1992: U.S. Geological Survey Open-File Report $94-311,74$ p. (NNA.940627.0003)

Robison, J.H., 1984, Ground-water level data and preliminary potentiometric surface maps, Yucca Mountain and vicinity, Nye County, Nevada: U.S. Geological Survey Water-Resources Investigations Report 84-4197, 8 p. (NNA.870519.0096) 1986, Letter from J.H. Robison (U.S. Geological Survey, Lakewood, Colorado) to D.L. Vieth (U.S. Department of Energy-Nevada Operations Office, Las Vegas, Nevada), September 17, 1986, regarding revisions of Yucca Mountain water levels reported in Robison, 1984. (HQS.880517.1935)

Robison, J.H., Stephens, D.M., Luckey, R.R., and Baldwin, D.A., 1988, Water levels in periodically measured wells in the Yucca Mountain area, Nevada, 1981-87: U.S. Geological Survey Open-File Report 88-468, 132 p. (NNA.890306.0113)

Rush, F.E., Thordarson, William, and Bruckheimer, Laura, 1983, Geohydrologic and drill-hole data for test well USW H-1, adjacent to Nevada Test Site, Nye County, Nevada: U.S. Geological Survey Open-File Report 83-141, 38 p. (NNA.870519.0103)

Rush, F.E., Thordarson, William, and Pyles, D.G., 1984, Geohydrology of test well USW H-1, Yucca Mountain, Nye County, Nevada: U.S. Geological Survey Water-Resources Investigations Report 84-4032, 56 p. (NNA.870518.0067)

Sass, J.H., and Lachenbruch, A.H., 1982, Preliminary interpretation of thermal data from the Nevada Test Site: U.S. Geological Survey Open-File Report 82-973, 30 p. (HQS.880517.1427)

Thordarson, William, 1983, Geohydrologic data and test results from well J-13, Nevada Test Site, Nye County, Nevada: U.S. Geological Survey Water-Resources Investigations Report 83-4171, 57 p. (NNA.870518.0071)

Thordarson, William, and Howells, Lewis, 1987, Hydraulic tests and chemical quality of water at well USW VH-1, Crater Flat, Nye County, Nevada: U.S. Geological Survey Water-Resources Investigations Report 86-4359, 20 p. (NNA.890922.0289)

Thordarson, William, Rush, F.E., Spengler, R.W., and Waddell, S.J., 1984, Geohydrologic and drill-hole data for test well USW H-3, Yucca Mountain, Nye County, Nevada: U.S. Geological Survey Open-File Report 84-149, 54 p. (NNA.870406.0056)

Thordarson, William, Rush, F.E., and Waddell, S.J., 1984, Geohydrology of test well USW H-3, Yucca Mountain, Nye County, Nevada: U.S. Geological Survey Water-Resources Investigations Report 84-4272, 38 p. (HQS.880517.1852)

Tucci, Patrick, O'Brien, G.M., and Burkhardt, D.J., 1996, Water levels in the Yucca Mountain area, Nevada, 1990-91: U.S. Geological Survey Open-File Report 94-111, 107 p. (NNA.940523.0065)

U.S. Department of Energy, 1988, Site characterization plan, Yucca Mountain site, Nevada research and development area, Nevada: U.S. Department of Energy Report DOE RW/0199, 8 v., [variously paged]. (HQS.881201.0002)

Waddell, R.K., 1982, Two-dimensional, steady-state model of ground-water flow, Nevada Test Site and vicinity, NevadaCalifornia: U.S. Geological Survey Water-Resources Investigations Report 82-4085, 77 p. (NNA.870518.0055)

Whitfield, M.S., Jr., Eshom, E.P., Thordarson, William, and Schaefer, D.H., 1985, Geohydrology of rocks penetrated by test well USW H-4, Yucca Mountain, Nye County, Nevada: U.S. Geological Survey Water-Resources Investigations Report $85-4030,33$ p. (HQS.880517.1870) 
Whitfield, M.S., Jr., Thordarson, William, and Eshom, E.P., 1984, Geohydrologic and drill-hole data for test well USW H-4, Yucca Mountain, Nye County, Nevada: U.S. Geological Survey Open-File Report 84-449, 39 p. (NNA.870407.0317) Winograd, I.J., and Thordarson, Williarn, 1975, Hydrogeologic and hydrochemical framework, south-central Great Basin, Nevada-California, with special reference to the Nevada Test Site: U.S. Geological Survey Professional Paper 712-C, 126 p. (HQS.880517.2908)

Young, R.A., 1972, Water supply for the Nuclear Rocket Development Station at the U.S. Atomic Energy Commission's Nevada Test Site: U.S. Geologicall Survey Water-Supply Paper 1938, 19 p. (NNA.870519.0070)

NOTE: Parenthesized numbers following each cited reference are for U.S. Department of Energy OCRWM Records Management purposes only and should not be used when ordering the publication. 